\title{
Assessment of Appalachian Basin Oil and Gas Resources: Carboniferous Coal-bed Gas Total Petroleum System
}

By Robert C. Milici

Chapter G.1 of

Coal and Petroleum Resources in the Appalachian Basin:

Distribution, Geologic Framework, and Geochemical Character

Edited by Leslie F. Ruppert and Robert T. Ryder

Supersedes USGS Open-File Report 2004-1272

Professional Paper 1708 
Suggested citation:

Milici, R.C., 2014, Assessment of Appalachian basin oil and gas resources; Carboniferous Coal-bed Gas Total Petroleum System, chap. G.1 of Ruppert, L.F., and Ryder, R.T., eds., Coal and petroleum resources in the Appalachian basin; Distribution, geologic framework, and geochemical character: U.S. Geological Survey Professional Paper 1708, 61 p., http://dx.doi.org/10.3133/pp1708G.1. (Chapter G.1 supersedes USGS Open-File Report 2004-1272.) 


\section{Contents}

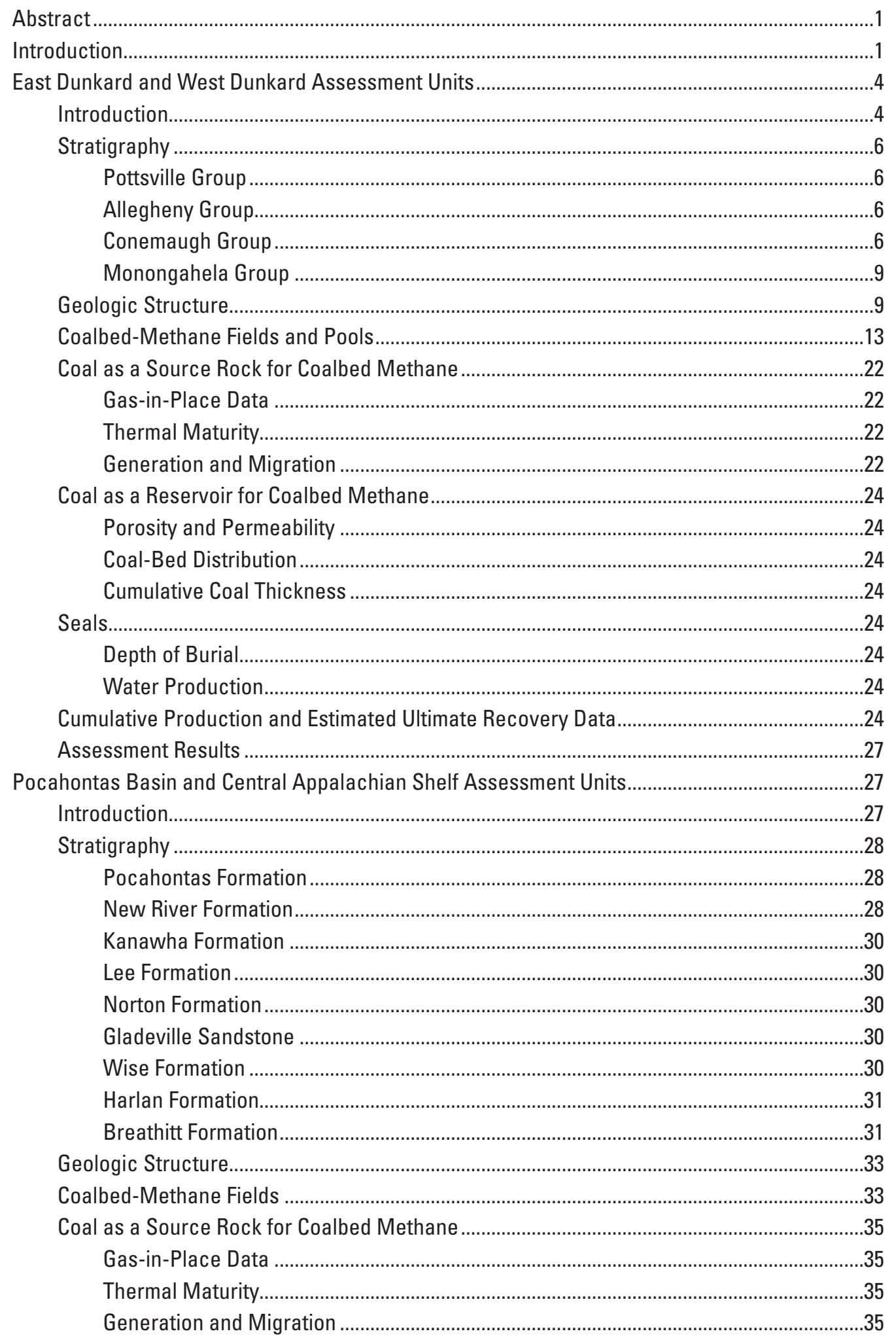


Coal as a Reservoir for Coalbed Methane..............................................................................

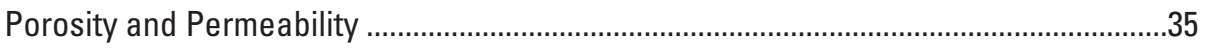

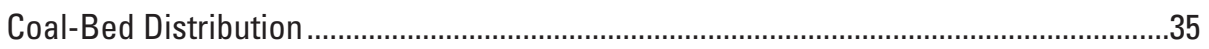

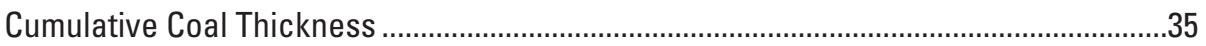

Seals

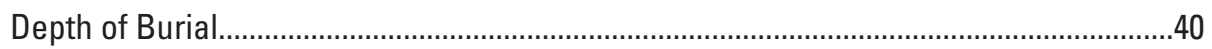

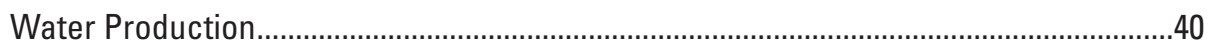

Cumulative Production and Estimated Ultimate Recovery Data ................................................40

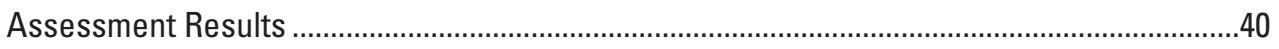

Appalachian Anthracite and Semi-Anthracite Assessment Unit: Pennsylvania

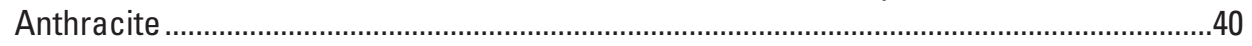

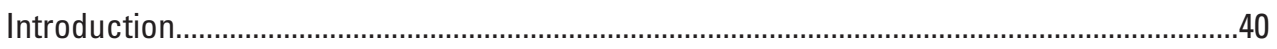

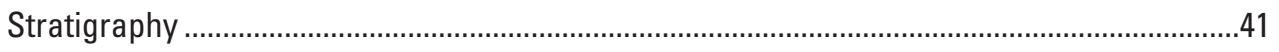

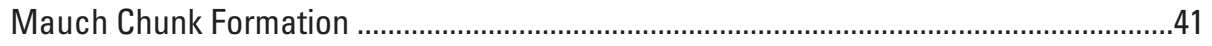

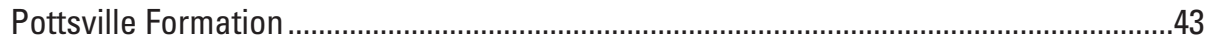

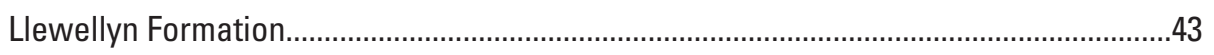

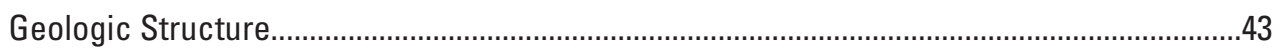

Coal as a Source Rock for Coalbed Methane .......................................................................

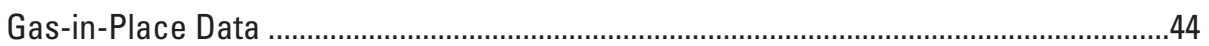

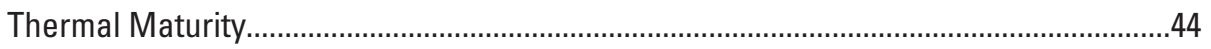

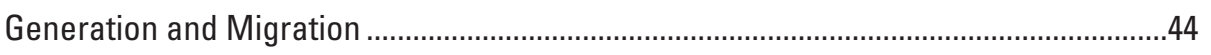

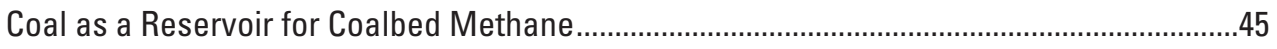

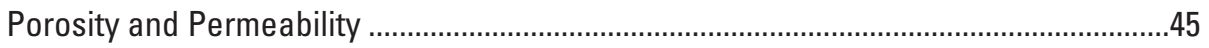

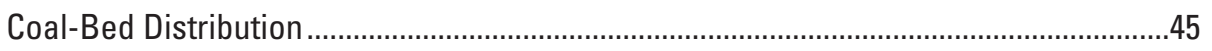

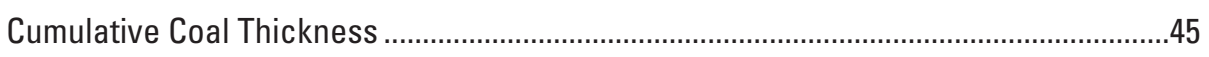

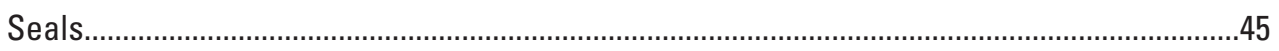

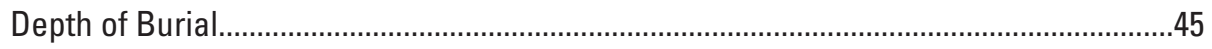

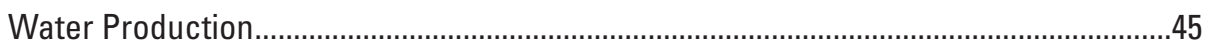

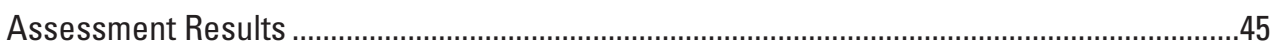

Appalachian Anthracite and Semi-Anthracite Assessment Unit: Virginia

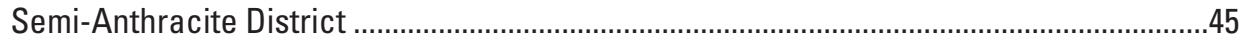

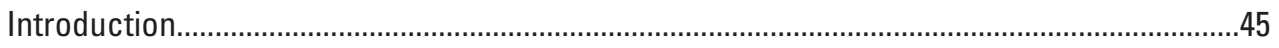

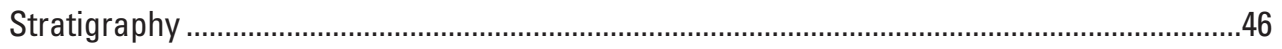

Cambrian Formations of the Pulaski Thrust Sheet.........................................................46

Mississippian Formations of the Footwall .................................................................47

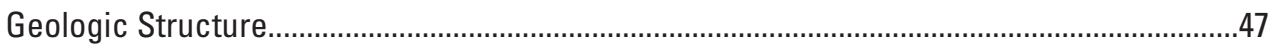

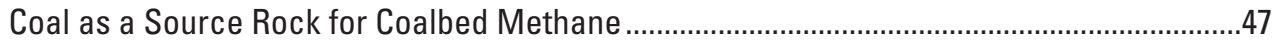

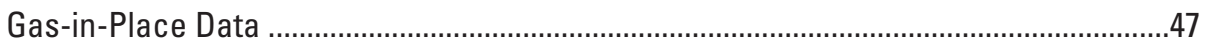

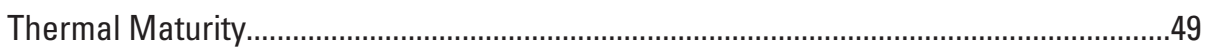

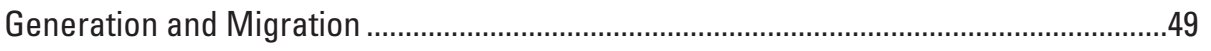

Coal as a Reservoir for Coalbed Methane......................................................................50

Porosity and Permeability .......................................................................................50

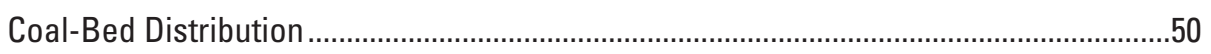

Cumulative Coal Thickness .................................................................................52

Seals 


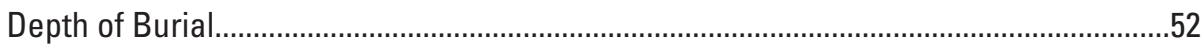

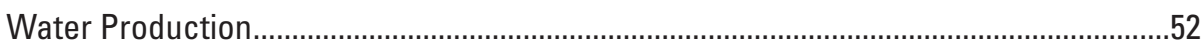

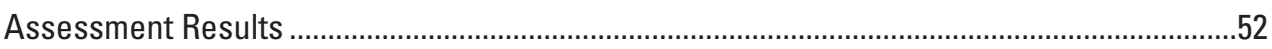

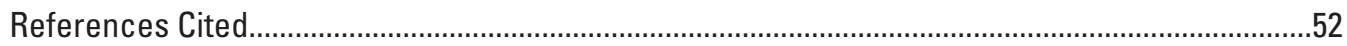

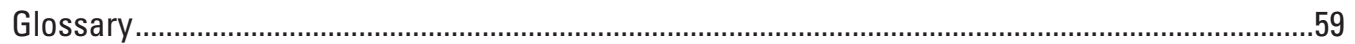

\section{Figures}

1. Maps of the central and southern parts of the Appalachian structural basin showing (A) oil and gas provinces and assessment units used by the U.S. Geological Survey (USGS) during the 2002 National Oil and Gas Assessment (Milici and others, 2003; Milici and Hatch, 2004) and (B) the Appalachian Plateaus and Allegheny structural front.

2. Map of the Carboniferous Coal-bed Gas Total Petroleum System and Minimum Petroleum System in the northern Appalachian basin coal region, showing the location of the East Dunkard (Folded) and West Dunkard (Unfolded) Assessment Units

3. Chart showing generalized stratigraphic nomenclature for Pennsylvanian and Permian units in the northern Appalachian basin coal region ..........................................

4. Chart showing major coal beds of the Dunkard basin ....................................................

5. Generalized stratigraphic column of the Pottsville and Allegheny Groups in Clearfield County and adjacent counties, Pennsylvania.................................................10

6. Cross section $A-A^{\prime}$ from Ohio County, W. Va., southeast to Garrett County, Md., showing the Allegheny Group

7. Cross section $B-B^{\prime}$ from Allegheny County, Pa., southeast to Allegany County, Md., showing the Allegheny Group

8. Generalized stratigraphic column of the Upper Pennsylvanian Monongahela Group, showing major coal beds and informal stratigraphic units present in Pennsylvania .....

9. Generalized cross section $C-C^{\prime}$ from Guernsey County, Ohio, east to Fayette County, Pa., showing units overlying the Pittsburgh coal bed.

10. Map showing location of coalbed-methane wells with respect to major coal beds in the northern Appalachian basin coal region and the vitrinite reflectance isoline of 0.8 percent...

11. Structure-contour map of the top of the Upper Freeport coal bed in the northern Appalachian basin coal region..

12. Map showing major coalbed-methane fields and CBM wells of the northern Appalachian basin coal region with respect to the vitrinite reflectance isoline of 0.8 percent

13. Map showing a direct measurement of gas-in-place content in coal beds for selected counties in the northern Appalachian basin coal region

14. Map showing cumulative production of coalbed methane for selected counties in the northern Appalachian basin coal region by $2005 .$.

15. Events chart for thermogenic coalbed methane in the Carboniferous Coal-bed Gas Total Petroleum System in the Appalachian Basin Province.

16. Map of the central Appalachian basin coal region showing the Pocahontas Basin and Central Appalachian Shelf Assessment Units, major coalbed-methane fields, and the Pocahontas No. 3 coal bed... 
17. Chart showing generalized stratigraphic nomenclature for Pennsylvanian and

Permian units in the central Appalachian basin coal region.

18. Chart showing stratigraphic nomenclature for Lower Pennsylvanian formations, sandstones, and selected coal beds in coalbed-methane fields in the Pocahontas Basin Assessment Unit of southwestern Virginia and adjacent West Virginia ..

19. Map showing major structural elements of the central and southern parts of the Appalachian structural basin.

20. Map showing a direct measurement of gas-in-place content in coal beds for selected counties in and near the Central Appalachian Shelf and Pocahontas Basin Assessment Units.

21. Map showing thermal maturation data for the central Appalachian basin coal region

22. Map showing the extent and apparent rank of the Pocahontas No. 3 coal bed in Virginia and West Virginia based on 125 analyses.

23. Map showing the extent and apparent rank of the Fire Clay coal zone in Kentucky, Virginia, and West Virginia based on 55 analyses.

24. Map showing location and generalized geology of the Pennsylvania Anthracite region

25. Generalized columnar sections showing the names of coal beds, the average thickness of each coal in feet, and the intervals between coal beds in the Pennsylvania Anthracite fields.

26. Map showing location and generalized geology of the Virginia semianthracite district.

27. Map of the central part of the Virginia semianthracite district, showing locations of Virginia Division of Mineral Resources coreholes and commercial coalbed-methane test coreholes near Radford, Va.

\section{Tables}

1. Cumulative production of coalbed methane (CBM) from the Appalachian basin by county

2. Coalbed-methane (CBM) fields and pools in the Dunkard basin, Pennsylvania and West Virginia

3. Estimates of total undiscovered coalbed-methane resources of the Carboniferous Coal-bed Gas Total Petroleum System

4. Gas-in-place data for the Northern and Southern fields of the Pennsylvania Anthracite region

5. Stratigraphic nomenclature of the Price Mountain area in the Virginia semianthracite district.

6. Locations of three coreholes drilled in the Virginia semianthracite district in Montgomery County by the Virginia Division of Mineral Resources in 1982 in a search for coalbed methane

7. Desorption data from the Merrimac and Langhorne coals in two coreholes drilled in the Virginia semianthracite district in Montgomery County

8. Location data for commercial wells drilled in the Virginia semianthracite district in Pulaski County.

9. Results of six commercial coalbed-methane (CBM) test wells drilled in the Virginia semianthracite district in Pulaski County 


\section{Conversion Factors}

\begin{tabular}{|c|c|c|}
\hline Multiply & By & To obtain \\
\hline \multicolumn{3}{|c|}{ Length } \\
\hline inch (in.) & 2.54 & centimeter $(\mathrm{cm})$ \\
\hline foot $(\mathrm{ft})$ & 0.3048 & $\operatorname{meter}(\mathrm{m})$ \\
\hline mile (mi) & 1.609 & kilometer $(\mathrm{km})$ \\
\hline \multicolumn{3}{|c|}{ Area } \\
\hline acre & 0.4047 & hectare (ha) \\
\hline \multicolumn{3}{|c|}{ Volume } \\
\hline gallon (gal) & 0.003785 & cubic meter $\left(\mathrm{m}^{3}\right)$ \\
\hline cubic foot $\left(\mathrm{ft}^{3}\right)$ & 0.02832 & cubic meter $\left(\mathrm{m}^{3}\right)$ \\
\hline barrel (bbl; 42 U.S. gallons) & 0.1590 & cubic meter $\left(\mathrm{m}^{3}\right)$ \\
\hline cubic centimeter $\left(\mathrm{cm}^{3}\right)$ & 0.06102 & cubic inch $\left(\mathrm{in}^{3}\right)$ \\
\hline \multicolumn{3}{|c|}{ Mass } \\
\hline $\begin{array}{l}\text { short ton }(2,000 \text { pounds } \\
\text { avoirdupois })\end{array}$ & 0.9072 & $\begin{array}{l}\text { metric ton (megagram }=1,000 \\
\text { kilograms) }\end{array}$ \\
\hline $\operatorname{gram}(\mathrm{g})$ & 0.03527 & ounce, avoirdupois (oz) \\
\hline \multicolumn{3}{|c|}{ Gas-in-place content of coal bed } \\
\hline cubic foot per short ton (CF/ton) & 0.03122 & cubic meter per metric ton $\left(\mathrm{m}^{3} / \mathrm{t}\right)$ \\
\hline \multicolumn{3}{|c|}{ Volume of gas per unit mass } \\
\hline $\begin{array}{l}\text { cubic centimeter per gram } \\
\left(\mathrm{cm}^{3} / \mathrm{g}\right)\end{array}$ & 0.016018 & $\begin{array}{l}\text { cubic foot per pound avoirdupois } \\
\left(\mathrm{ft}^{3} / \mathrm{lb}\right)\end{array}$ \\
\hline \multicolumn{3}{|c|}{ Calorific value } \\
\hline British thermal unit (Btu) & $1,055.056$ & joule $(\mathrm{J})$ \\
\hline $\begin{array}{l}\text { British thermal unit per pound } \\
\text { avoirdupois }(\mathrm{Btu} / \mathrm{lb})\end{array}$ & 2,326 & joule per kilogram (J/kg) \\
\hline
\end{tabular}

Temperature in degrees Celsius $\left({ }^{\circ} \mathrm{C}\right)$ may be converted to degrees Fahrenheit $\left({ }^{\circ} \mathrm{F}\right)$ as follows:

${ }^{\circ} \mathrm{F}=\left(1.8 x^{\circ} \mathrm{C}\right)+32$

Temperature in degrees Fahrenheit $\left({ }^{\circ} \mathrm{F}\right)$ may be converted to degrees Celsius $\left({ }^{\circ} \mathrm{C}\right)$ as follows:

${ }^{\circ} \mathrm{C}=\left({ }^{\circ} \mathrm{F}-32\right) / 1.8$

\section{Letter Symbols for Units of Measure Definitions}

$\begin{array}{ll}\text { BCF } & \text { billion cubic feet }\left(\mathrm{ft}^{3} \times 10^{9}\right) \\ \text { bst } & \text { billion short tons } \\ \text { CF/ton } & \text { cubic feet per short ton } \\ \text { MCF } & \text { thousand cubic feet }\left(\mathrm{ft}^{3} \times 10^{3}\right) \\ \text { MCF/acre } & \text { thousand cubic feet per acre } \\ \text { MCF/day } & \text { thousand cubic feet per day } \\ \text { MMCF } & \text { million cubic feet }\left(\mathrm{ft}^{3} \times 10^{6}\right) \\ \text { TCF } & \text { trillion cubic feet }\left(\mathrm{ft}^{3} \times 10^{12}\right)\end{array}$

[Also see the Glossary following the References Cited]

thousands $=10^{3}$

millions $=10^{6}$

billions $\quad=10^{9}$

trillions $\quad=10^{12}$ 



\title{
Assessment of Appalachian Basin Oil and Gas Resources: Carboniferous Coal-bed Gas Total Petroleum System
}

\author{
By Robert C. Milici'
}

\section{Abstract}

The Carboniferous Coal-bed Gas Total Petroleum System, which lies within the central and southern Appalachian basin, consists of the following five assessment units (AUs): (1) the Pocahontas Basin AU in southern West Virginia, eastern Kentucky, and southwestern Virginia; (2) the Central Appalachian Shelf AU in Tennessee, eastern Kentucky, and southern West Virginia; (3) the East Dunkard (Folded) AU in western Pennsylvania and northern West Virginia; (4) the West Dunkard (Unfolded) AU in Ohio and adjacent parts of Pennsylvania and West Virginia; and (5) the Appalachian Anthracite and Semi-Anthracite AU in Pennsylvania and Virginia. Only two of these assessment units were assessed quantitatively by the U.S. Geological Survey (USGS) in the National Oil and Gas Assessment in 2002. The USGS estimated the Pocahontas Basin AU and the East Dunkard (Folded) AU to contain a mean of about 3.6 and 4.8 trillion cubic feet (TCF) of undiscovered, technically recoverable gas, respectively.

In general, the coal beds of the Carboniferous Coal-bed Gas Total Petroleum System (which are both the source rock and the reservoir) were deposited as peat together with their associated sedimentary strata in Mississippian and Pennsylvanian (Carboniferous) time. The generation of biogenic (microbial) gas probably began as soon as the peat deposits formed. Microbial gas generation is probably occurring at present to some degree throughout the Appalachian basin, wherever the coal beds are relatively shallow and wet. As a result of significant depth of burial, compaction, and coalification during the late Paleozoic and early Mesozoic, the coal beds were heated sufficiently to generate thermogenic gas (coalbed methane) in the eastern part of the Appalachian basin.

Trap formation began with the deposition of the peat deposits during the Mississippian and continued into the Late Pennsylvanian and Permian, when strata of the Appalachian Plateaus were deformed during the Alleghanian orogeny. The seals are the connate waters that occupy fractures and larger pore spaces within the coal beds, as well as the fine-grained,

${ }^{1}$ U.S. Geological Survey, Reston, Va. siliciclastic sedimentary strata that are intercalated with the coal. The critical moment for the petroleum system occurred during the Alleghanian orogeny, when deformation resulted in the geologic structures in the eastern part of the Appalachian basin that enhanced fracture porosity within the coal beds. In places, burial by thrust sheets (thrust loading) in the Valley and Ridge physiographic province may have resulted in the additional generation of thermogenic coalbed methane in the Pennsylvania Anthracite region and in the semianthracite deposits of Virginia and West Virginia, although other explanations have been offered.

\section{Introduction}

Study area and scope of report. - Coalbed methane (CBM) occurs in coal beds of Mississippian and Pennsylvanian (Carboniferous) age in the northern, central and southern Appalachian basin coal regions (fig. 1A,B), which extend almost continuously from Pennsylvania southward to Alabama (Attanasi, 1998; Lyons, 1998; Markowski, 1998; Nolde and Spears, 1998; Pashin and Groshong, 1998). These three coal regions occur within the southern and central parts of the Appalachian structural basin. The northern part of the Appalachian structural basin extends from New York City to the Gulf of St. Lawrence (Rodgers, 1949, 1970). Because the northern Appalachian structural basin contains little coal, it is not discussed in this report.

The central and southern parts of the Appalachian basin contain three significant structural subbasins: (1) the Dunkard basin in Pennsylvania, Ohio, and northern West Virginia; (2) the Pocahontas basin in southern West Virginia, eastern Kentucky, and southwestern Virginia; and (3) the Black Warrior basin in Alabama. Each subbasin is within one of the three Appalachian basin coal regions defined by the U.S. Geological Survey (USGS) in the 2000 resource assessment of selected coal beds and zones (Northern and Central Appalachian Basin Coal Regions Assessment Team, 2001). Although details vary considerably, the overall stratigraphic framework of Carboniferous strata within the Appalachian basin coal regions is remarkably similar from one end to the other. 


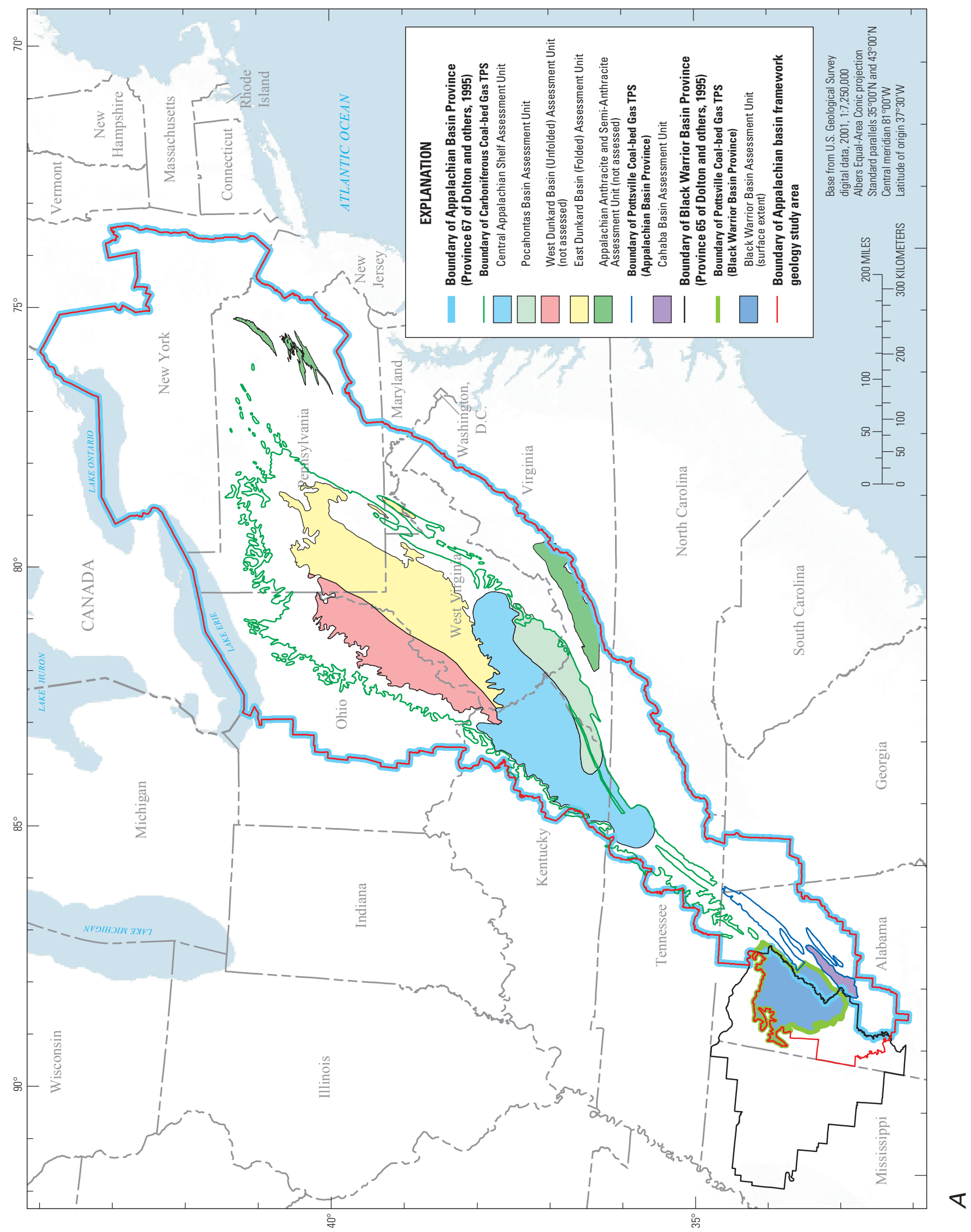


During the 2002 National Oil and Gas Assessment (NOGA), the USGS defined two assessment provinces that encompassed the southern and central parts of the Appalachian basin: the Appalachian Basin Province, which stretches from New York State to Alabama, and the Black Warrior Basin Province in Alabama and Mississippi. By far, most of the coalbed methane produced in the Appalachian basin has come from the Black Warrior Basin Province. During the 2002 assessment, the USGS assessed the hydrocarbon resources of the Black Warrior Basin Province separately from the resources in the remainder of the Appalachian basin; the discussion in this report is restricted almost entirely to the Appalachian Basin Province as follows: CBM resources in the bituminous coal regions in the Dunkard and Pocahontas basins and potential CBM resources in the anthracite and semianthracite regions in the Valley and Ridge Province in Pennsylvania and Virginia (fig. 1A,B).

For assessment of coalbed methane, the Appalachian Basin Province was divided into two total petroleum systems: the Carboniferous Coal-bed Gas Total Petroleum System and the Pottsville Coal-bed Gas Total Petroleum System. The relation between total petroleum systems and assessment units is shown in figure $1 A$. Terms such as "total petroleum system (TPS)" (Magoon, 1988), "minimum petroleum system (MPS)," and "assessment unit (AU)" are defined in the glossary following the "References Cited."

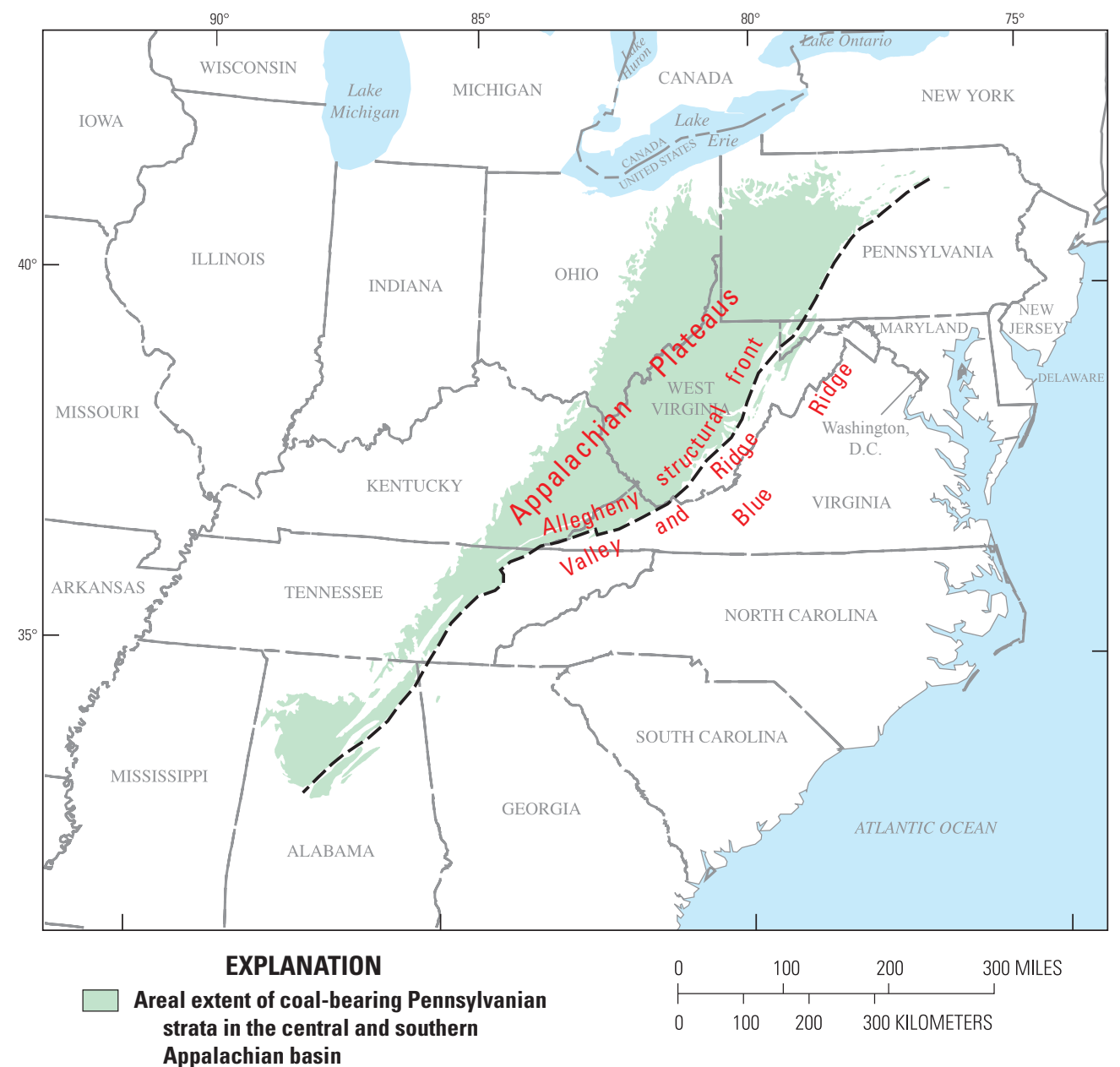

$B$

Figure 1 (facing page and this page). Maps of the central and southern parts of the Appalachian structural basin showing $(A)$ oil and gas provinces and assessment units used by the U.S. Geological Survey (USGS) during the 2002 National Oil and Gas Assessment (Milici and others, 2003; Milici and Hatch, 2004) and (B) the Appalachian Plateaus and Allegheny structural front. The focus in this report is on the coalbed-methane resources of the Carboniferous Coal-bed Gas Total Petroleum System in the Appalachian Basin Province. 
The results of the 2002 National Oil and Gas Assessment for the Appalachian Basin Province and the Black Warrior Basin Province were summarized in two USGS Fact Sheets (Milici and others, 2003; Milici and Hatch, 2004). USGS Open-File Report 2004-1272 (Milici, 2004) described the CBM resources of the Carboniferous Coal-bed Gas Total Petroleum System.

This report is an edited version of USGS Open-File Report 2004-1272 and supersedes it. The five assessment units are described in four main sections of this report: (1) East Dunkard and West Dunkard Assessment Units, (2) Pocahontas Basin and Central Appalachian Shelf Assessment Units, (3) Appalachian Anthracite and Semi-Anthracite Assessment Unit: Pennsylvania Anthracite, and (4) Appalachian Anthracite and Semi-Anthracite Assessment Unit: Virginia Semi-Anthracite.

Assessment data. - Of the five assessment units discussed in this report, only the Pocahontas Basin AU and the East Dunkard (Folded) AU were assessed quantitatively by the USGS in 2002. The USGS estimated the Pocahontas Basin AU and the East Dunkard (Folded) AU to contain a mean of about 3.6 and 4.8 trillion cubic feet (TCF) of undiscovered, technically recoverable gas, respectively (R.C. Milici and others, 2003). The assessment focused on resources likely to be found in a 30 -year timeframe. The principal factors considered during the USGS 2002 assessment of CBM in the Appalachian Basin Province were as follows: (1) available gas-in-place data, (2) thermal maturation data, (3) timing of generation and migration of CBM, (4) porosity and permeability, (5) known distribution of major coal beds, (6) cumulative coal thickness, (7) depth of burial, (8) water production, and (9) cumulative production data.

In general, CBM accumulations are assessed as continuous accumulations and, for assessment purposes, are not designated as discrete fields. Nevertheless, in some areas, the economic viability of an accumulation may be enhanced by local stratigraphy or geologic structure and may result in a drilling entity that could be defined as a field, even though its boundaries are gradational with surrounding areas that contain gas. For the most part, CBM fields are designated by State regulatory agencies more for administrative and regulatory convenience than because of their geologic features.

CBM production through 2006.-Methane degasification in advance of underground mining commenced in the early 1970s in the Black Warrior basin and in the late 1970s and early 1980s in the Pocahontas basin. The goals were to prevent explosions and to improve mine safety conditions in deeply buried coal beds. Vertical ventilation holes were drilled into the Blue Creek coal bed in Alabama and the Pocahontas No. 3 coal bed in Virginia. When the practice began, gas was vented into the atmosphere after being produced either (1) from coal beds in advance of mining or (2) from gob wells drilled into old works after mining. Where gas was abundant enough to constitute a resource and when ownership issues were resolved, commercial production of CBM commenced in Alabama in 1980 (Pashin and Hinkle, 1997) and in Virginia in 1988 (Nolde and Spears, 1998). CBM production from the Pocahontas No. 3 coal bed began in southern West Virginia in 1995 (Avary, 2004).

By 2002, annual production of CBM in the Black Warrior basin of Alabama had increased to more than 110 billion cubic feet (BCF) of gas from 3,357 wells (Alabama State Oil and Gas Board, 2002). In the part of the Pocahontas basin in Virginia and southern West Virginia, 2,359 wells yielded $66 \mathrm{BCF}$ of CBM (Avary, 2004; Virginia Center for Coal and Energy Research, 2004); production was very small in the part of the Pocahontas basin in Kentucky (Kentucky Division of Oil and Gas Conservation, 2004). In the eastern part of the Dunkard basin in Pennsylvania and northern West Virginia, 249 wells yielded 1.4 BCF of CBM (A.K. Markowski, Pennsylvania Bureau of Topographic and Geologic Survey, written commun., 2003; Avary, 2004).

As of 2003, cumulative CBM production had reached about 1.5 trillion cubic feet (TCF) from the Black Warrior basin (table 1). As of 2006, cumulative CBM production had reached 754 BCF from the Pocahontas basin; as of 2005, it had reached 17.4 BCF from the Dunkard basin (table 1).

In the Appalachian basin, most of the gas produced from coal beds is methane, and small amounts of other gases may be present. Gob gas produced from previously mined areas (coal-mine methane) commonly contains relatively large amounts of gaseous impurities (such as nitrogen, oxygen, and carbon dioxide) from mine atmospheres. Markowski (2001) provided results of numerous analyses of gas produced from both conventional CBM well completions and gob wells in Pennsylvania.

\section{East Dunkard and West Dunkard Assessment Units}

\section{Introduction}

The East Dunkard and West Dunkard Assessment Units are entirely within the Dunkard basin, which occupies much of the northern part of the Appalachian Basin Province in Pennsylvania, eastern Ohio, and northern West Virginia (fig. 2). The Dunkard basin is defined generally by the cropline of the base of the Pennsylvanian Conemaugh Group and is about 300 miles (mi) long (parallel to the Appalachian regional strike) and is 100 mi wide. The East Dunkard AU is in the folded part of the Dunkard basin, and its coalbed-methane resources were assessed quantitatively by the USGS in 2002 . The West Dunkard AU is in the unfolded part of the basin, and its CBM resources have not been assessed.

The former U.S. Bureau of Mines recognized both the safety problems and the economic potential of coalbed methane released by coal mines in the Upper and Lower Freeport coal beds and the Upper, Middle, and Lower Kittanning coal beds in Indiana and Cambria Counties, Pa. (Iannacchione and 
Table 1. Cumulative production of coalbed methane (CBM) from the Appalachian basin, by county.

[Sources of data: Alabama State Oil and Gas Board (2004), Kentucky Division of Oil and Gas Conservation (2004), Pennsylvania Bureau of Topographic and Geologic Survey (2006), Virginia Center for Coal and Energy Research (2004), Virginia Division of Gas and Oil (2007), and West Virginia Geological and Economic Survey (2006). Terms used: MCF, thousand cubic feet; ND, no data]

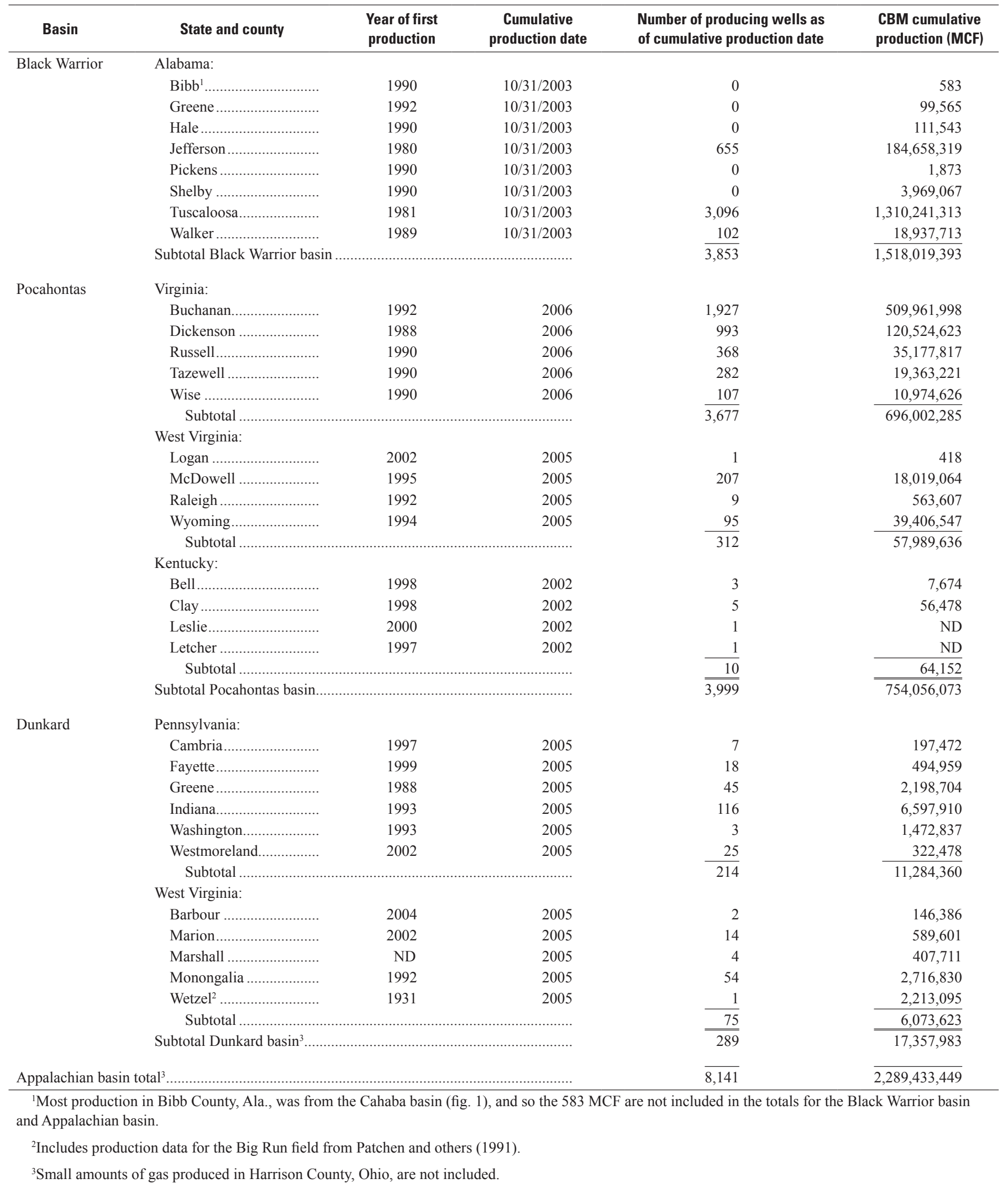


Puglio, 1979; Puglio and Iannacchione, 1979). In 1976, three mines in Cambria County produced an average of 2.6, 2.7, and 3.1 thousand cubic feet per day (MCF/day) of CBM (Iannacchione and Puglio, 1979, table 1). In Indiana County, a CBM test in the Lower Kittanning coal bed yielded a gas content of 352 cubic feet per short ton ( $\mathrm{CF} /$ ton) under ambient conditions. At the time, that was one of the highest measurements ever from a coal bed in the bituminous coal fields of Pennsylvania (Puglio and Iannacchione, 1979, table 8).

Wolfe (1997) reported that a mine vent in Harrison County, Ohio, had produced up to $500 \mathrm{MCF} /$ day of gas having a methane content of 91 percent. In 1998, the vent produced about 56.5 million cubic feet (MMCF) of gas for local use in 6 months (Steve O'Pritza, Ohio Division of Oil and Gas, oral commun., June 2000).

Figure 2 illustrates the extent of the Carboniferous Coalbed Gas Total Petroleum System in the northern Appalachian basin coal region and the extent of the Carboniferous Coal-bed Gas Minimum Petroleum System (the area in the larger system in which the petroleum system is demonstrated to be active by the occurrence or production of hydrocarbons). The cropline of the base of the Conemaugh Group in figure 2 shows the extent of the area where Allegheny Group coal beds are buried deeply enough (more than 500 feet $(\mathrm{ft})$ ) beneath the Conemaugh Group to be considered as potential sources and reservoirs for CBM. Relatively small amounts (shows) of coal-bed gas and of coal-mine methane (most likely of microbial origin) (Laughrey and Baldassare, 1998) occur well beyond the area selected for the minimum petroleum system, which is the area in which most of the methane produced is probably thermogenic (where the vitrinite reflectance (expressed as a percentage, $\% R_{o}$ ) is greater than or equal to $0.8 \% R_{0}$ ).

The stratigraphic nomenclature for the major groupings of Pennsylvanian strata in the northern Appalachian basin coal region is shown in figure 3 , and coal-bed nomenclature for the Dunkard basin is presented in figure 4 . The principal coal beds targeted for CBM exploration in this region are within the Monongahela and Allegheny Groups (figs. 5, 6, 7, 8, and 9). Although all of the major coal beds are extensively mined along their outcrop, much unmined coal remains in the deeper part of the Dunkard basin.

\section{Stratigraphy}

\section{Pottsville Group}

The Pottsville Group (or Formation) consists of the coal-bearing siliciclastic strata that are between older Mississippian strata and the top of the Homewood sandstone or the base of the Brookville coal bed in the Allegheny Formation, where present (fig. 3). The basal contact of the Pottsville with underlying strata is unconformable (fig. 5); accordingly, the thickness of the Pottsville varies greatly, generally from about 20 to $350 \mathrm{ft}$ (Arkle and others, 1979; Collins, 1979; Edmunds and others, 1999). In Ohio and West Virginia, the Pottsville consists primarily of conglomerate, sandstone, siltstone, and shale and contains a few thin and irregular coal beds. Marine limestone, shale, and calcareous ironstone are common, although they are present in relatively small amounts. In Pennsylvania, the Pottsville consists of two parts: (1) a lower sequence of conglomerate, sandstone, and shale, with minor amounts of coal, and (2) an upper succession that is composed of the Mercer coal zone and shale and the overlying Homewood sandstone (fig. 5).

\section{Allegheny Group}

The Allegheny Group (or Formation) includes all strata between the base of the Brookville coal bed and the top of the Upper Freeport coal bed (figs. 3 and 5) (Arkle and others, 1979; Collins, 1979; Edmunds and others, 1999). In general, the group is an anastomosing mixture of sandstone, siltstone, shale and claystone, and coal (fig. 5) that ranges in thickness from about 100 to $330 \mathrm{ft}$. Nevertheless, some coals, marine shales, and limestones are very widespread (figs. 6 and 7) (Edmunds and others, 1999). The lower half of the group contains several marine or brackish-water units, such as the Vanport Limestone; the upper part of the group is entirely nonmarine.

There are six major coal beds and coal zones within the Allegheny Group, and they make the group an important target for CBM development (figs. 4, 5, 6, and 7). In ascending order, these include the Brookville coal bed, the Clarion coal bed, the Lower Kittanning coal zone (Milici, Freeman, and others, 2001), the Middle Kittanning coal bed, the Upper Kittanning coal bed, the Lower Freeport coal bed, and the Upper Freeport coal bed (Ruppert and others, 2001). Of these, the Upper Freeport and the Lower Kittanning are the second and third most important coal units in Pennsylvania (behind the Pittsburgh) in terms of potential coal resources (Edmunds and others, 1999).

\section{Conemaugh Group}

The Conemaugh Group consists of those strata between the top of the Upper Freeport coal bed and the base of the Pittsburgh coal bed (fig. 3). In Pennsylvania, the Conemaugh Group is divided into the Glenshaw Formation at the base and the Casselman Formation at the top (fig. 3) (Flint, 1965). The boundary between these two units is the top of the marine Ames Limestone. The Conemaugh Group contains several named sandstone formations (or members), including the Mahoning sandstone at the base of the Glenshaw Formation. The thickness of the Conemaugh Group averages about $400 \mathrm{ft}$ in Ohio, and it ranges from $450 \mathrm{ft}$ on the Ohio River in West Virginia to $520 \mathrm{ft}$ in Washington County, Pa., and then to $890 \mathrm{ft}$ in Somerset County, Pa. (Arkle and others, 1979; Collins, 1979; Edmunds and others, 1999). 


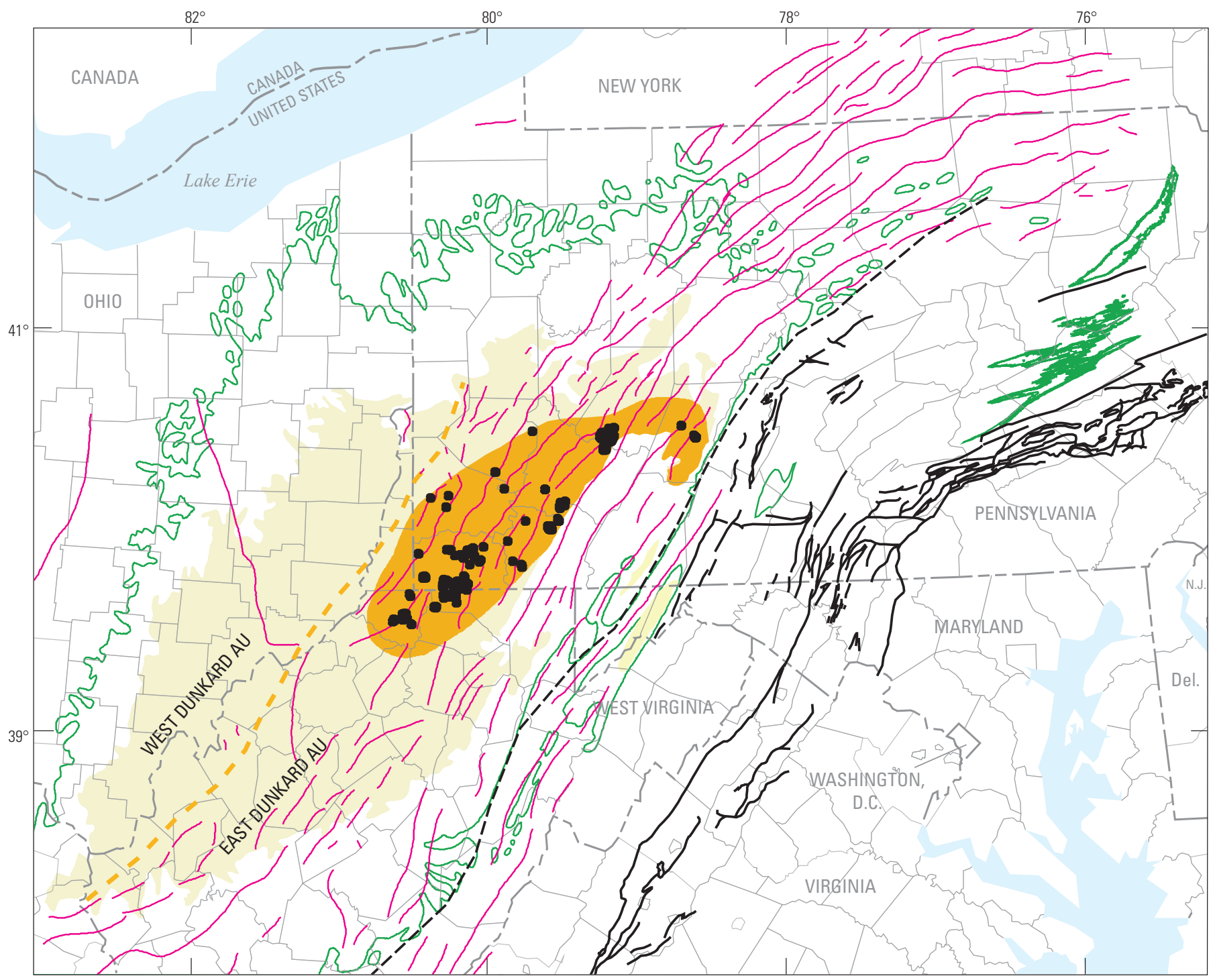

\section{EXPLANATION}

Carboniferous Coal-bed Gas Minimum Petroleum System

East Dunkard and West Dunkard Assessment Units-Outer boundary is generally defined by the cropline of the base of the Conemaugh Group

\section{Boundary of Carboniferous Coal-bed} Gas Total Petroleum System

$--=$ Boundary between the East Dunkard and West Dunkard Assessment Units

Figure 2. Map of the Carboniferous Coal-bed Gas Total Petroleum System and Minimum Petroleum System in the northern Appalachian basin coal region, showing the location of the East Dunkard (Folded) and West Dunkard (Unfolded) Assessment Units. The petroleum systems and assessment units were used by the U.S. Geological Survey during the 2002 National Oil and
Gas Assessment (Milici and others, 2003; Milici and Hatch, 2004). Locations of coalbed-methane wells from Markowski (2000) and Avary (2004). Thrust faults and traces of anticline axes from Cardwell and others (1968), Berg and others (1980), and Schruben and others (1994). Abbreviations are as follows: AU, Assessment Unit; Del., Delaware; N.J., New Jersey. 


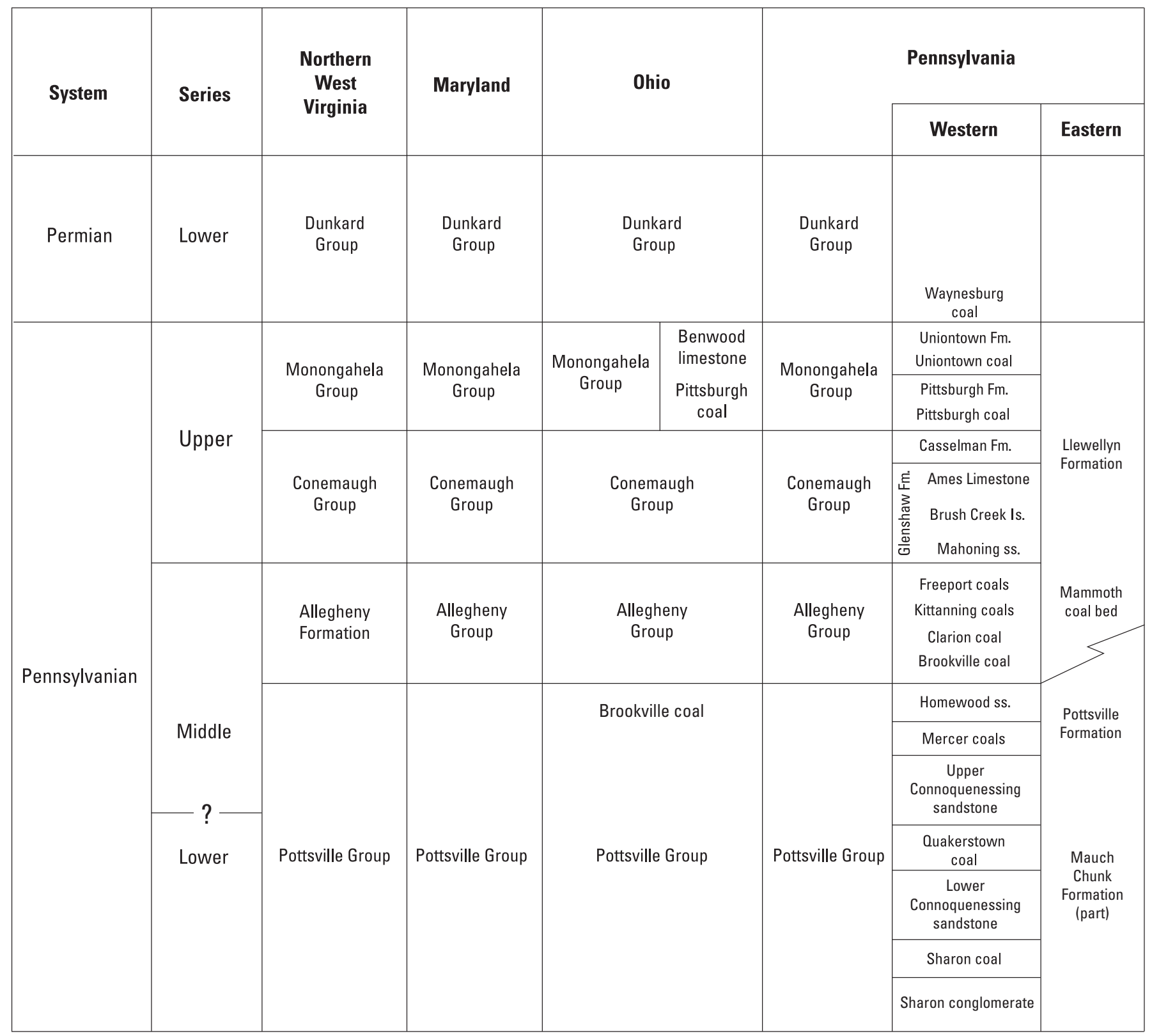

Figure 3. Chart showing generalized stratigraphic nomenclature for Pennsylvanian and Permian units in the northern Appalachian basin coal region. Some names vary from U.S. Geological Survey usage; rank terms (such as "conglomerate") for informal names are lowercased. Names are from Arkle and others (1979), Collins (1979), and Edmunds and others (1979, 1999). Abbreviations: cgl, conglomerate; Fm., Formation; Is., limestone; ss., sandstone.

The Conemaugh Group is dominated by siliciclastic strata, including claystone, shale, siltstone, and sandstone. In West Virginia, the Conemaugh consists primarily of red shale and mudstone, with some subgraywackes, thin limestones (both marine and nonmarine), and thin coal beds. Red beds are scattered throughout the stratigraphic section in Pennsylvania, and coal beds are generally thin and have little economic value. The Glenshaw Formation contains several marine units, and the overlying Casselman Formation is almost entirely nonmarine. In Ohio, the Conemaugh consists mostly of sandstone, siltstone, and shale. Thin coal beds are scattered throughout much of the section; as in Pennsylvania, marine zones are common in the lower part of the group, and red beds are abundant in the upper part of the section, which is generally nonmarine (Arkle and others, 1979; Collins, 1979; Edmunds and others, 1999).

Because the Upper Freeport coal bed and the overlying Mahoning sandstone are discontinuous or absent in the subsurface of southwestern Pennsylvania and northeastern West Virginia, Bruner and others (1995, republished in 1998), in their study of the CBM potential of the area, used the base of the Brush Creek marine zone (Brush Creek limestone of fig. 3) within the lower part of the Glenshaw Formation as their key marker horizon to define the top of their coal-bearing 


\begin{tabular}{|c|c|c|}
\hline System & Group & Coal bed or zone \\
\hline 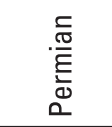 & Dunkard & Waynesburg \\
\hline \multirow{4}{*}{ 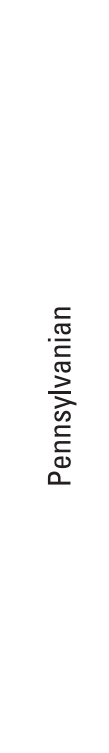 } & Monongahela & $\begin{array}{l}\text { Sewickley } \\
\text { Redstone } \\
\text { Pittsburgh }\end{array}$ \\
\hline & Conemaugh & $\begin{array}{c}\text { Bakerstown } \\
\text { Brush Creek } \\
\text { Mahoning }\end{array}$ \\
\hline & Allegheny & $\begin{array}{c}\text { Upper Freeport } \\
\text { Lower Freeport } \\
\text { Upper Kittanning } \\
\text { Middle Kittanning } \\
\text { Lower Kittanning } \\
\text { Clarion } \\
\text { Brookville }\end{array}$ \\
\hline & Pottsville & $\begin{array}{c}\text { Mercer } \\
\text { Quakerstown } \\
\text { Sharon }\end{array}$ \\
\hline
\end{tabular}

Figure 4. Chart showing major coal beds or zones of the Dunkard basin.

"operational" Allegheny Formation. In effect, this definition includes about $110 \mathrm{ft}$ of the Conemaugh Group, including the Mahoning sandstone and the Mahoning coal bed, within their operational Allegheny Formation. The operational Allegheny Formation of Bruner and others $(1995,1998)$ contains most of the target coal beds for CBM production in the northern Appalachian basin coal region.

\section{Monongahela Group}

The Monongahela Group extends from the base of the Pittsburgh coal bed upward to the Waynesburg coal bed (figs. 3, 8, and 9). Edmunds (1999) and Edmunds and others (1999) included the Waynesburg coal bed within the Dunkard Group in Pennsylvania, whereas Arkle and others (1979), Collins (1979), and Tewalt, Ruppert, Bragg, Carlton, and others (2001) placed the Waynesburg within the Monongahela Group in West Virginia and Ohio. The Monongahela Group averages about $250 \mathrm{ft}$ in thickness in Ohio. To the east, its thickness ranges from about $250 \mathrm{ft}$ on the Ohio River to $400 \mathrm{ft}$ in northcentral West Virginia and adjacent Pennsylvania (Arkle and others, 1979; Collins, 1979; Edmunds and others, 1999). In Pennsylvania, the Monongahela is divided into two formations: the Pittsburgh Formation at the base and the Uniontown Formation at the top. The boundary between the Pittsburgh and Uniontown Formations is placed at the base of the Uniontown coal bed (fig. 8) (Edmunds and others, 1999).
In Ohio, the Monongahela Group consists of generally nonmarine strata: (1) a gray facies composed of gray shale, limestone, and thick coal beds in the northern and central part of the basin, (2) a red facies composed of red and yellow mudstone and little coal in the southern part of the basin, and (3) a transitional facies of mixed lithologies in between (Collins, 1979). In West Virginia as in Ohio, coal-bearing gray shale, mudstone, and limestone in the northern part of West Virginia grade southwestward into red shale and mudstone that contain little coal and limestone (Arkle and others, 1979). In Pennsylvania, the Monongahela consists mostly of limestone, calcareous mudstone, shale, siltstone, and silty sandstone. The principal sandstone of the group, the Pittsburgh sandstone, overlies the Pittsburgh coal bed in the lower part of the section (fig. 9) (Edmunds and others, 1999).

Four coal beds, the Pittsburgh, Redstone, Sewickley, and Waynesburg, occur in the Monongahela Group in the northern part of the Dunkard basin. Of these, only the Pittsburgh is laterally persistent (fig. 10) and thick (4-12 ft) (Tewalt, Ruppert, Bragg, Carlton, and others, 2001); the others, although locally important, are not as thick and continuous as the Pittsburgh (Edmunds, 1999). In places, the Sewickley coal bed may be as thick as $6 \mathrm{ft}$ in southern Greene and Fayette Counties, Pa., and in nearby counties in West Virginia. The Pittsburgh and, locally, the Sewickley coal beds are among the principal targets for CBM exploration and development in this region. Where the Pittsburgh has been mined in southwestern Pennsylvania (fig. 10), wells drilled into mine breakdown (gob wells) produce coal-mine methane.

\section{Geologic Structure}

The East Dunkard and West Dunkard AUs are entirely within the Dunkard basin synclinorium (figs. $1 A$ and 2). The coal beds are both the source rocks and the reservoirs for methane. Depths to producing and potentially producing coal beds range from several hundred feet around the perimeter of the Dunkard basin to $2,000 \mathrm{ft}$ near its axis. Natural fractures related to regional geologic structure, as well as the more common cleats in coal, are essential for increasing the porosity and permeability of the coal beds to the extent required for commercial production of methane.

The East Dunkard AU is in the folded part of the synclinorium (fig. 2), where surficial folds in Pennsylvanian-age strata are the result of shortening above the regional subhorizontal décollement in the Silurian salt and (or) Ordovician shale formations (Frey, 1973). Structural intensity increases progressively to the east, to where the west-verging folds become increasingly asymmetrical; near the Allegheny structural front, their western limbs are steeply dipping to overturned. In general, deformation decreases progressively to the west as shortening above the décollement(s) decreases. There, the folds within the Appalachian Plateaus are broad and have relatively low amplitudes related to their extent, so that their limbs have relatively low dips (fig. 11) (Edmunds, 1999). 


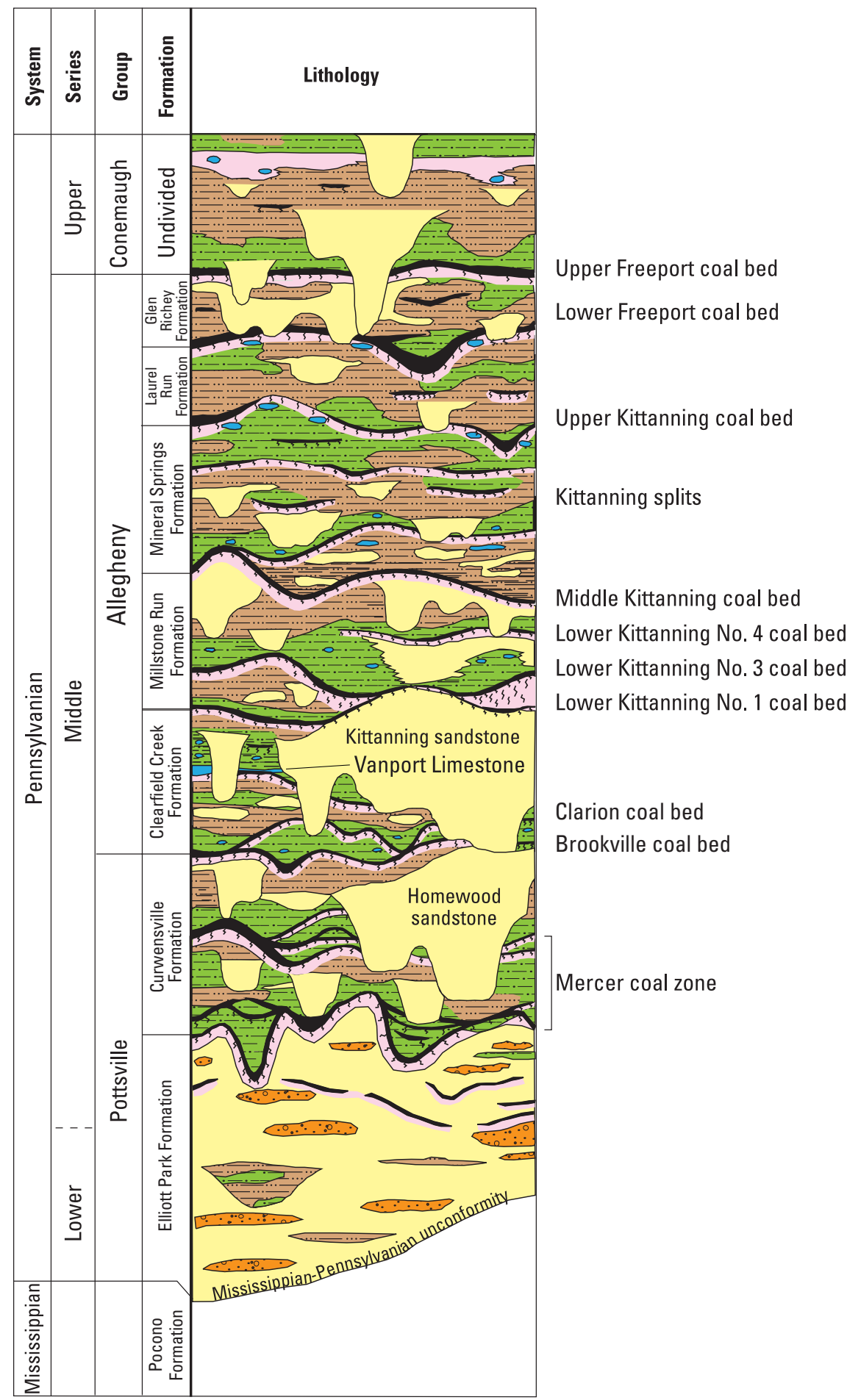

\section{EXPLANATION}
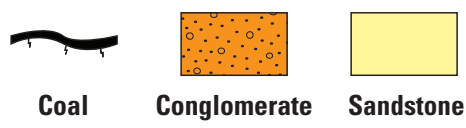

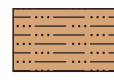

Shale and siltstone

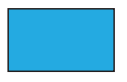

Limestone

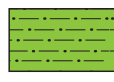

Shale

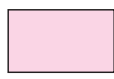

Claystone
Figure 5. Generalized stratigraphic column of the Pottsville and Allegheny Groups in Clearfield County and adjacent counties, Pennsylvania (from Milici, Freeman, and others, 2001, fig. 10, which was adapted from Glover and Bragonier, 1978). Adjacent counties include Indiana and Cambria (fig. 12). 


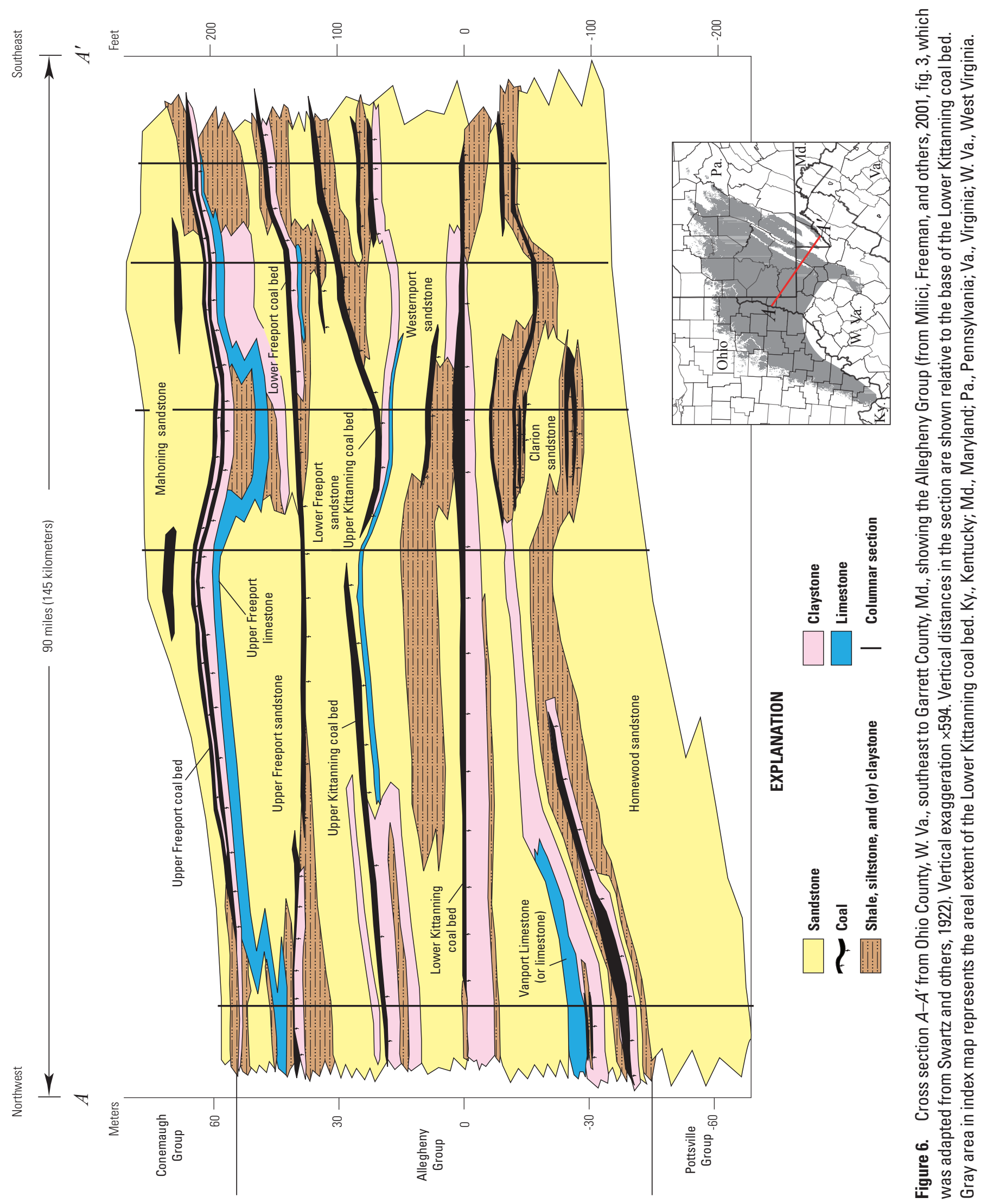




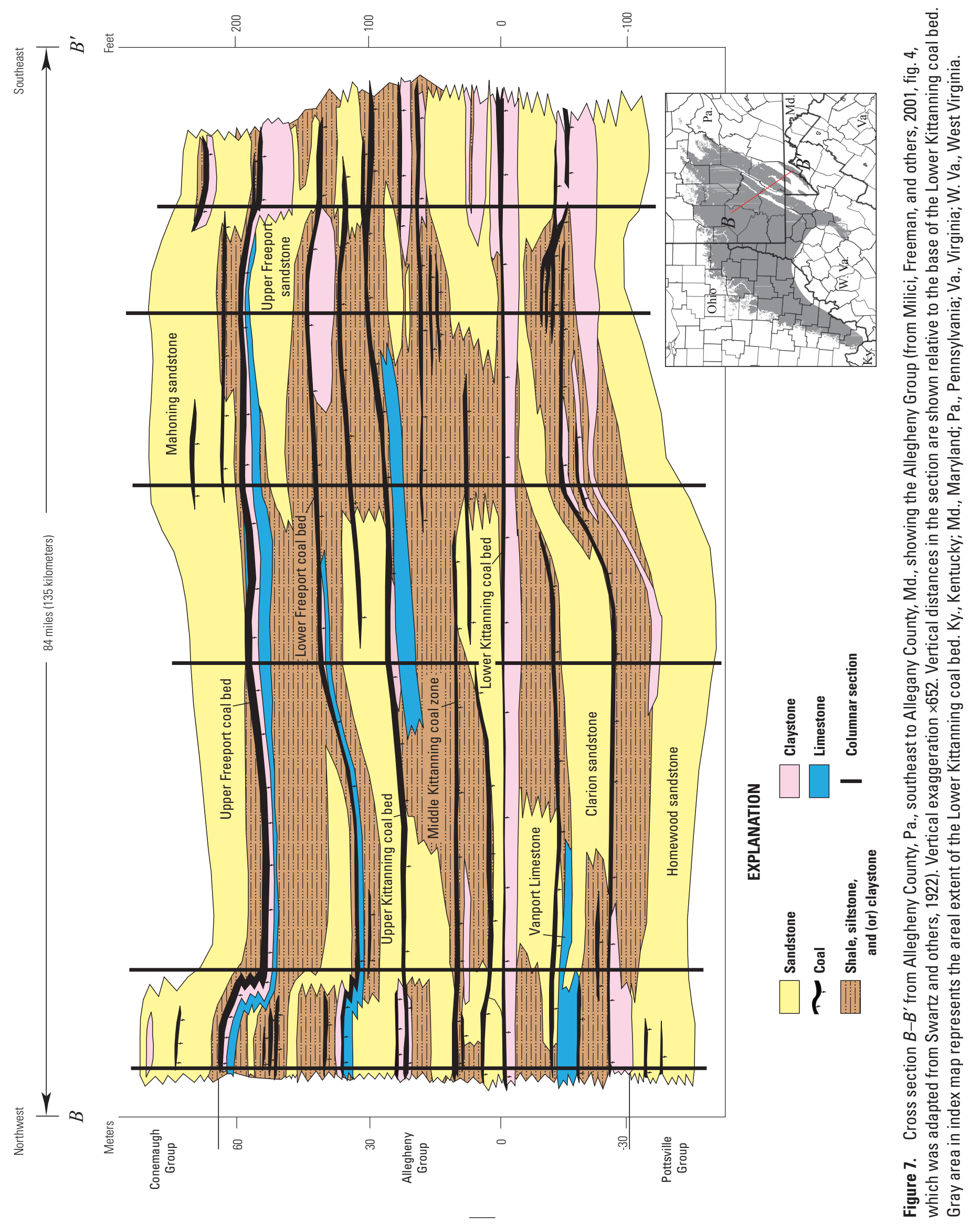




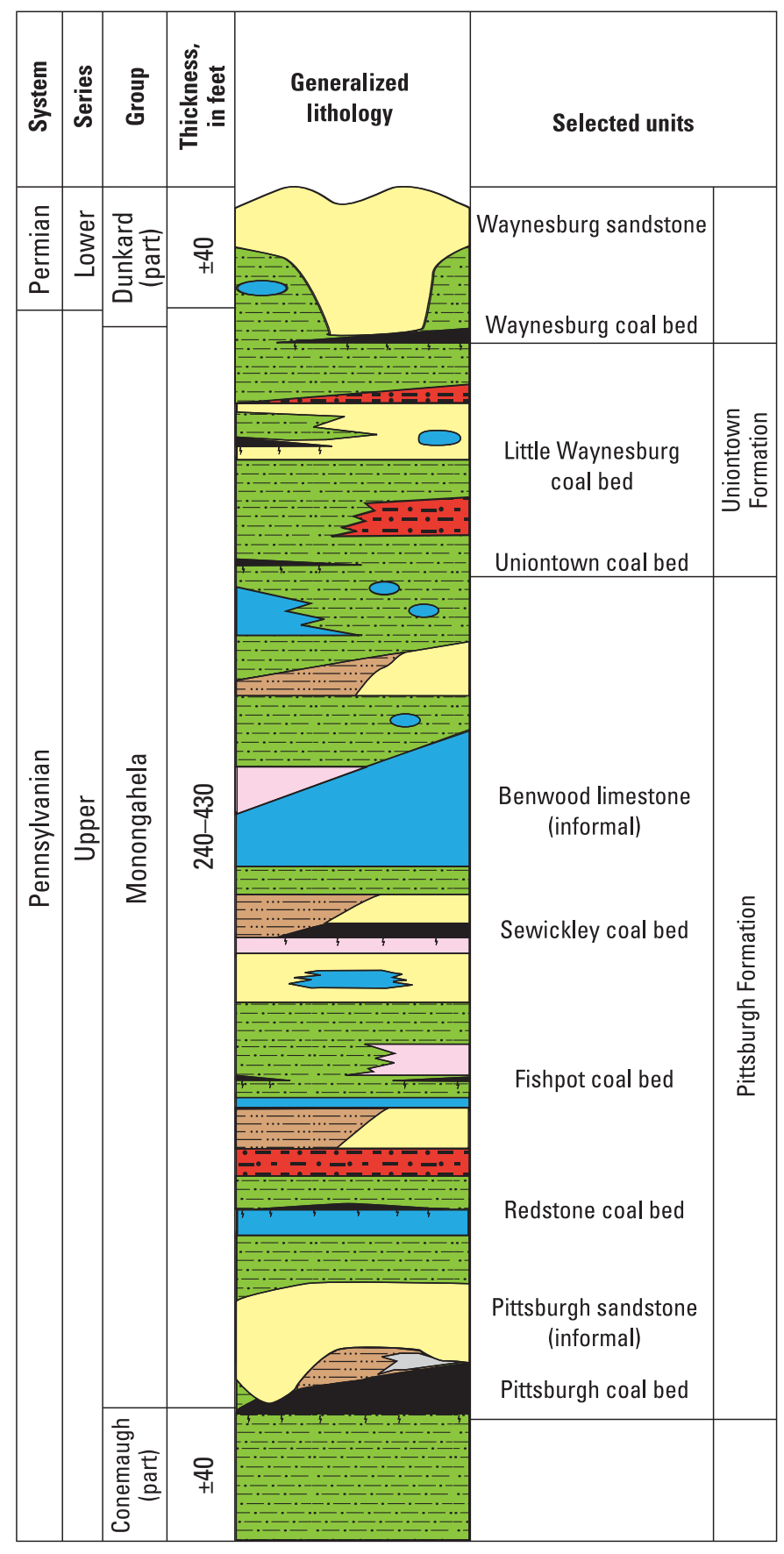

EXPLANATION

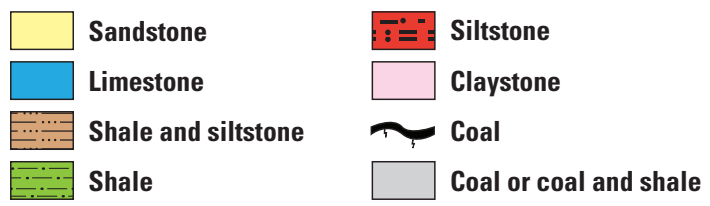

Figure 8. Generalized stratigraphic column of the Upper Pennsylvanian Monongahela Group, showing major coal beds and informal stratigraphic units present in Pennsylvania (from Tewalt, Ruppert, Bragg, Carlton, and others, 2001, fig. 3).
In 2003, CBM exploration in the northern Appalachian basin coal region was generally in the synclinal areas, where greater thicknesses of coal-bearing strata are preserved. Aside from wells drilled into mined Pittsburgh gob in Greene County, Pa., much of the recent drilling in Pennsylvania has occurred along the Uniontown (Latrobe) syncline, in Fayette, Westmoreland, and Indiana Counties (fig. 12; table 2, pool numbers 18-25) (Markowski, 2001).

In contrast, historical production of CBM in Wetzel County, W. Va. (which is adjacent to Pennsylvania), was chiefly from the Pittsburgh and Sewickley coal beds in the Big Run and Pine Grove fields (table 2) and was primarily from the anticlines rather than from synclines (Patchen and others, 1991). CBM was discovered in the Big Run field in 1932 and in the Pine Grove field in 1955. Patchen and others (1991) recognized the structural control on CBM production and on the occurrence of water within the Pittsburgh coal bed in these Wetzel County fields. Although gas occurs as a continuous accumulation in both anticlinal and synclinal areas, the Pittsburgh coal bed is generally wet, rather than dry, below a depth of about $260 \mathrm{ft}$ above sea level in the Big Run and Pine Grove fields. The wells that encountered free gas in dry coal beds along the anticlinal axes were preferentially completed by the early operators, whereas wet and nonproducing coal beds were generally not tested for gas. In the anticlinal traps in this area, free gas occurs in intermaceral porosity, open fractures, and cleats within the coal-bed reservoir; because of the lack of interstitial water, however, the amount of gas may have been diminished by leakage. In the synclinal occurrences, the water serves as a seal so that the amount of the methane per ton within the coal bed may be greater than in the anticlines. However, because of the water, it is likely that it would take a greater time to desorb an equivalent amount of gas from wells drilled in synclines than from wells in anticlinal areas (Patchen and others, 1991).

\section{Coalbed-Methane Fields and Pools}

The major CBM fields and pools in Pennsylvania and northern West Virginia are described in table 2, and fields are shown in figure 12; additional location data are given by Trippi and others (this volume, chap. I.1). All of the fields are in the East Dunkard AU. As of 2005, about 214 commercial CBM wells had been drilled in Pennsylvania (table 1), although many were not producing. Of these, 132 wells drilled in unmined seams were completed using hydraulic fracturing and stimulation. The other wells tested and produced gas (coal-mine methane) from gob in active and abandoned mines (A.K. Markowski, Pennsylvania Bureau of Topographic and Geologic Survey, written commun., 2003).

[Text continues on page 22.] 


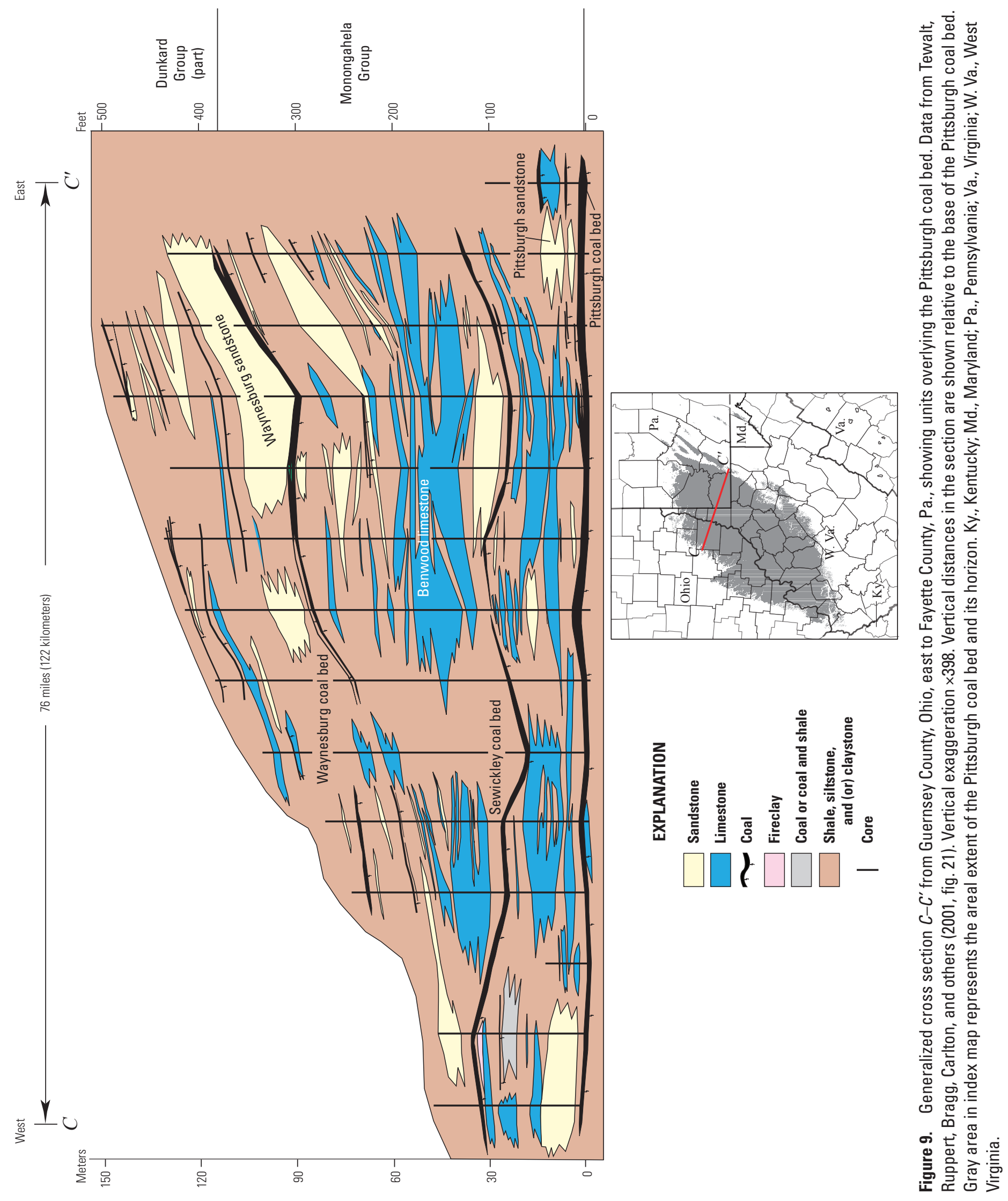




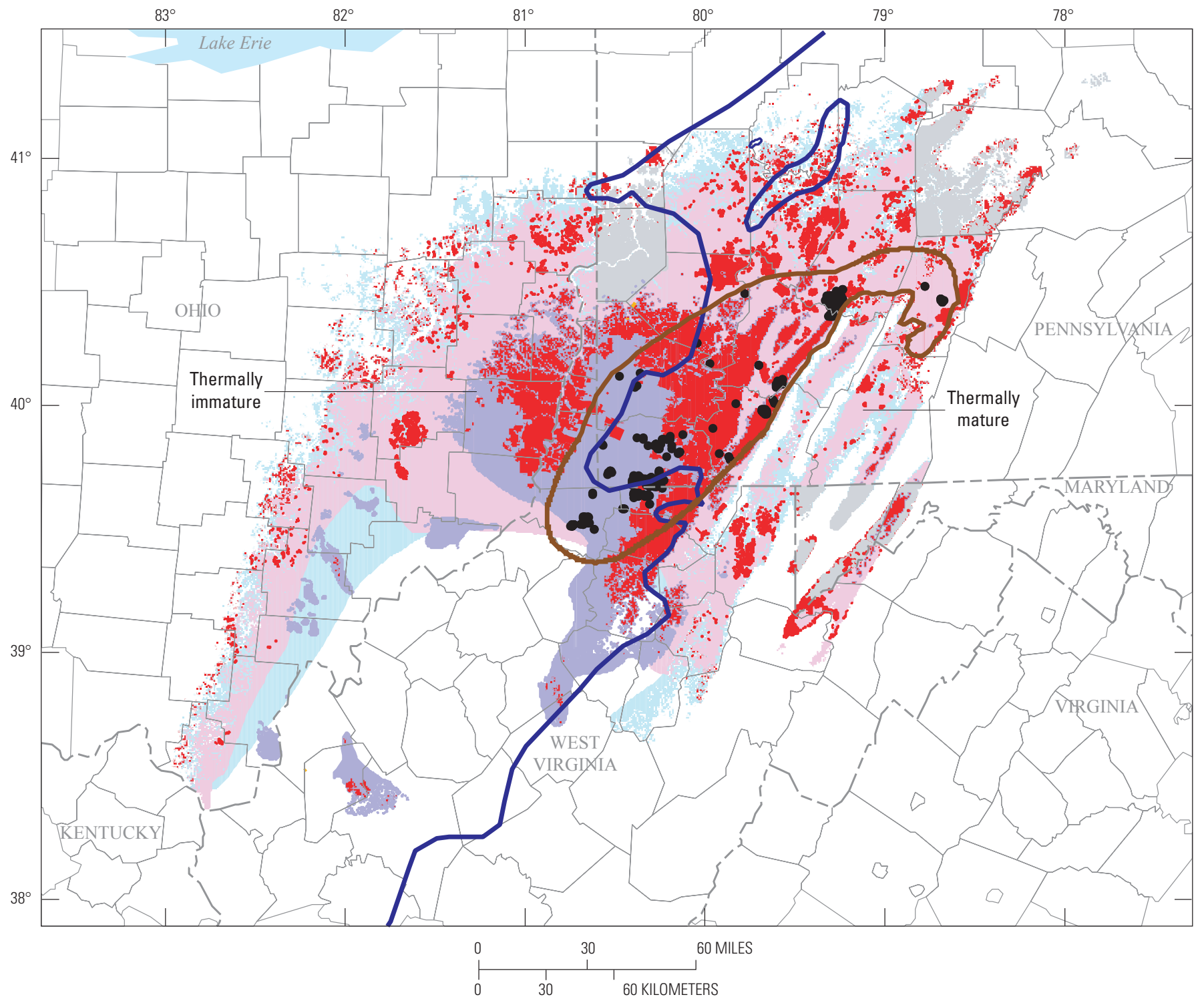

EXPLANATION

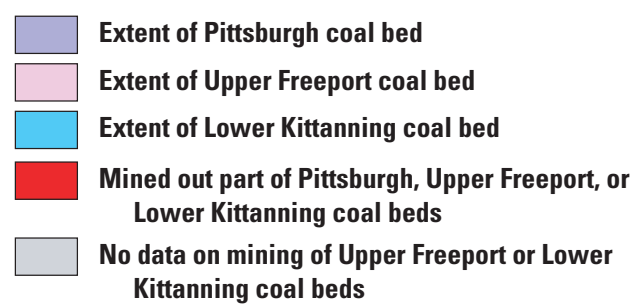

Figure 10. Map showing location of coalbed-methane (CBM) wells with respect to major coal beds in the northern Appalachian basin coal region and the vitrinite reflectance $\left(R_{0}\right)$ isoline of 0.8 percent. The generalized isoline is based on unpublished data provided by Leslie Ruppert (U.S. Geological Survey) in 2002. Thermally immature areas west of the main isoline have vitrinite reflectance values less than $0.8 \% \mathrm{R}_{\mathrm{o}}$ and have less likelihood of thermogenic CBM than thermally mature areas east of the isoline,

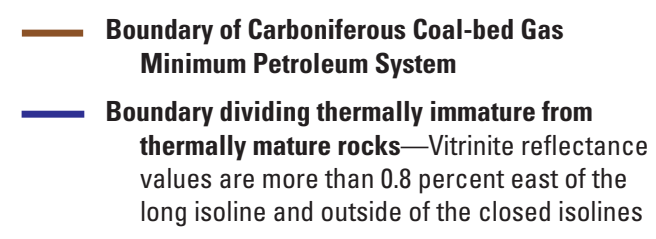

- Coalbed-methane well

which are in the East Dunkard Assessment Unit (fig. 2). Data on the Pittsburgh coal bed are from Tewalt, Ruppert, Bragg, Carlton, and others (2001, figs. 14 and 22); data on the Upper Freeport coal bed are from Ruppert and others (2001, figs. 3, 20, and 24); and data on the Lower Kittanning coal bed are from Milici, Freeman, and others (2001, fig. 5). Locations of CBM wells are from Markowski (2000) and Avary (2004). 


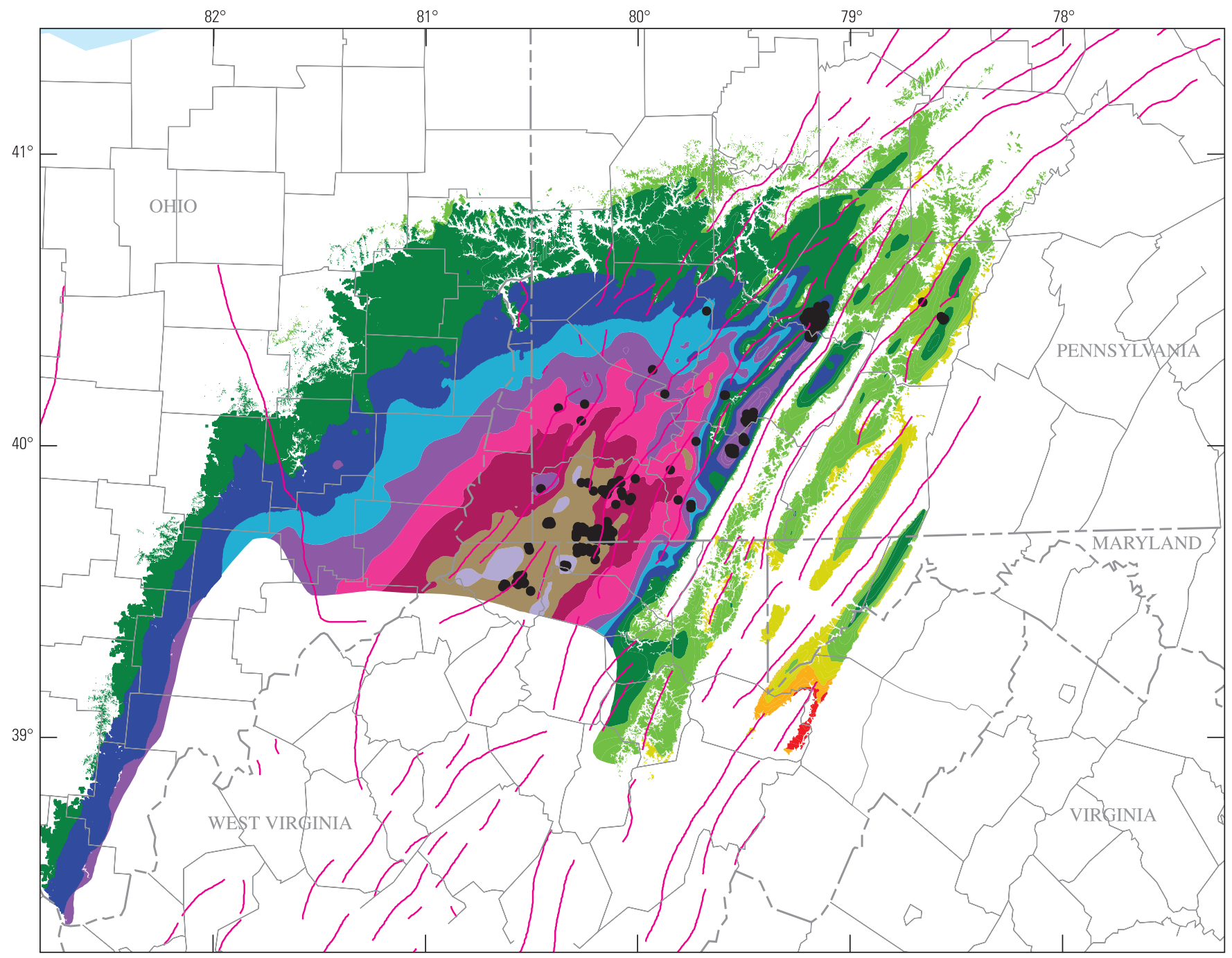

EXPLANATION

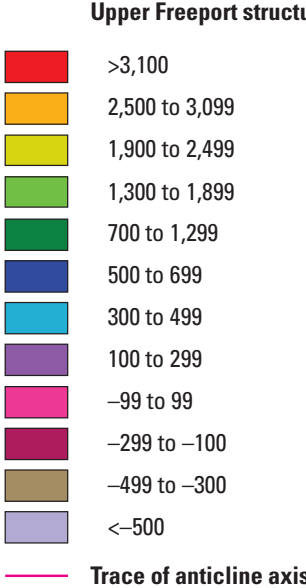

- Coalbed-methane well

Figure 11. Structure-contour map of the top of the Upper Freeport coal bed in the northern Appalachian basin coal region; contours are relative to mean sea level (modified from Ruppert and others, 2001, fig. 21). Coalbed-methane wells and traces of anticline axes are from figure 2. 


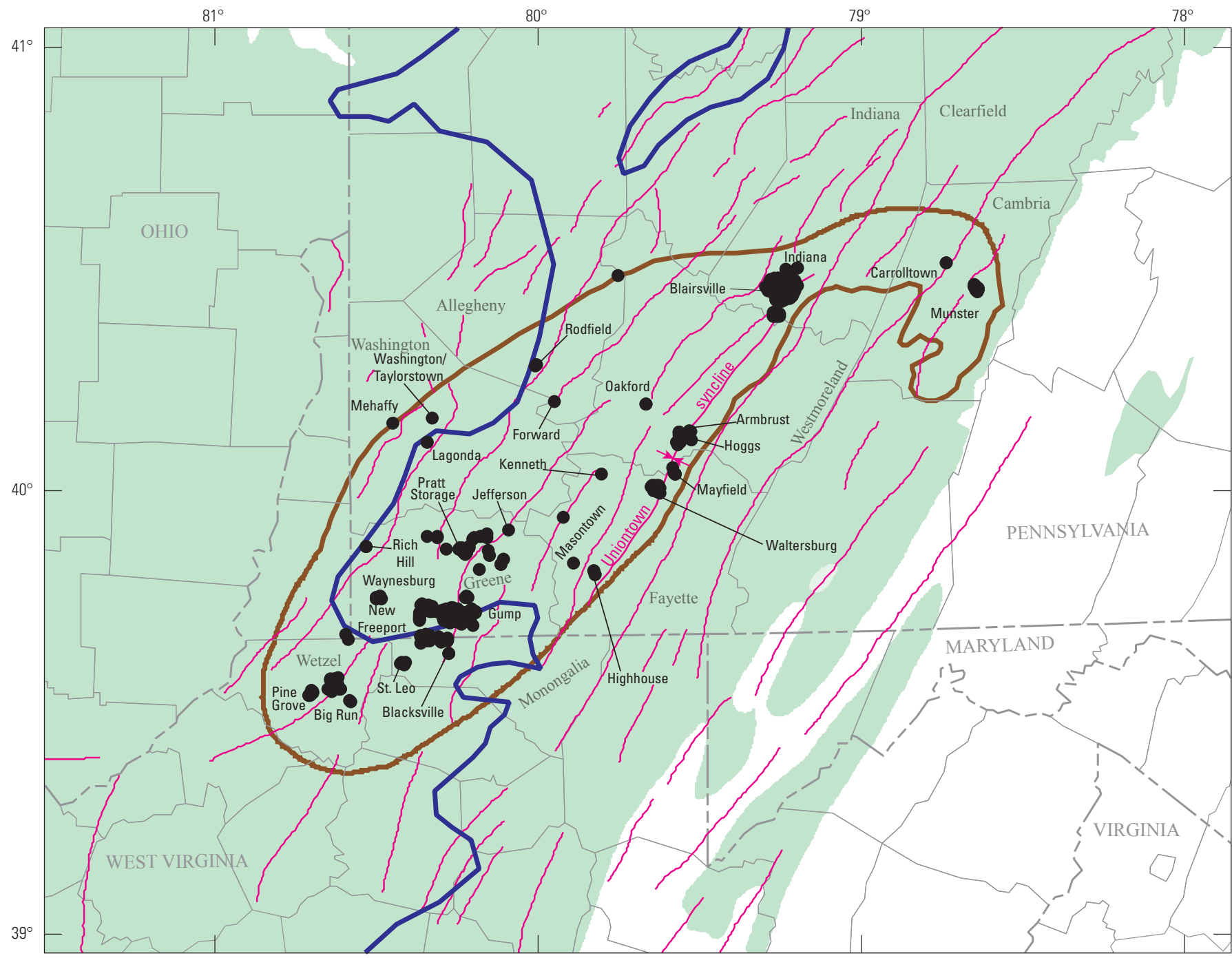

\section{EXPLANATION}

Part of the northern Appalachian basin coal region

Boundary of Carboniferous Coal-bed Gas

Minimum Petroleum System

_ Generalized vitrinite reflectance isoline dividing thermally immature from thermally mature rocks-Vitrinite

reflectance values are more than 0.8 percent east of the long isoline and outside of the closed isoline

\section{Trace of anticline axis}

$\downarrow$ Trace of Uniontown syncline axis

- Coalbed-methane well

Figure 12. Map showing major coalbed-methane (CBM) fields (names in small black type) and CBM wells of the northern Appalachian basin coal region with respect to the vitrinite reflectance $\left(R_{0}\right)$ isoline of 0.8 percent. The generalized isoline is based on unpublished data provided by Leslie Ruppert (U.S. Geological Survey) in 2002; see also figure 10 of this report. CBM wells and traces of anticline axes are from figure 2. Selected counties are labeled. Data on CBM fields are in table 2. 


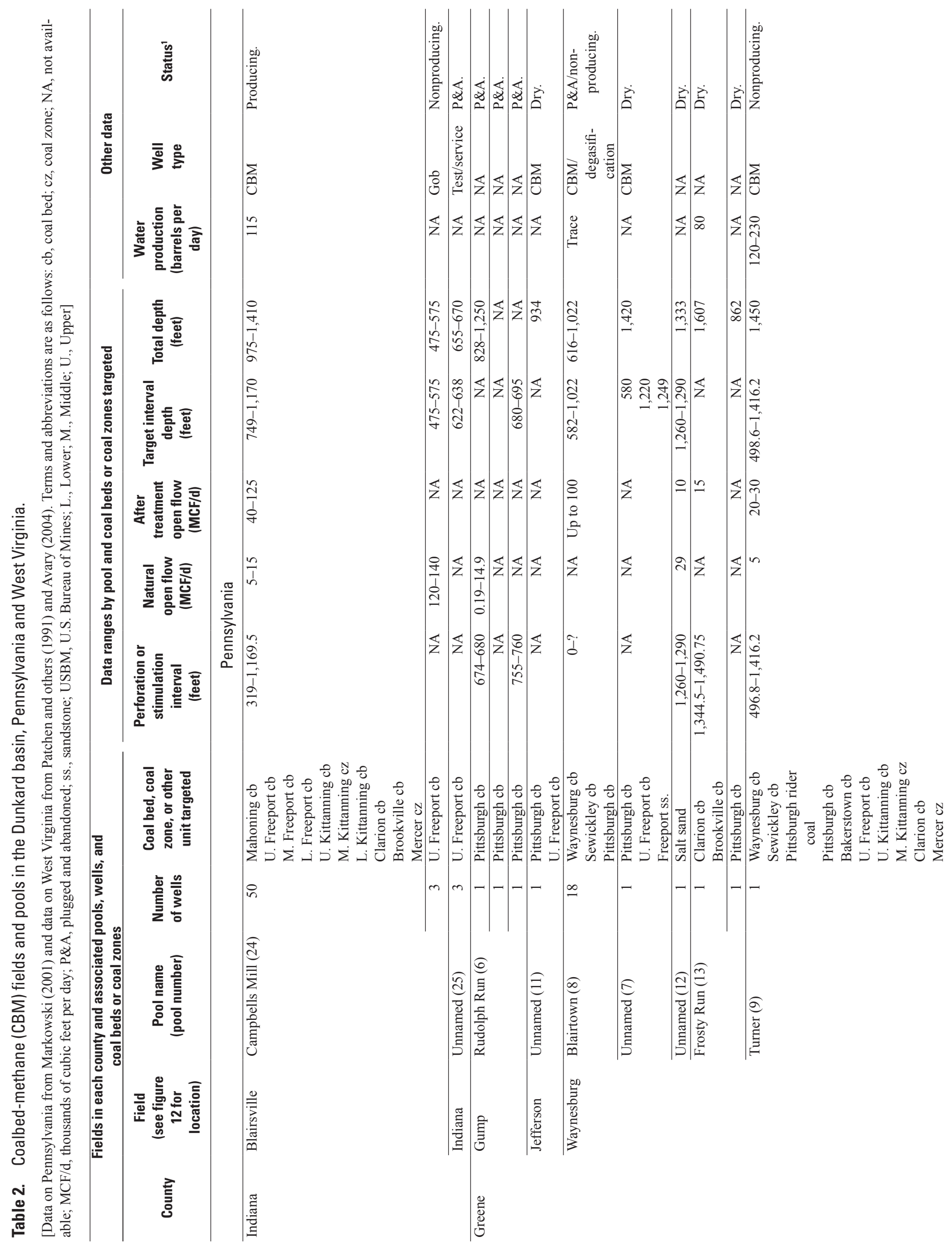




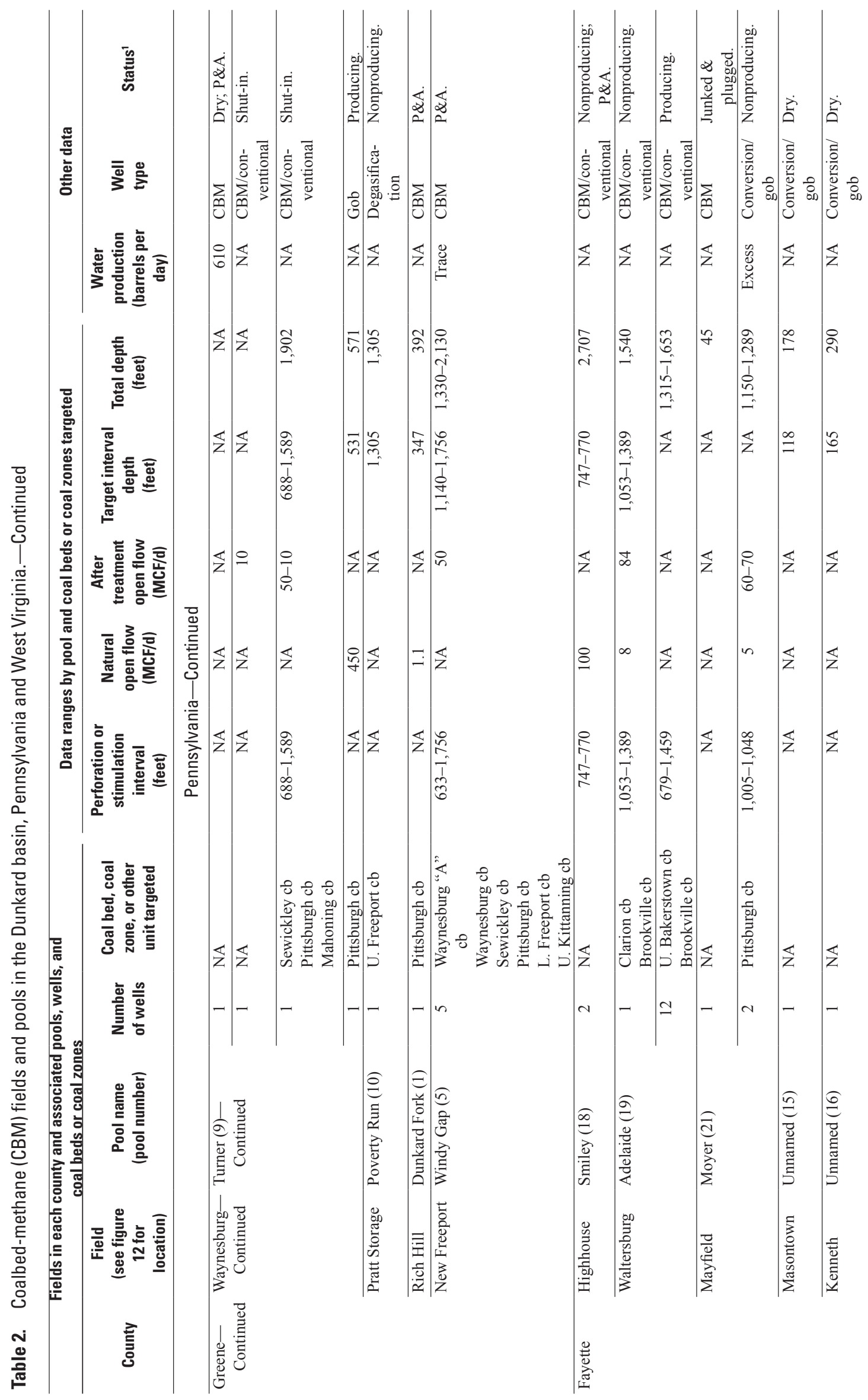




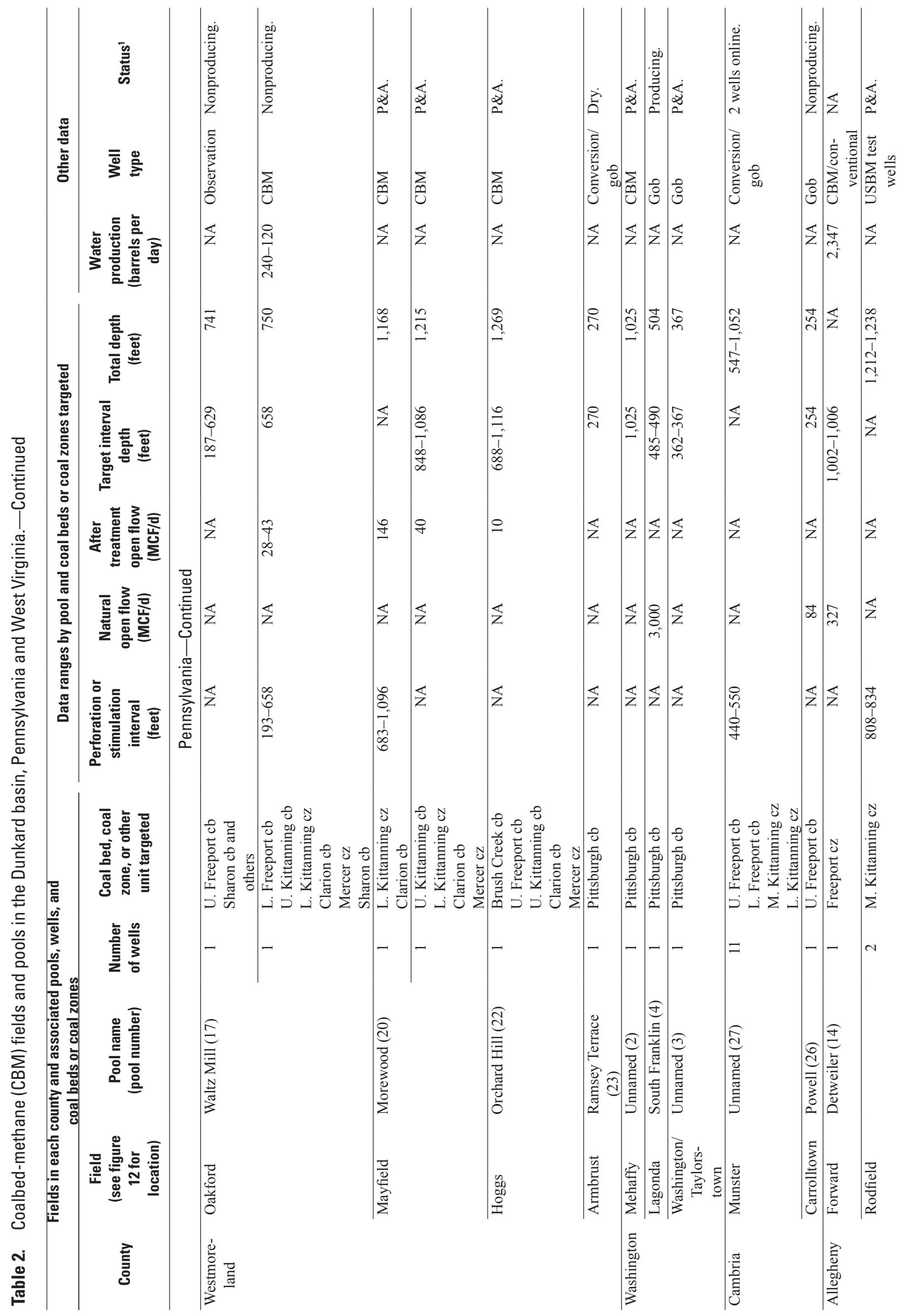




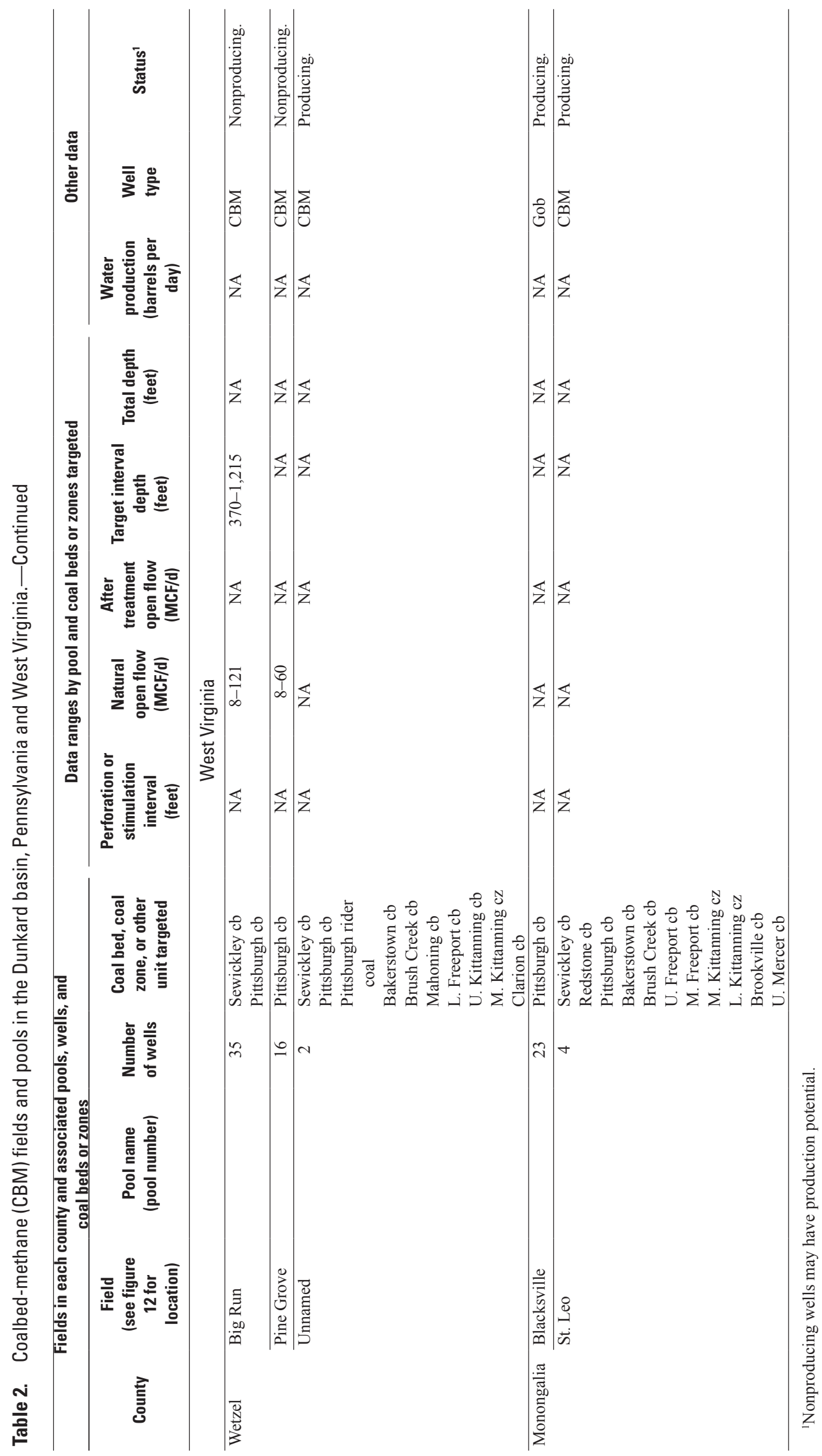


Production in Pennsylvania in 2003 was from four fields: Blairsville field in Indiana County, Munster field in Cambria County, Waltersburg field in Fayette County, and Lagonda field in Washington County (fig. 12). In addition, gob gas was being produced from several wells in Greene County. By far, the most productive area in Pennsylvania was in Indiana County, from the Campbells Mill pool in the Blairsville field, where CBM was produced primarily from coal beds in the lower part of the Conemaugh Group, the Allegheny Group, and the upper part of the Pottsville Group (Markowski, 2001; A.K. Markowski, oral commun., 2001). In 2002, Indiana County produced about 865 MMCF of CBM (A.K. Markowski, written commun., 2003).

In 2003, two wells were producing CBM from multiple coal horizons in Wetzel County, W. Va. (table 2). In Monongalia County, W. Va., 23 wells were producing CBM from the gob of the Pittsburgh coal bed in the Blacksville mine, and 4 wells were producing from multiple coal beds in the St. Leo field (Avary, 2004). In Ohio by 2004, CBM of probable microbial origin had been produced for local uses from several gob wells in Harrison County in the West Dunkard AU (Wolfe, 1997; Slucher and McDonald, 2004).

\section{Coal as a Source Rock for Coalbed Methane}

\section{Gas-in-Place Data}

In autogenic (self-sourced) accumulations, such as coalbed methane, the source rocks and the reservoirs are the same stratigraphic unit. Accordingly, gas-in-place (desorption) data may provide a direct indication of potential production. Almost all of the gas-in-place data used in this report were compiled and published by the former U.S. Bureau of Mines (Diamond and others, 1986); for this report, the data were converted from cubic centimeters per gram to cubic feet per short ton ( $\mathrm{CF} /$ ton). The gas values reported by Diamond and others (1986) were measured at ambient field and laboratory conditions and were not corrected to standard temperature and pressure (STP).

For the northern Appalachian basin bituminous coal fields, gas-in-place data range from 10 to $442 \mathrm{CF} /$ ton; the largest values are in Indiana, Westmoreland, and Greene Counties, Pa., and Barbour County, W. Va. (fig. 13). Because of the great differences in the numbers of gas desorption samples from different counties, the largest available value was plotted for each county in figure 13, rather than an average value for each county. In counties for which there are few samples, however, it is very likely that larger desorption values would be obtained from additional tests. Where the number of samples is large (say 50 or more, as in two counties), the largest value may approximate the upper end of the sample size distribution. Available data indicate that the average gas contents for three significant coal units are as follows: Pittsburgh coal bed, about $140 \mathrm{CF} /$ ton; Freeport coal zone, about $192 \mathrm{CF} /$ ton; and Kittanning coal zone, about $252 \mathrm{CF} /$ ton (Bruner and others, 1995, 1998).

\section{Thermal Maturity}

The coal beds are considered thermally mature with respect to methane generation at vitrinite reflectance values that exceed approximately $0.8 \% \mathrm{R}_{\mathrm{o}}$. Almost all of the vitrinite reflectance data used in this report were unpublished data supplied by Leslie Ruppert (USGS, 2002); updated reflectance data and thermal maturation maps are given by Ruppert and others (this volume, chap. F.2). Much of the coal-bed gas to the east of the $0.8-\% \mathrm{R}_{\mathrm{o}}$ isoline in the eastern part of the East Dunkard (Folded) AU is probably thermogenic (fig. 10). In southwestern Pennsylvania, adjacent to the $0.8-\% \mathrm{R}_{\mathrm{o}}$ isoline, microbial gas in Pennsylvanian coal beds has been reported mixed with thermogenic gases (Laughrey and Baldassare, 1998). However, it is likely that much of the CBM to the west of the $0.8-\% \mathrm{R}_{\mathrm{o}}$ isoline is of microbial origin.

Although there is considerable potential for the generation and accumulation of microbial CBM in the southern part of the East Dunkard (Folded) AU and generally throughout the area of the West Dunkard (Unfolded) AU, the area that is thermally mature $\left(>0.8 \% \mathrm{R}_{0}\right)$ has a greater potential for CBM development than the areas that are immature. The thermally mature area includes almost all of the area developed by late 2003 (figs. 10, 12, and 14).

\section{Generation and Migration}

Microbial methane almost certainly has been generated since the formation of the first peat deposits in the Pennsylvanian to the present day, wherever surface waters interact with shallow coal beds (Laughrey and Baldassare, 1998). Thermal maturation commenced toward the end of the Paleozoic to the east, in the deeper part of the Appalachian Plateaus, where it may have been enhanced by Alleghanian folding and faulting. Thermal maturity probably was reached in the eastern half of the Dunkard basin during the latest Paleozoic and earliest Mesozoic (fig. 15), prior to erosion associated with regional uplift and crustal extension during the early Mesozoic.

In autogenic CBM accumulations, only local desorption of gases from coal macerals into micropores and natural fractures is needed to charge the reservoir. However, long-distance migration of CBM along coal beds is unlikely, especially if the coal beds are wet, because formation waters would inhibit desorption of methane into a fracture network. In contrast, relatively porous sandstone beds adjacent to coal source rocks may provide a network of fractures and pore spaces sufficient to support long-distance migration of desorbed gases. 


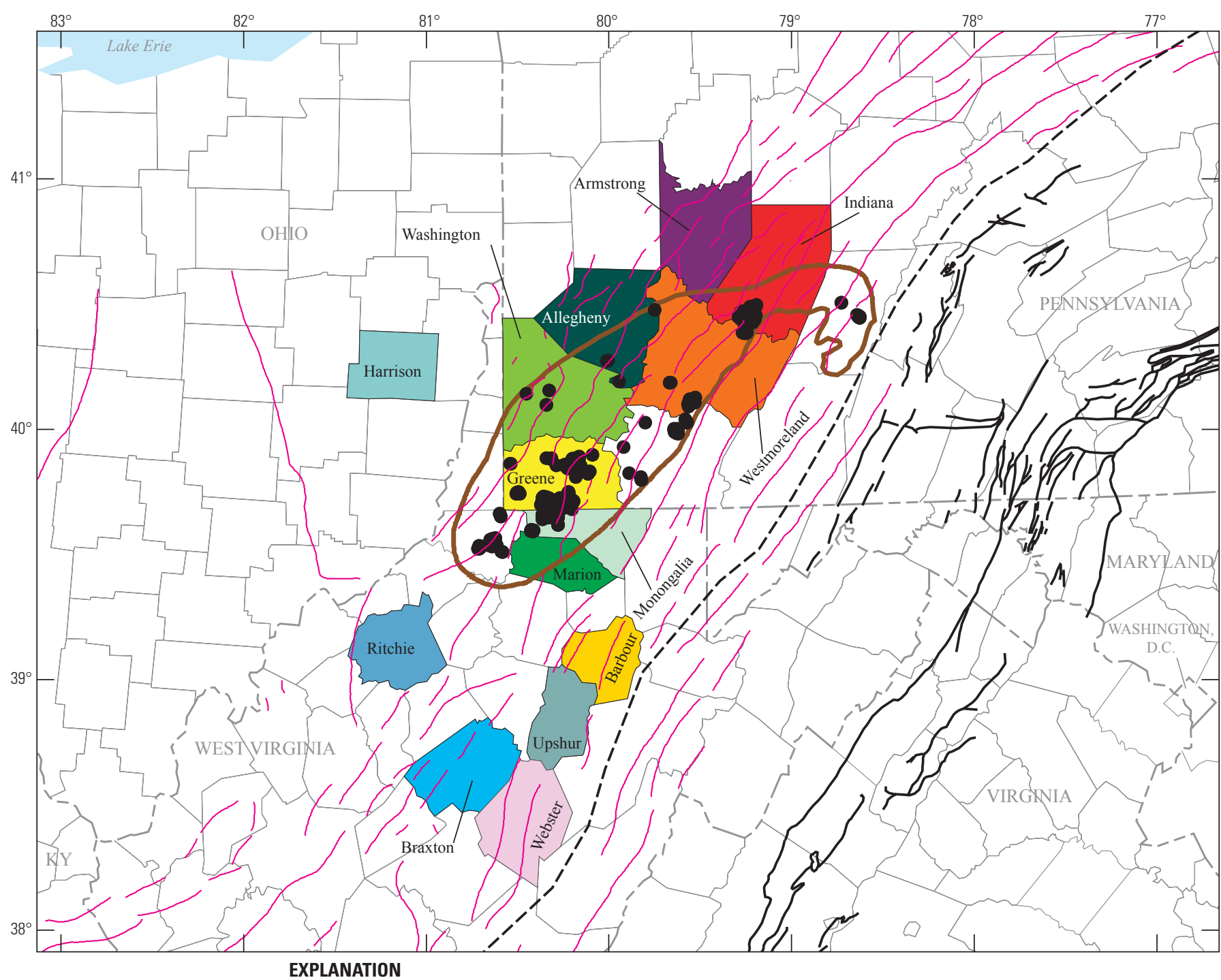

Greatest measured gas-in-place values per countyIn cubic feet per short ton (CF/ton)

$442, n=9$

$358, n=27$

294, $n=22$

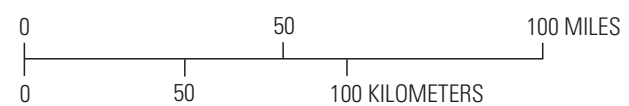

266, $n=188$

224, $n=11$

$189, n=111$

$166, n=18$

$160, n=17$

$118, n=12$

$90, n=20$

$83, n=11$

$80, n=3$

29, $n=6$

$22, n=4$

Boundary of Carboniferous Coal-bed Gas Minimum Petroleum System

- - - Allegheny structural front

Appalachian thrust fault

- Trace of anticline axis

- Coalbed-methane well

Figure 13. Map showing a direct measurement of gas-in-place content in coal beds for selected counties in the northern Appalachian basin coal region. Data on gas content from Diamond and others (1986). $n$, number of samples. Largest measured gas-in-place content in cubic feet per short ton (CF/ton) is plotted on map for each county. Coalbed-methane wells, thrust faults, and traces of anticline axes from figure 2 . 


\section{Coal as a Reservoir for Coalbed Methane}

\section{Porosity and Permeability}

Coal beds are structurally weak when compared with the enclosing strata. As a result, coal beds are highly susceptible to deformation when they are folded or faulted. In order for gas production to occur, desorbed methane in small pore spaces (micropores, macropores) must first migrate into fracture systems, either natural or human induced, on the way to a wellbore. Effective methane production, thus, depends upon the development of an extensive fracture system within coalbed reservoirs. Natural fractures include face and butt cleats, as well as fractures formed by structural deformation.

In general, abundant, closely spaced orthogonal cleat systems, which form relatively early in the coalification process, are widespread in the Appalachian basin bituminous coal fields (Bruner and others, 1995, 1998). In many places, however, coal beds contain additional natural fractures that are related to Appalachian structural deformation and have been superimposed upon previously existing cleats. Although tectonically induced fractures may destroy the fabric of previously formed cleats in some places, they commonly increase the fracture porosity of the deformed coal beds. Pashin and Hinkle (1997) maintained that where the dip of folded coal measures exceeds $10^{\circ}$, cleat is commonly destroyed and is replaced by closely spaced inclined fractures and normal faults within the coal beds. Accordingly, large-scale folding in Pennsylvania and West Virginia in the East Dunkard AU very likely has increased the fracture porosity of target coal beds in those areas as the coal beds were preferentially deformed by interstratal slip during deformation. Furthermore, Harris and Milici (1977), Milici and Gathright (1985), and Milici and others $(1982,1986)$ have described the occurrence of beddingparallel faults and associated structures within coal beds in Tennessee and Virginia that may significantly increase fracture porosity, both within the coal beds and in the enclosing strata. Similar structures may exist in the northern Appalachian basin coal region.

\section{Coal-Bed Distribution}

Figure 10 illustrates the known distribution of the three major coal-producing beds in the northern Appalachian basin coal region: the Lower Kittanning, Upper Freeport, and Pittsburgh coal beds, together with the areas of known mining. Figure 10 was compiled from maps in chapters of USGS Professional Paper 1625-C (Northern and Central Appalachian Basin Coal Regions Assessment Team, 2001); see the caption for details. The maps show that these coal beds do not extend to the southwest, from Pennsylvania into central West Virginia. Although the map of the Pittsburgh coal bed reflects the distribution of this bed in the deep part of the basin with a reasonable degree of certainty, the maps of the Upper Freeport and Lower Kittanning coal beds do not. The correlations of
Allegheny Group coals with their equivalents in southern West Virginia, easternmost Ohio, and eastern Kentucky were not well enough understood to justify their extension into those areas.

\section{Cumulative Coal Thickness}

A cumulative coal thickness of 15 to $20 \mathrm{ft}$ or more, distributed over several coal beds, is considered favorable for CBM development. Bruner and others (1995, 1998, fig. 41, their net coal isolith map) have shown that much of the area in southwestern Pennsylvania and northern West Virginia is underlain by a cumulative coal thickness in their operational Allegheny Formation that exceeds $15 \mathrm{ft}$. Their operational Allegheny Formation is defined above in the description of the "Conemaugh Group."

\section{Seals}

\section{Depth of Burial}

Much of the CBM production in the northern Appalachian basin coal region is in the deeper part of the Dunkard basin. A depth of burial to the target coal beds of $500 \mathrm{ft}$ or more is considered necessary to seal the gas within potential reservoirs (see Markowski, 2001, for a summary). Although the possibility of obtaining large amounts of microbial gas from shallow, wet reservoirs cannot be disregarded, those areas may require a cumulative coal thickness of 15 to $20 \mathrm{ft}$, or more, in order to generate an economic volume of gas.

\section{Water Production}

Connate water contained within the natural fractures of the coal beds is an effective seal. In many CBM reservoirs, this water must be removed by pumping to reduce reservoir pressure and initiate gas production. For example, in the Blairsville field in Pennsylvania, CBM wells completed in wet coal beds may produce as much as 30,000 to 50,000 gallons of water during their first few years (Markowski, 2000). The water is sent to a treatment facility and discharged into nearby surface drainage (Markowski, 1998).

\section{Cumulative Production and Estimated Ultimate Recovery Data}

Cumulative production data provide another indicator of potential in the greatly under-explored region of the Dunkard basin. The counties that have produced $1 \mathrm{BCF}$ of gas, or more, include Wetzel and Monongalia Counties in West Virginia and Washington, Greene, and Indiana Counties in Pennsylvania (table 1, fig. 14). These counties are in or near the area that is thermally mature $\left(>0.8 \% \mathrm{R}_{\mathrm{o}}\right)$ and are in the deeper part of 


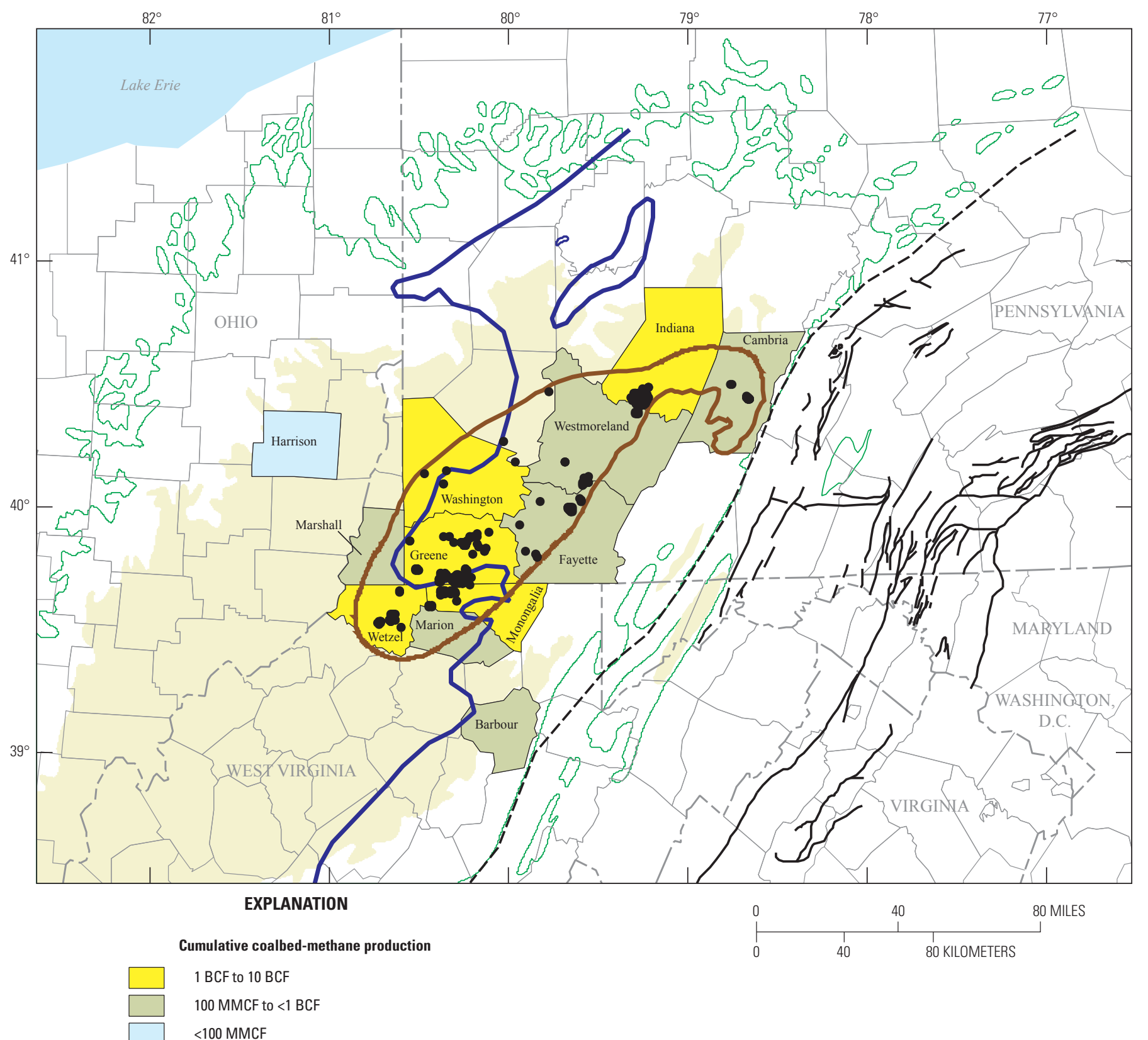

st Dunkard and West Dunkard

Assessment Units-Outer boundary is generally defined by the cropline of the base of the Conemaugh Group

- Boundary of Carboniferous Coal-bed Gas Total Petroleum System

Boundary of Carboniferous Coal-bed Gas Minimum Petroleum System

- Allegheny structural front

Figure 14. Map showing cumulative production of coalbed methane (CBM) for selected counties in the northern Appalachian basin coal region by 2005. CBM production data from sources identified in table 1.

Generalized vitrinite reflectance isoline dividing thermally immature from thermally mature rocks - Vitrinite reflectance values are more than 0.8 percent east of the long isoline and outside of the closed isoline Vitrinite reflectance $\left(R_{0}\right)$ isoline of 0.8 percent generalized from unpublished data provided by Leslie Ruppert (U.S. Geological Survey) in 2002; see also figure 10 of this

- Coalbed-methane well report. CBM wells and thrust faults from figure 2. 


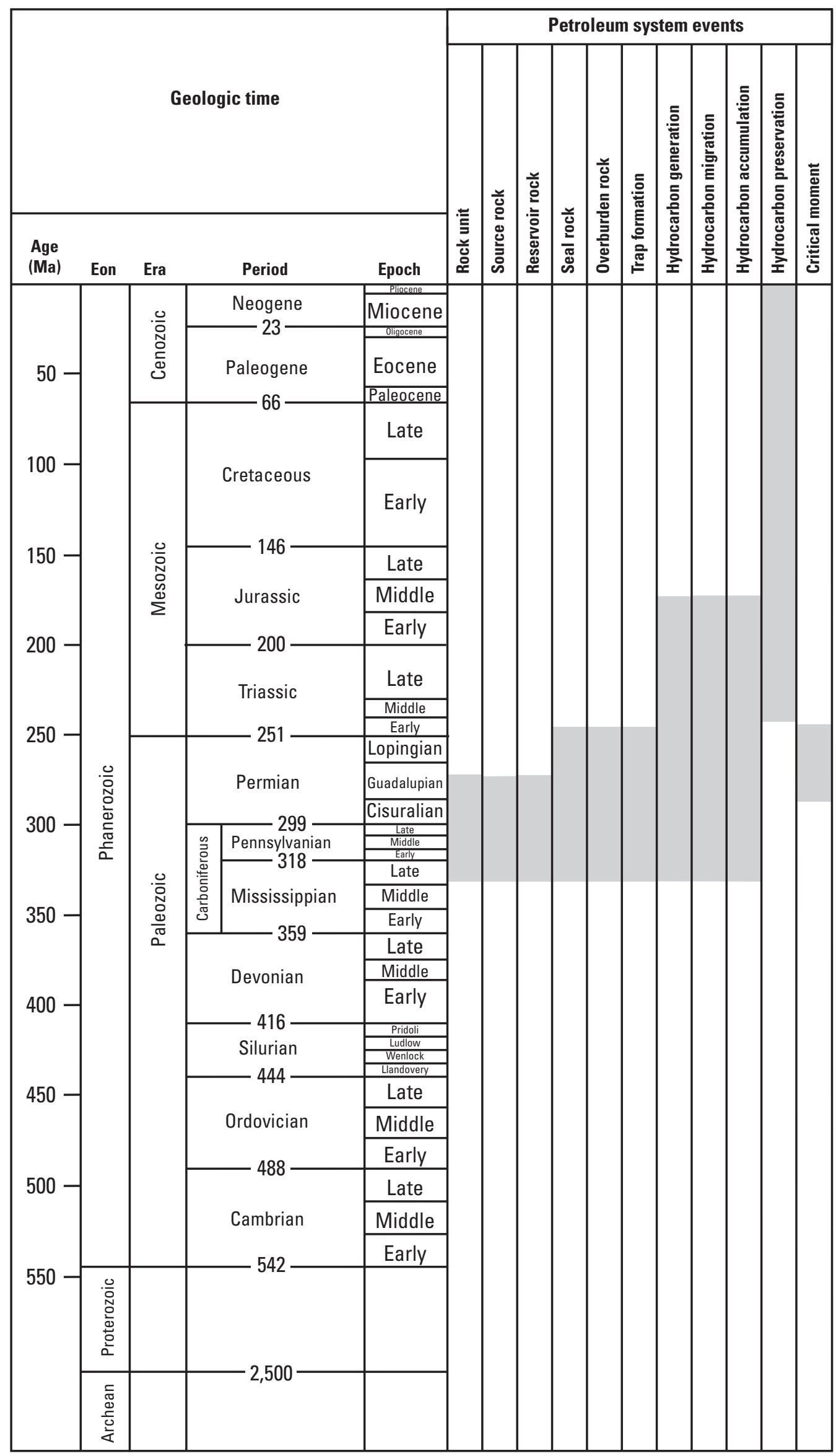

Figure 15. Events chart for thermogenic coalbed methane in the Carboniferous Coal-bed Gas Total Petroleum System in the Appalachian Basin Province. Estimated ages of geologic period boundaries in millions of years ago (Ma) from U.S. Geological Survey Geologic Names Committee (2007). 
the Dunkard basin. Although much of the historical CBM production in Greene and Washington Counties, Pa., and in Monongalia County, W. Va., was from gob associated with the mining of the Pittsburgh coal bed, CBM wells were successfully completed in unmined coal beds in the now-abandoned Pine Grove and Big Run gas fields, in a new unnamed field in Wetzel County, and in the St. Leo field in Monongalia County, W. Va. The Blairsville field, which produces almost all of the gas in Indiana County, Pa., had produced approximately 6.6 BCF as of 2005 (table 1).

Patchen and others (1991, fig. 24), in their study of the Big Run field, plotted the average annual CBM production per well of seven wells for their 35-year history. The average estimated ultimate recovery (EUR) for these wells is about 120 MMCF of methane. Rice and Finn (1996) used an EUR of $121 \mathrm{MMCF}$ for the Northern Appalachian Basin Anticline Play and 216 MMCF for the Northern Appalachian Basin Syncline Play. Both of these plays were assessed as analog plays. The 2002 USGS assessment (Milici and others, 2003) used a mean value of $160 \mathrm{MMCF}$ for the EUR for the Carboniferous Coal-bed Gas Minimum Petroleum System area of the East Dunkard AU.

\section{Assessment Results}

The principal area of the Dunkard basin that was assessed quantitatively by the USGS in the 2002 assessment is that designated as the Carboniferous Coal-bed Gas Minimum Petroleum System in western Pennsylvania and adjacent West Virginia (figs. 2, 10, 12, 13, and 14). That minimum petroleum system is in the northeastern part of the East Dunkard (Folded) AU. That area was considered the most likely to be developed within the 30-year timeframe of the USGS assessment.

Results of the USGS assessment are in table 3. The USGS estimated a mean of about 4.8 TCF of technically recoverable methane for the East Dunkard (Folded) AU (Milici and others, 2003). This value is significantly less than the CBM assessment of Rice and Finn (1996) for the northern Appalachian basin coal region; they reported a mean undiscovered resource of about 11.5 TCF for a much larger area in the coal region. Furthermore, Rice and Finn (1996) used an analog methodology for the Appalachian CBM assessment, primarily because they had little or no exploration and production data on which to base their assessment and because their assessment was not constrained by a 30 -year timeframe.

The West Dunkard (Unfolded) AU and the southwestern part of the East Dunkard (Folded) AU were not assessed (table 3). The West Dunkard AU area is immature with respect to thermogenic methane generation and contains little structure that would enhance coal-bed porosity. The gas that was produced in this area from an underground mine complex in Harrison County, Ohio (Wolfe, 1997; Slucher and McDonald, 2004), may have been mostly of microbial origin. Any significant discovery in this relatively untested area could affect future CBM assessments greatly.

\section{Pocahontas Basin and Central Appalachian Shelf Assessment Units}

\section{Introduction}

For CBM assessment purposes, the central Appalachian basin coal region was divided into two assessment units: the Pocahontas Basin Assessment Unit and the Central Appalachian Shelf Assessment Unit (fig. 16). In general, the CBM resources of the Pocahontas basin have been well developed during the past several decades, whereas the Central Appalachian Shelf has been little explored for CBM.

The Pocahontas basin lies along the eastern margin of the Appalachian Plateaus, where it extends along regional structural strike for about $200 \mathrm{mi}$, from eastern Kentucky, through

Table 3. Estimates of total undiscovered coalbed-methane resources of the Carboniferous Coal-bed Gas Total Petroleum System.

[Estimates from Milici and others (2003). Results shown are fully risked estimates made in 2002 for the U.S. Geological Survey National Oil and Gas Assessment, which had a 30-year timeframe. F95 denotes a 95-percent chance of at least the amount tabulated. Other fractiles are defined similarly. BCF, billions of cubic feet]

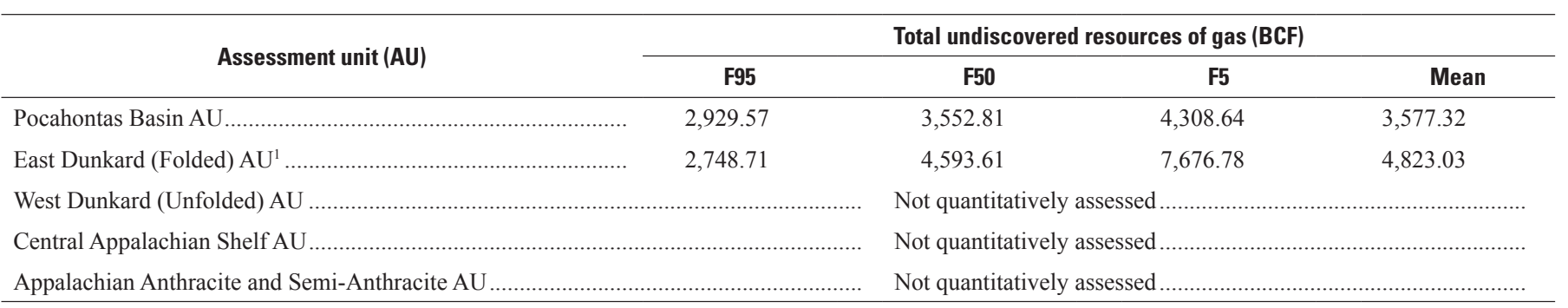

${ }^{1}$ All the undiscovered coalbed methane estimated to exist in the East Dunkard (Folded) AU is in the Carboniferous Coal-bed Gas Minimum Petroleum System (figs. 2, 10, 12, 13, and 14). The minimum petroleum system is in the northeastern part of the East Dunkard (Folded) AU. The southwestern part of the East Dunkard (Folded) AU was not assessed. 
southwestern Virginia, to southern West Virginia. Because of its location along the eastern margin of the Appalachian foreland basin, the Pocahontas basin contains the greatest thickness of Pennsylvanian strata and the largest number of bituminous coal beds in the central part of the Appalachian basin. Coal has been produced from the Pocahontas basin for more than 150 years, and there are about 30 major named coal beds in the basin that are commercially mined for coal. The boundary between the Pocahontas Basin AU and the Central Appalachian Shelf AU lies generally along the western limit of the Pocahontas Formation in the subsurface, which occurs from near the Virginia-Kentucky State line to a few miles into eastern Kentucky from Virginia (Englund and Thomas, 1990).

The Central Appalachian Shelf, which occupies an area about $270 \mathrm{mi}$ long and 50 to $75 \mathrm{mi}$ across, extends from the Wartburg basin in Tennessee (Milici and others, 1979) across eastern Kentucky, to the broad structural arch in West Virginia that lies between the Dunkard basin on the north and the Pocahontas basin on the south (figs. 1 and 16). In eastern Kentucky and Tennessee, the predominant structure of this region is the regional dip of the Appalachian Plateaus, from the Cincinnati arch on the west, eastward into the Appalachian basin. In general, the arch has been a positive structural element since its inception in the Ordovician (Wilson, 1949), so that Ordovician and younger strata thin westward away from the Appalachian basin and commonly wedge out over the arch. Accordingly, the preserved thickness of the coal-bearing Pennsylvanian rocks decreases from several thousand feet to a few hundred feet generally from southeast to northwest across the basin. There are about 30 major coal beds or coal zones along the eastern side of the Central Appalachian Shelf AU, where it is near the deeper part of the basin. To the west, where the Pennsylvanian stratigraphic sequence laps onto the Cincinnati arch and is partly truncated by erosion, there are fewer coal beds and they are much less deeply buried (Rice, 1986; Englund and Thomas, 1990). Although this part of the Appalachian basin has been extensively explored for conventional oil and gas, at present there is no commercial production of CBM from the Central Appalachian Shelf AU.

\section{Stratigraphy}

The Pennsylvanian stratigraphic nomenclature of the Central Appalachian Shelf AU (in Tennessee, eastern Kentucky, and southern West Virginia) and the Pocahontas Basin AU (in Virginia and southern West Virginia) is shown in figure 17. It is anticipated that the greatest potential for CBM development in the shelf area may be in the lower part of the Breathitt Formation in eastern Kentucky and its equivalents in Tennessee, as well as in coal beds in the Lee Formation and its equivalents. Similarly, most of the CBM production in the Pocahontas basin in Virginia and West Virginia has been from coal beds in the Pocahontas and New River Formations and their lateral equivalents.

\section{Pocahontas Formation}

The Pocahontas Formation, which is the lowest Pennsylvanian stratigraphic unit in the central Appalachian basin, extends generally northeastward from the Virginia coal field into adjacent West Virginia; it extends northwestward from its cropline along the eastern margin of the Appalachian coal basin into the subsurface to where it is as much as $2,500 \mathrm{ft}$ deep. To the west, deep in the subsurface of Virginia and southern West Virginia, the Pocahontas Formation may be truncated by a regional unconformity that may cut downward through Pennsylvanian strata (Englund, 1979; Englund and Thomas, 1990). In some places, the Pocahontas is laterally equivalent to the Lee Formation; in other places, the Lee overlies it, and elsewhere it is overlain unconformably by the New River Formation. The Pocahontas Formation contains the largest resource of low-sulfur coking coal in the central part of the Appalachian basin, which is produced from the Pocahontas No. 3 coal bed (McColloch, 1995).

The Pocahontas Formation is a sandstone-dominated sequence that consists of as much as $980 \mathrm{ft}$ of sandstone, siltstone, shale, and low-sulfur coal along its outcrop in Virginia and West Virginia (Englund, 1979; Englund and others, 1986; Englund and Thomas, 1990; Milici, Freeman, and Bragg, 2001). Englund and others (1986) showed that the formation was deposited in a series of northwestward-prograding delta lobes. The Pocahontas coal beds apparently accumulated on the lobes of the paleodelta in several thick peat domes (up to $13 \mathrm{ft}$ thick after compaction), which in places have been mined extensively (Milici, Freeman, and Bragg, 2001). Shale-dominated interlobe areas contain relatively thin, discontinuous coal beds.

Because of its high gas content, the mined areas in the Pocahontas No. 3 coal bed contain many gob wells. Some of these gob wells had their origin as vertical ventilation holes that had vented methane into the atmosphere in advance of mining prior to 1988 , when CBM was first produced economically in Virginia (Nolde, 1995). Elsewhere, in unmined areas, numerous wells have been completed within the Pocahontas No. 3 coal bed, as well as in several of the overlying coal beds (fig. 18).

\section{New River Formation}

The New River Formation is 1,400 to $1,750 \mathrm{ft}$ thick in southwestern Virginia and southern West Virginia. It contains up to 16 named coal beds (fig. 18), many of which have produced CBM (Nolde, 1994a; Nolde and Spears, 1998). In Virginia, the New River is lithologically similar to the Pocahontas Formation, except that it contains several widespread, thick beds of quartzose sandstone and quartz-pebble conglomerate (tongues of the Lee Formation) in the western part of the coal field (Englund and Thomas, 1990; Nolde, 1994a). Nolde (1994a) regarded the New River as transitional between the 


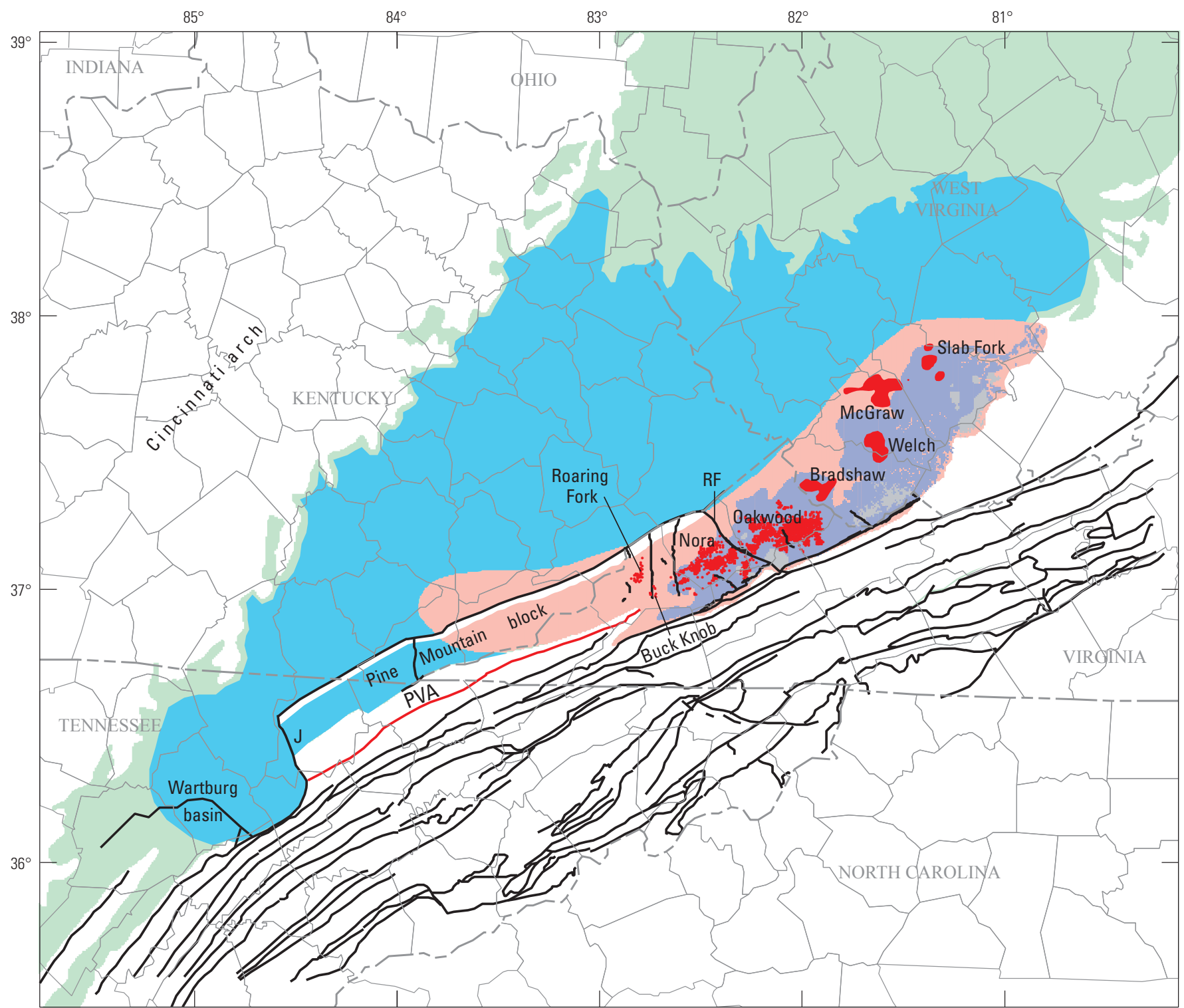

\section{EXPLANATION}

Part of the Appalachian basin coal region

Pocahontas Basin Assessment Unit

Pocahontas No. 3 coal bed, coal $>14$ inches thick

Pocahontas No. 3 coal bed, coal $<14$ inches thick

\section{Central Appalachian Shelf Assessment Unit}

\section{Appalachian thrust fault}

Trace of Powell Valley anticline (PVA)

Coalbed-methane field

Figure 16. Map of the central Appalachian basin coal region showing the Pocahontas Basin and Central Appalachian Shelf Assessment Units, major coalbed-methane (CBM) fields, and the Pocahontas No. 3 coal bed. CBM fields for Virginia from unpublished Wellsum database compiled from the files of the Virginia Division of Gas and Oil by Jack E. Nolde (consulting geologist, 2002-2007). CBM fields for West Virginia from Avary

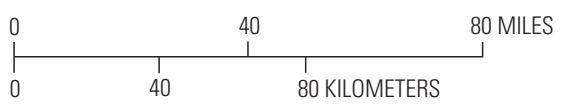

(2004). Data on the Pocahontas No. 3 coal bed from Milici, Freeman, and Bragg (2001, figs. 2 and 5). Thrust faults from Hardeman and others (1966), Virginia Division of Mineral Resources (1993), Schruben and others (1994), Roen and Walker (1996), and Kentucky Geological Survey (2006). J, Jacksboro fault; PVA, Powell Valley anticline; RF, Russell Fork fault. See figures 22 and 23 of this report for selected county names. 
quartzose sandstones and conglomerates of the Lee Formation and the subgraywacke sandstones of the overlying Norton Formation (fig. 17). Marine fossils have been reported from near the base of the New River in Virginia (Arkle and others, 1979; Englund, 1979; Nolde, 1994a).

\section{Kanawha Formation}

The Kanawha Formation is a unit in West Virginia that is equivalent to the upper part of the Norton Formation, the Gladeville Sandstone, and the Wise and Harlan Formations in Virginia (Nolde, 1994b) (fig. 17); the Kanawha consists of as much as $2,100 \mathrm{ft}$ of subgraywacke sandstone, shale, and mudstone. It contains several marine limestones and shale beds that contain marine to brackish-water invertebrates. In some places, marine zones consist of 100-ft-thick coarseningupward units of fossiliferous shale, siltstone, and sandstone that are widespread across the basin (Blake and others, 1994). Offshore facies consist of dark-gray, fossiliferous laminated shales. Nearshore and littoral deposits are interlaminated to interbedded shales, siltstones, and sandstones that exhibit the flasered bedding of tidal sedimentary environments. These beds may contain inarticulate brachiopods and a variety of shallow-water trace fossils (Martino, 1994). In West Virginia, several wells in the War Eagle, Gilbert, and Douglas coal beds within the lower part of the Kanawha Formation have been completed locally for CBM production (Avary, 2004).

\section{Lee Formation}

In Virginia, southern West Virginia, and eastern Kentucky, the Lee Formation is of Late Mississippian and Early Pennsylvanian age and consists of 800 to $1,650 \mathrm{ft}$ of quartzose sandstone and quartz-pebble conglomerate formations that are interstratified with coal-bearing shale, siltstone, and sandstone units. The Lee is in part equivalent to the Bluestone Formation (Late Mississippian to Early Pennsylvanian) and to the Pocahontas, Norton, and New River Formations of Early Pennsylvanian age (fig. 17) (Englund, 1979; Englund and Thomas, 1990; Nolde, 1994a).

There are several interpretations concerning the depositional environment of the Lee Formation. Ferm (1974) concluded that the Lee Formation was deposited as a northwestward-migrating beach and back-barrier complex; similarly, Englund (1979, p. C18) interpreted the depositional environments of the Lee and the overlying New River Formation as being "dominated by coastal and near-coastal deltaic processes." Rice and others (1979, p. F17), however, suggested "that the sandstone members of the Lee Formation were large sand-filled distributary channels of a dominantly southwestprograding delta." More recently, Greb and Chesnut (1996) described the Lee in Kentucky as consisting of multistory braided fluvial sand bodies, which are capped by estuarine sand facies, coal, and then by carbonaceous shales that contain marine or brackish-water fauna. Regardless of its interpreted depositional environment, the Lee Formation is time transgressive and becomes progressively younger to the northwest.

In general, the Lee Formation does not contain an abundance of coal beds, except in the deeper part of the basin. There, in the central part of the Virginia coal field, many of the coal beds recognized within the New River Formation (fig. 18) extend laterally into the Lee Formation (Nolde, 1994a), where wells are drilled and completed for CBM production.

\section{Norton Formation}

In Virginia, the Norton Formation generally overlies the Lee Formation conformably and consists of as much as $1,970 \mathrm{ft}$ of gray shale, siltstone, and lesser amounts of feldspathic and micaceous sandstone (Englund, 1979; Nolde, 1994a; Nolde and Spears, 1998). At least four beds within the Norton contain fresh- or brackish-water fossil invertebrates. The fossiliferous beds generally consist of 5 to $10 \mathrm{ft}$ of darkgray shales, which in places contain thin beds, lenses, or nodules of limestone. The Norton Formation is widely distributed in southwestern Virginia and contains 20 coal beds (more or less) in which wells may be completed for CBM production. These coal beds include most of those shown in figure 18, as well as the overlying Raven, Aily, Kennedy, Big Fork, Lower Banner, Upper Banner, Splash Dam, Hagy, and Norton coal beds.

\section{Gladeville Sandstone}

The Gladeville Sandstone consists of about 75 to $120 \mathrm{ft}$ of quartzose to feldspathic sandstone (Englund, 1979; Nolde, 1994a; Nolde and Spears, 1998). It overlies the Norton Formation with a conformable but sharp contact and is, in turn, overlain by the Wise Formation (fig. 17).

\section{Wise Formation}

The Wise Formation (fig. 17) is as thick as 2,268 ft (Miller, 1969) and is composed of fine- to coarse-grained siliciclastic strata, predominantly siltstone and sandstone. Shale beds that occur above several of the coal beds may contain invertebrate fossils. The Wise contains two widespread marine zones: the Kendrick Shale of Jillson (1919) and the Magoffin Member of the Wise Formation (Miller, 1969) (originally, the Magoffin Beds of Morse, 1931). In Virginia, the Kendrick Shale ranges from 10 to $20 \mathrm{ft}$ in thickness, is dark gray to black, and contains calcareous lenses with cone-in-cone structures and brackish-water to marine fossils. The Magoffin Member consists of 20 to $30 \mathrm{ft}$ of fossiliferous gray shale, thin beds of limestone, and calcareous siltstone (Nolde, 1994a).

Coal beds in the lower part of the Wise Formation include the Dorchester, Lyons, Blair, Clintwood, and Addington. Coal beds higher in the section are not widely distributed in this mountainous terrain and have little chance for development of CBM resources. 


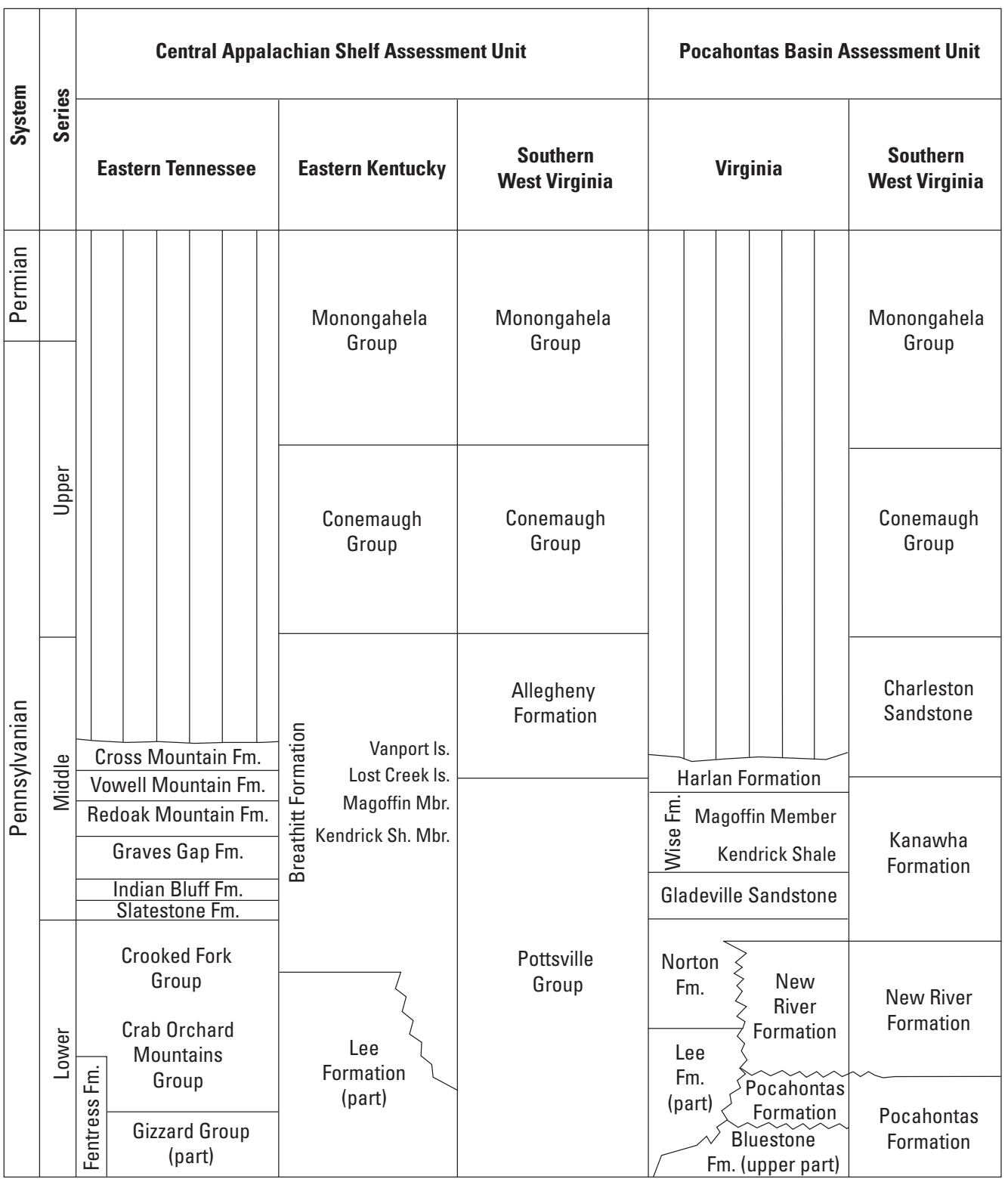

Figure 17. Chart showing generalized stratigraphic nomenclature for Pennsylvanian and Permian units in the central Appalachian basin coal region. Names are mostly from Arkle and others (1979), Englund (1979), Milici and others (1979), and Rice and others (1979). Abbreviations: Fm., Formation; Ls., Limestone; Mbr., Member; Sh., shale.

\section{Harlan Formation}

The Wise Formation is overlain by the Harlan Formation, which is the uppermost Pennsylvanian formation in Virginia (fig. 17). The Harlan is thickest on the mountaintops along the State line near Kentucky, where it consists of about $650 \mathrm{ft}$ of sandstone with minor amounts of siltstone and shale and several beds of coal (Englund, 1979).

\section{Breathitt Formation}

The Breathitt Formation overlies the Lee Formation throughout much of the eastern Kentucky coal field; both formations were included in the Breathitt Group by Chesnut (1992). It ranges from as much as 3,000 ft in thickness in southeastern Kentucky, where it is only partly preserved, to about $800 \mathrm{ft}$ in thickness in northeastern Kentucky, where it is overlain by the Conemaugh Formation (Rice and others, 1979). The Breathitt consists of shale, siltstone, impure sandstone (subgraywackes), coal, limestone, and ironstone. It contains about 30 minable coal beds or coal zones. Shales and siltstones are commonly carbonaceous and contain plant fossils. Marine fossils occur in some thin zones.

The Kendrick Shale of Jillson (1919), the Magoffin Member, and the Lost Creek Limestone of Morse (1931) are major marine zones that serve to subdivide the Breathitt locally. These zones are as thick as $115 \mathrm{ft}$ and represent regional marine transgressions that apparently were deposited in large, open bays (Rice and others, 1979). Relatively thin and locally distributed marine zones occur throughout the Breathitt, and these may represent local bay-fill or estuarine deposits. 


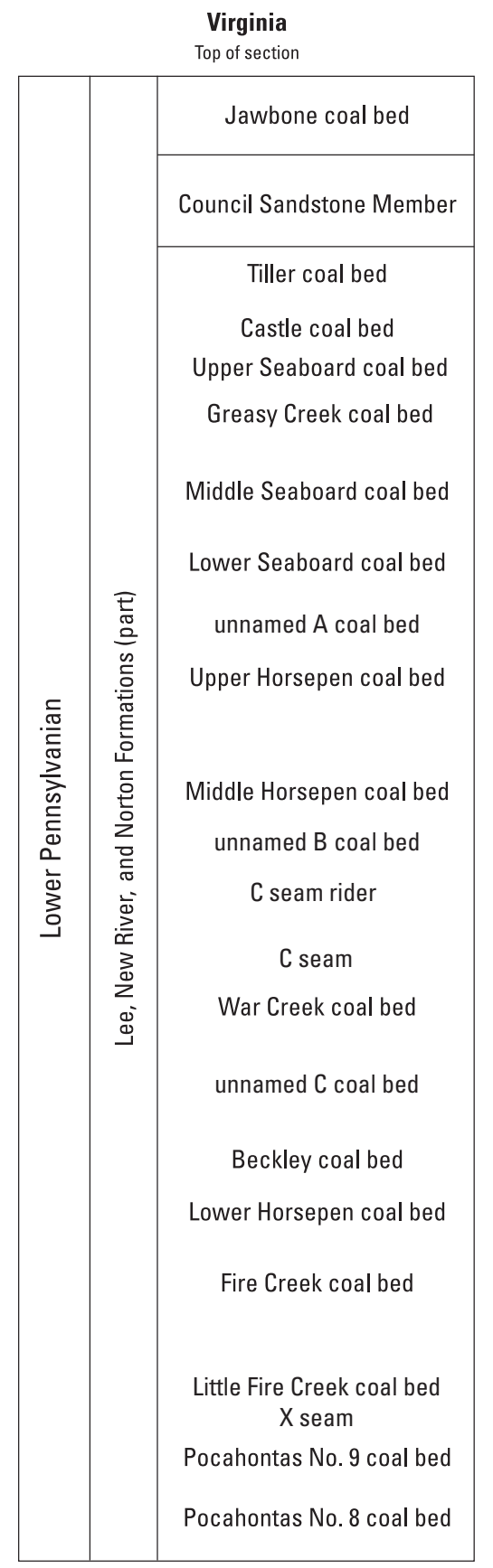

Continues at top of third column

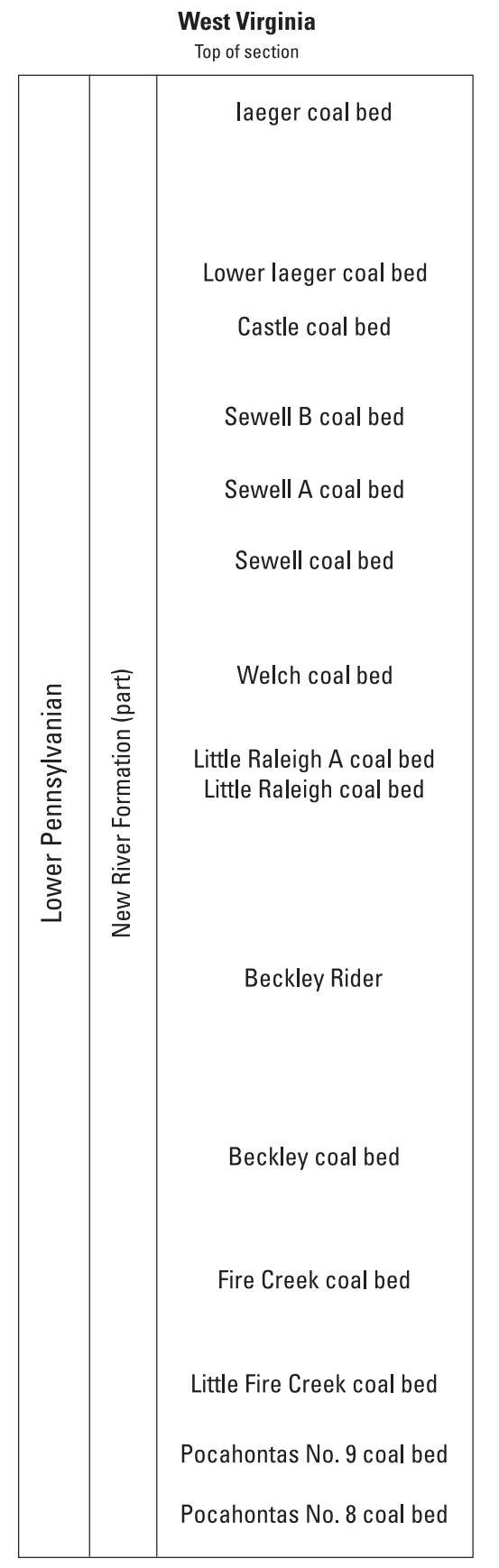

Continues at top of third column

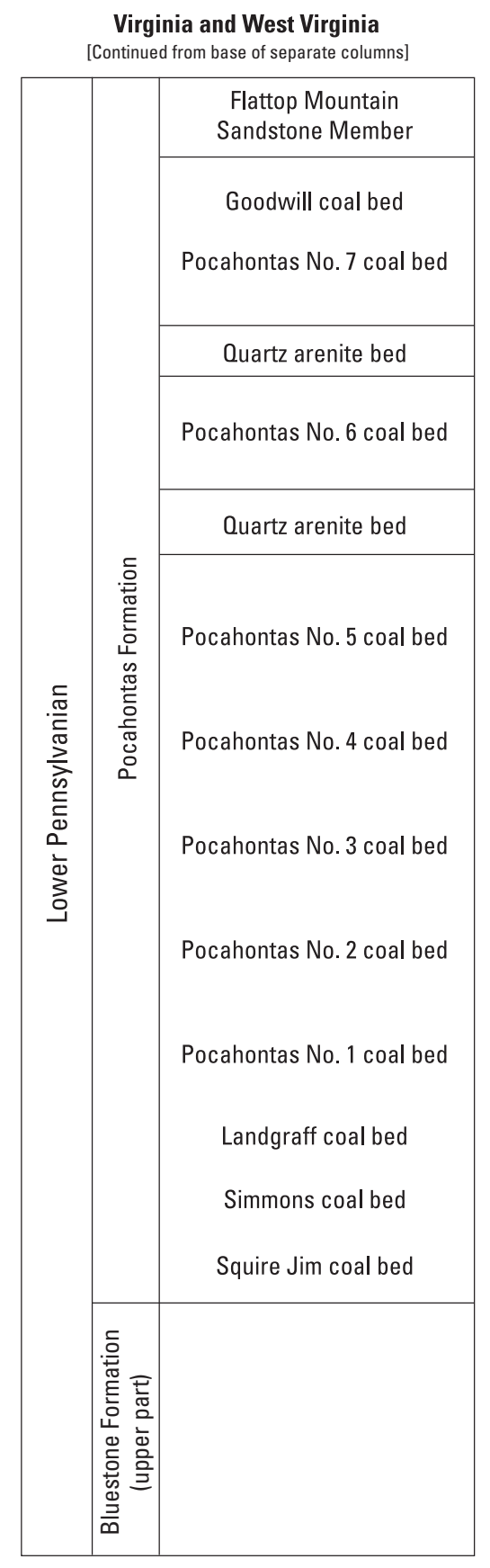

Base of section

Figure 18. Chart showing stratigraphic nomenclature for Lower Pennsylvanian formations, sandstones, and selected coal beds in coalbed-methane (CBM) fields in the Pocahontas Basin Assessment Unit of southwestern Virginia and adjacent West Virginia. The selected coal beds listed include those in which wells have been completed for CBM. Data from Arkle and others (1979), Englund (1979), Nolde (1994a,b), and Milici, Freeman, and Bragg (2001). The Pocahontas Basin Assessment Unit is shown in figures 16, 20 , and 21. 
Several wells have been successfully completed in the Breathitt Formation for CBM production in Clay and Bell Counties, Ky. (table 1) (Kentucky Division of Oil and Gas Conservation, 2004). These wells were probably completed in Lower Elkhorn coals (Brandon Nuttall, Kentucky Geological Survey, written commun., 2001).

\section{Geologic Structure}

In general, the major geologic structures of the central Appalachian basin coal region are (1) the regional dip to the southeast from the Cincinnati arch into the basin and (2) the Pine Mountain block (Cumberland Overthrust block) in Tennessee, Virginia, and eastern Kentucky (fig. 19). Numerous other structures have been mapped in this area and have been summarized by Harris and Milici (1977) and, more recently, by Chesnut (1992) and Henika (1994).

The Pine Mountain block is a major Alleghanian structure that is terminated on its ends by cross faults: the Jacksboro fault in Tennessee and the Russell Fork fault in Virginia. To the southeast, the block is bounded by the Powell Valley anticline, which was formed above a major structural ramp that transferred displacement from a décollement in the underlying Rome Formation (Cambrian) up into Paleozoic shales of Silurian and Devonian age.

Young (1957) documented explosive gas production that resulted from drilling into deformed and greatly fractured Devonian black shale at the base of the Pine Mountain block in southwestern Virginia. Gas production in these wells, which were drilled with cable tools, was almost instantaneous, and in many cases blew the drilling tools up the hole. Similarly, Harris and Milici (1977) described bedding décollements in coal beds and associated fracture systems in their hanging walls from extensive exposures in southern Tennessee. Subsequently, Milici and others (1982), Milici and Gathright (1985), and Milici and others (1986) documented décollements in southwestern Virginia that were localized within coal beds and associated shales, either in shale partings within the coal beds or in shale beds immediately overlying the coal beds. Henika (1994) provided additional examples of coal-bed décollement. Without question, décollement in hydrocarbon-rich rocks, whether black shales or coal beds, is a mechanism that may enhance porosity in these rocks. Where deformation is great, however, the gas may be released explosively and production will be short lived, as it was beneath the Pine Mountain block. Where deformation is slight or moderate, however, production may be enhanced by additional networks of fractures that intersect joints in shales or cleats in coal, as it may be in some $\mathrm{CBM}$ reservoirs in the Pocahontas basin.

\section{Coalbed-Methane Fields}

For the purposes of this report, the principal CBM accumulations in the Pocahontas basin in Virginia are grouped into the Buck Knob field in Wise County and the Nora and Oakwood fields (fig. 16). The Nora field is mostly in Dickenson and Russell Counties, whereas the Oakwood field is mostly in Buchanan and Tazewell Counties. In West Virginia, the named fields are the Bradshaw, Welch, McGraw, and Slab Fork fields (fig. 16). Jack E. Nolde, consulting geologist, compiled unpublished Virginia well data from the files of the Virginia Division of Gas and Oil into his unpublished Wellsum database (2002-2007); these data were used in the USGS National Oil and Gas Assessment in 2002. Avary (2004) compiled the data for West Virginia.

Lewis (1999) described the Buck Knob anticline field thusly:

The Buck Knob anticline of Wise County represents the southwestern extent of coalbed methane production in Virginia. ... Approximately 400 feet of structural closure is expressed at the Pennsylvanian level.

... Reservoirs belong to the Norton and Lee Formations (Morrowan) and range from 650-2450 feet in depth. The coals are of high volatile A to medium volatile bituminous rank. Gas contents range from 60-150 scf/ton [standard cubic feet per short ton]. A typical completion contains 6 coal seams with an aggregate thickness of 120 inches. ...

Average open flow is $50 \mathrm{MCFPD}$. Average peak rate is 95 MCFPD and is reached within 9-12 months. Exceptional wells have production rates above 200 MCFPD. Current field rate exceeds 1500 MCFPD. Estimated ultimate recoveries are $425 \mathrm{MMCF}$ per well based on 80 acre spacing. Total field recoveries are expected to reach 25-30 BCF.

The natural fractures in the Buck Knob field may be related to interstratal slip along the limbs of the fold or to limited bedding décollement within the coal beds that occurred before and during folding. Target coal beds are in the Lee, Norton, and Wise Formations, and depths to the tops of completed zones range from about 635 to 2,480 ft. In recent years, CBM production from Wise County, Va., which was mostly from the Buck Knob field, has declined from 1.1 BCF in 1999 (62 wells) to 978.5 MMCF in 2001 (67 wells) (Virginia Center for Coal and Energy Research, 2004).

CBM production in Buchanan County, Va., was mostly from the Oakwood field; it appears to have peaked in 2000 at 41.7 BCF (1,328 wells) and was down a little, to 41.5 BCF, in 2001 (1,696 wells) (Virginia Center for Coal and Energy Research, 2004). Target beds in Buchanan County ranged from the Seaboard coal beds in the New River Formation or the Norton Formation down to the Pocahontas No. 1 coal bed in the Pocahontas Formation (fig. 18); the most wells were completed in the Pocahontas No. 3 coal bed. CBM was produced from gob in mined areas of the Pocahontas No. 3, as well as from the unmined coal, which was fractured and hydraulically stimulated in advance of mining. Although depths to the tops of completed zones in Buchanan County ranged from as little as $325 \mathrm{ft}$ to more than $2,400 \mathrm{ft}$, most of the completions were $1,000 \mathrm{ft}$ or more deep. 


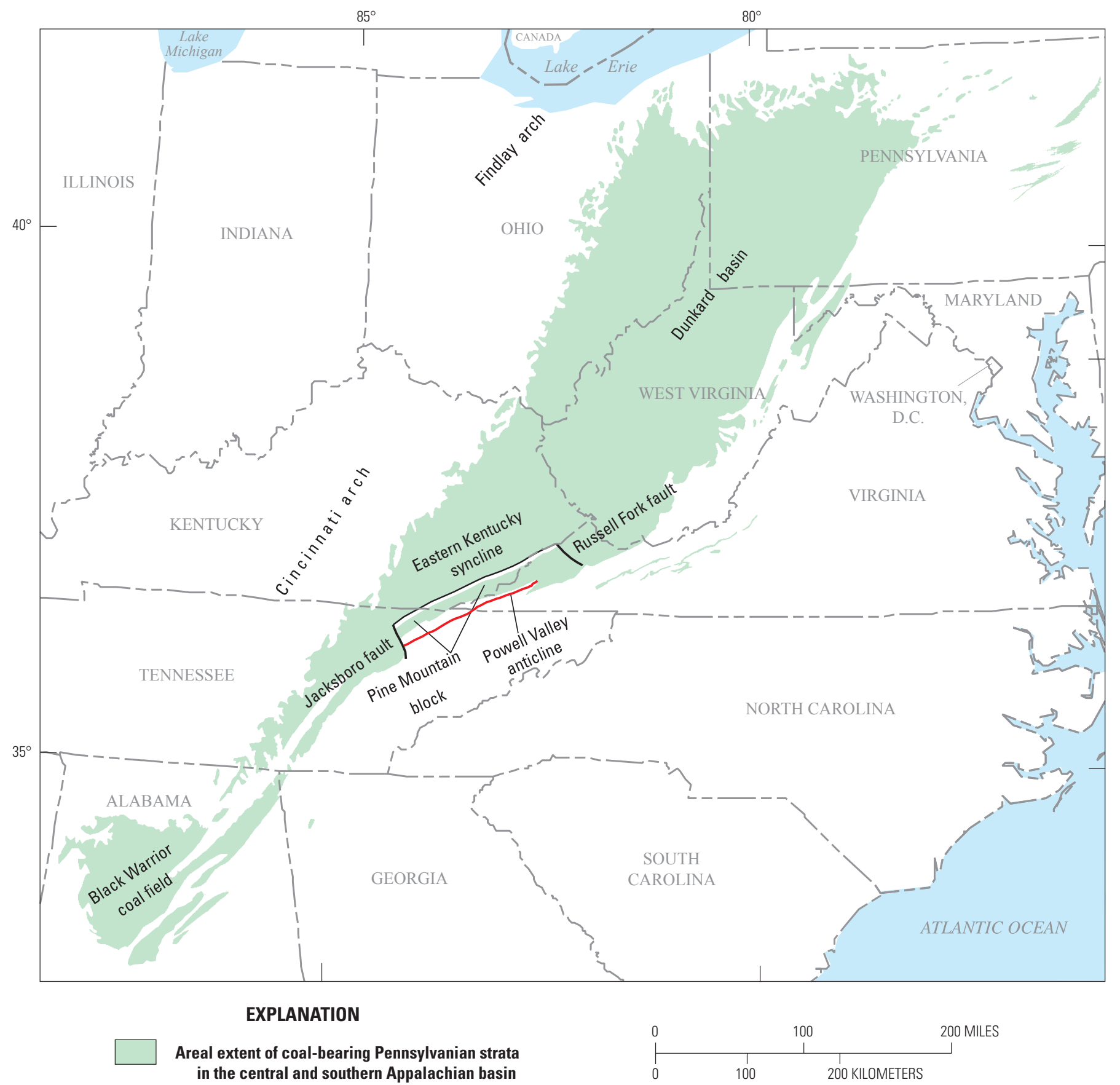

Figure 19. Map showing major structural elements of the central and southern parts of the Appalachian structural basin, including the Pine Mountain block, which is partly in the Pocahontas basin; see also figures 1, 16, and 20.

Dickenson County CBM production was mostly from the Nora field; it peaked in 1999 at 9.5 BCF (373 wells) and declined to $8.5 \mathrm{BCF}$ in 2001 (444 wells) (Virginia Center for Coal and Energy Research, 2004). Target coal beds were generally from the Jawbone to the Pocahontas No. 1 coal bed; most of the completions were within deeper coals of the Lee Formation. Depths to completed coal zones were, in places, as shallow as $375 \mathrm{ft}$. Most of the completions, however, have been effected at depths greater than $1,000 \mathrm{ft}$.
Production declines in Buchanan and Dickenson County, Va., were offset by new discoveries in Russell County, Va., in 2002, where CBM production increased from 484.5 MMCF (45 wells) in 2000 to 3.5 BCF (110 wells) in 2002. There, Pocahontas and Lee coals were commonly completed at depths that ranged from about 600 to $1,500 \mathrm{ft}$, or more. Altogether, Virginia's annual CBM production reached 58.6 BCF (2,235 wells) in 2002 (Virginia Center for Coal and Energy Research, 2004). 


\section{Coal as a Source Rock for Coalbed Methane}

\section{Gas-in-Place Data}

Within the Pocahontas Basin AU, maximum gas-in-place data by county range from $282 \mathrm{CF} /$ ton in Dickenson County to $688 \mathrm{CF} /$ ton in Buchanan County, Va. (fig. 20) (Diamond and others, 1986). One sample from Wyoming County, W. Va., yielded a value of $285 \mathrm{CF} / \mathrm{ton}$. The number of samples in Dickenson (4) and Wyoming (1) Counties is small, and their values almost certainly understate the in-place CBM potential for those counties. Gas-in-place values for the Central Appalachian Shelf AU are conspicuously smaller, and maximums by county range from a low of $54 \mathrm{CF} /$ ton in Perry County, Ky. (1 sample), to $144 \mathrm{CF} /$ ton in Mingo County, W. Va. (30 samples). In general, the area is undersampled, and the values shown in figure 20 understate the gas-in-place potential for the area, except perhaps for Mingo County.

\section{Thermal Maturity}

The $0.8-\% \mathrm{R}_{\mathrm{o}}$ isoline illustrated in figure 21 is based on a composite of all vitrinite reflectance data for the area, which were derived from core and outcrop samples of numerous coal beds. Areas where vitrinite reflectance values are less than 0.8 percent are generally west of the isoline and are considered to be relatively immature with respect to thermogenic gas generation; areas where vitrinite reflectance values are equal to or greater than 0.8 percent are generally east of the isoline and are considered to be mature with respect to commercial gas generation. Although all of the coal samples to the west of the $0.8-\% \mathrm{R}_{\mathrm{o}}$ isoline are immature, coal samples to the east of the isoline show a mixture of both mature and immature values.

In general, coal rank (and thermal maturity) varies with maximum depth of burial. For example, the apparent rank of the Pocahontas No. 3 coal bed in the deeper part of the Pocahontas basin ranges from high-volatile A bituminous coal to semianthracite (fig. 22) (Milici, Freeman, and Bragg, 2001). In contrast, the rank of the stratigraphically higher Fire Clay coal zone (Tewalt, Ruppert, Bragg, Weisenfluh, and others, 2001), which is in the Wise Formation (Virginia) and Breathitt Formation (eastern Kentucky) on the shelf to the west (figs. 17 and 23), is almost entirely high-volatile A bituminous.

\section{Generation and Migration}

Microbial methane almost certainly was generated during the accumulation of peat during the Pennsylvanian, and generation may be continuing today where shallow coal beds interact with surface waters. Thermal maturation commenced toward the end of the Paleozoic in the deep Pocahontas basin, probably to the northeast near the Appalachian Valley and Ridge Province, where semianthracite occurs in the Pocahontas No. 3 coal bed at depth. Structural deformation (and perhaps structural loading) in the Valley coal fields of
Virginia, 30 to $50 \mathrm{mi}$ to the east and north of the Pocahontas basin, has metamorphosed the Mississippian-age coal there to semianthracite (Campbell and others, 1925). Thermal maturity (vitrinite reflectance values equal to or greater than 0.8 percent) was probably reached in the Pocahontas basin during the latest Paleozoic and earliest Mesozoic, prior to early Mesozoic uplift and erosion (fig. 15).

\section{Coal as a Reservoir for Coalbed Methane}

\section{Porosity and Permeability}

Porosity and permeability of natural cleat systems in coal beds in the Pocahontas basin have been enhanced by structural deformation and limited décollement within coal beds on and near the Pine Mountain block (Milici and others, 1982, 1986). In general, deep coal beds in the Pocahontas basin contain less water than the coals in the northern Appalachian basin coal region, and production rates and yields per well are generally greater in the Pocahontas basin than in the Dunkard basin.

\section{Coal-Bed Distribution}

In general, coal beds suitable for the development of CBM are $\geq 500 \mathrm{ft}$ deep in the Pocahontas basin, are $\geq 14$ inches thick, are charged with thermally generated methane, and are not mined extensively. Nolde and Spears (1998) presented maps of 10 coal beds in the Pocahontas basin of Virginia that occur at depths of $500 \mathrm{ft}$ or more from the Upper Seaboard down to the Pocahontas No. 3 coal bed (fig. 18). Similar data were compiled by the USGS for the Fire Clay and Pond Creek coal beds, which are mostly in the Central Appalachian Shelf AU, and for the Pocahontas No. 3 coal bed in the Pocahontas Basin AU (Milici, Freeman, and Bragg, 2001; Ruppert and others, 2001; Tewalt, Ruppert, Bragg, Weisenfluh, and others, 2001). These USGS reports include maps of the coal-bed extent and mined-out areas, coal isopachs, structure contours, and depth of overburden, which collectively provide the geological framework for CBM exploration and development in those areas.

Drahovzal and others (2002) designated an area in eastern Kentucky centered about the eastern Kentucky syncline (fig. 19) as having the best potential for CBM development in the Central Appalachian Shelf AU. This area contains as much as $1,500 \mathrm{ft}$ of Pennsylvanian strata and as much as 30 $\mathrm{ft}$ of cumulative coal thickness, with the thickest overburden and the highest rank coals in eastern Kentucky (Drahovzal and others, 2002).

\section{Cumulative Coal Thickness}

In general, in the Pocahontas Basin AU, CBM wells are commonly completed in several coal beds and penetrate a cumulative coal thickness of 15 to $25 \mathrm{ft}$. However, where the vertical ventilation holes that were drilled into a coal bed 


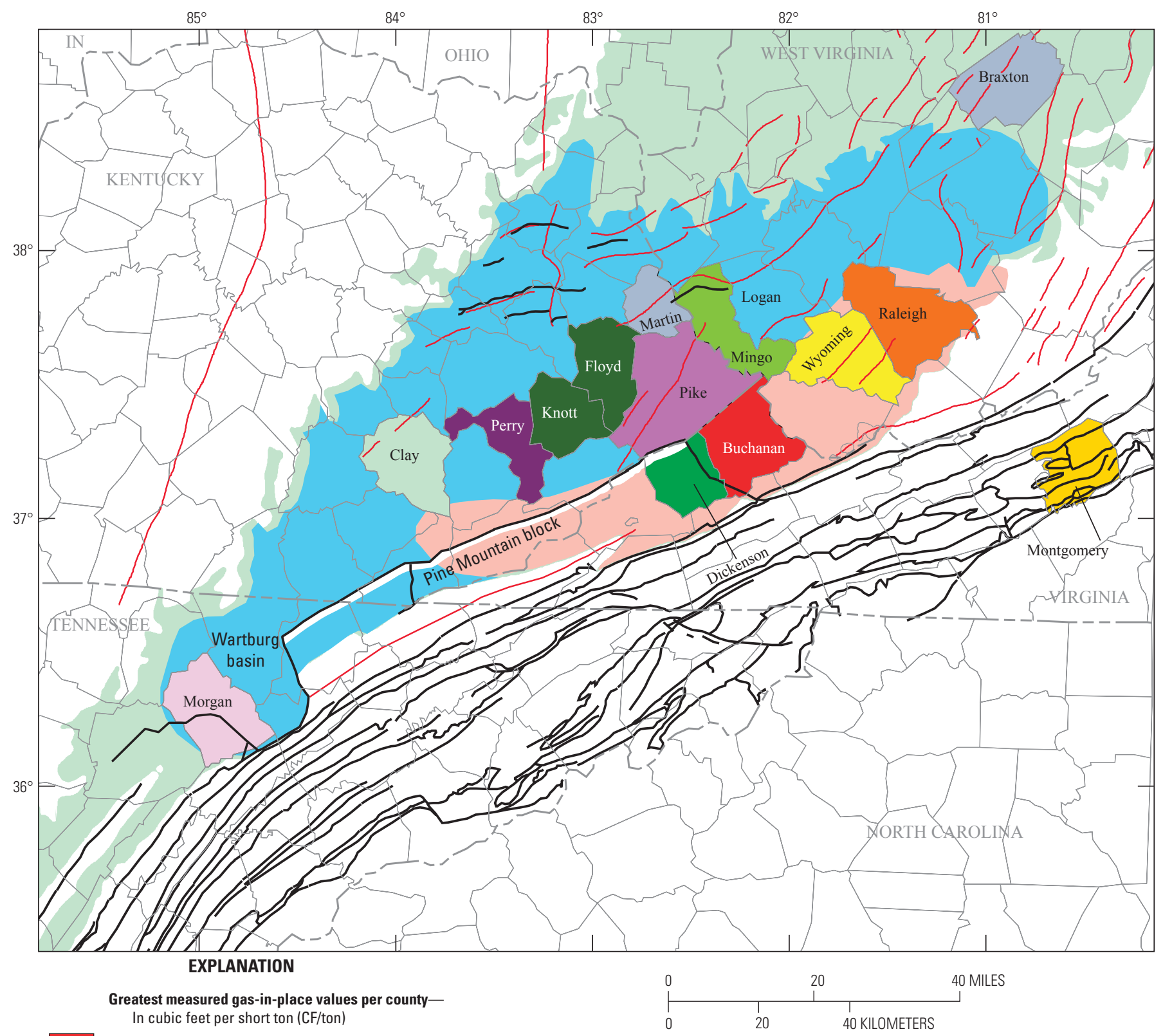

$688, n=24$

$490, n=13$

$394, n=12$

$285, n=1$

$282, n=4$

$144, n=30$

$128, n=3$

96, $n=7$ (Knott), 3 Floyd)

90, $n=1$ (Martin), 19 (Braxton)

$83, n=3$

$67, n=2$

$54, n=1$

Part of the Appalachian basin coal region

Pocahontas Basin Assessment Unit

Central Appalachian Shelf Assessment Unit

Appalachian thrust fault

Trace of anticline axis

Figure 20. Map showing a direct measurement of gas-in-place content in coal beds for selected counties in and near the Central Appalachian Shelf and Pocahontas Basin Assessment Units, which are in the central Appalachian basin coal region (fig. 1). Largest measured gas-in-place content in cubic feet per short ton (CF/ton) is plotted on map for each county. Data on gas content from Diamond and others (1986). $n$, number of samples. Faults and traces of anticline axes from Hardeman and others (1966), Virginia Division of Mineral Resources (1993), Schruben and others (1994), Roen and Walker (1996), and Kentucky Geological Survey (2006). 


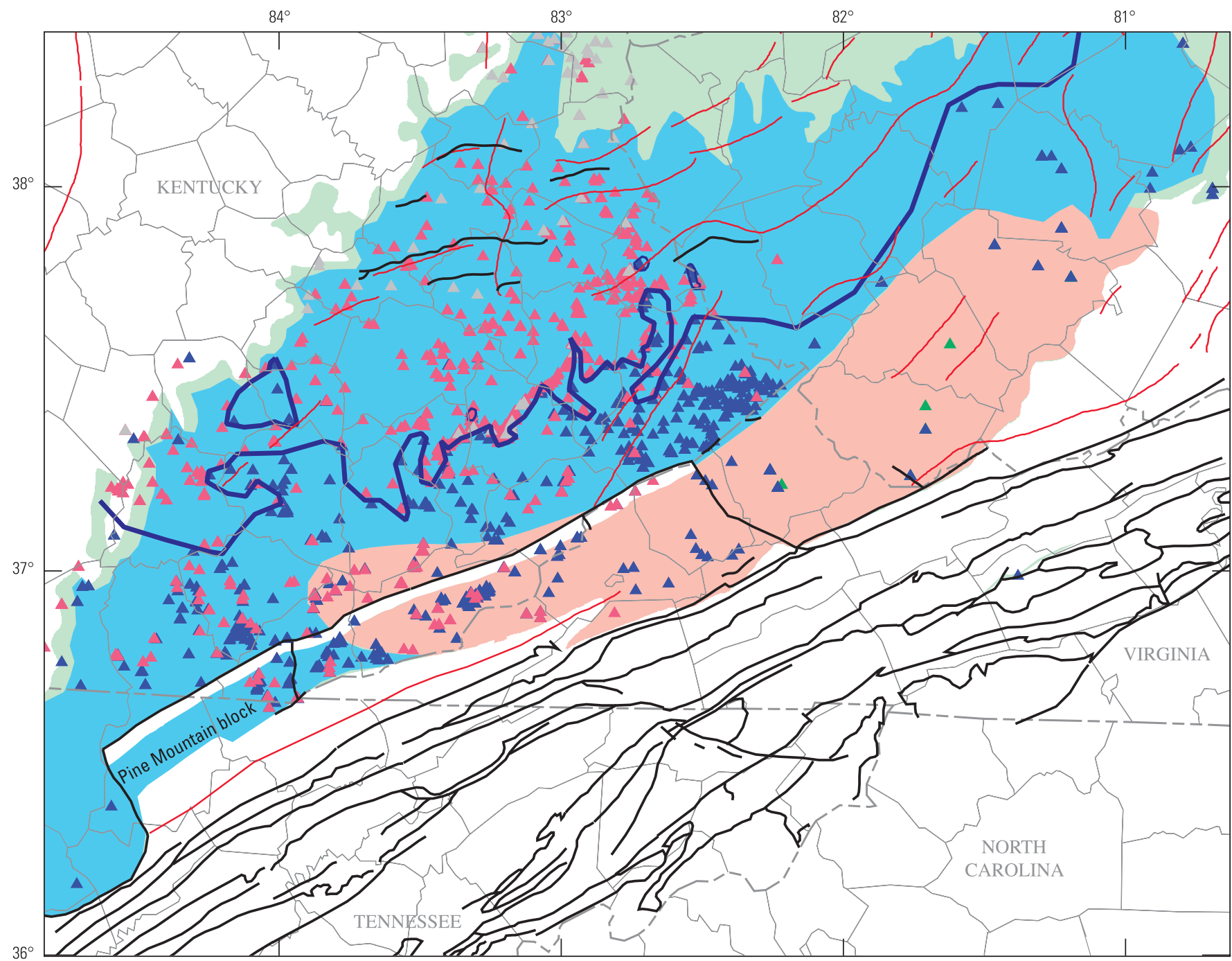

EXPLANATION
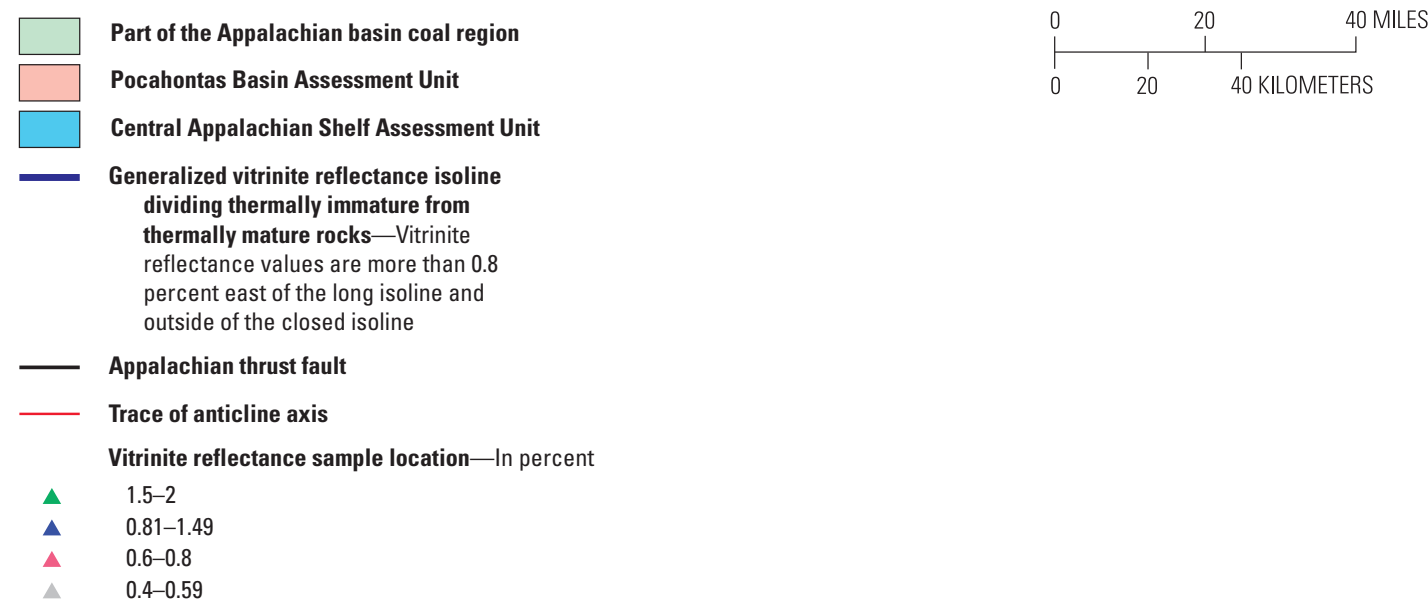

Figure 21. Map showing thermal maturation data for the central Appalachian basin coal region. The generalized vitrinite reflectance $\left(R_{0}\right)$ isoline of 0.8 percent separates thermally immature coal beds on the west from coal beds on the east that are immature to mature with respect to gas generation. Unpublished vitrinite reflectance data provided by Leslie Ruppert (U.S. Geological Survey) in 2002. 


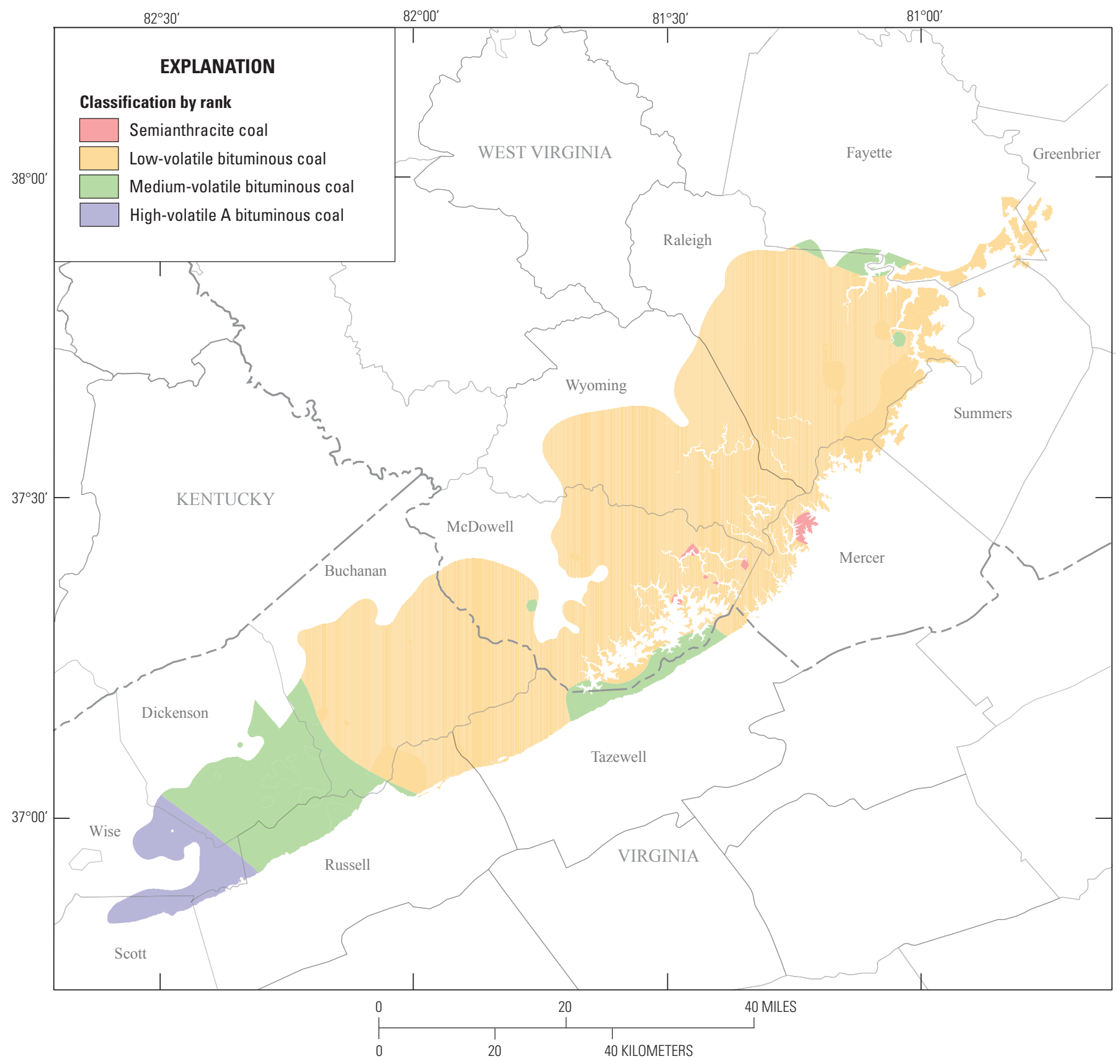

Figure 22. Map showing the extent and apparent rank of the Pocahontas No. 3 coal bed in Virginia and West Virginia based on 125 analyses. Figure from Milici, Freeman, and Bragg (2001, fig. 3). The coal tends to increase in rank from high-volatile $A$ bituminous in the southwest to low-volatile bituminous in the northeast; small bulls-eye-shaped pods of semianthracite are observed at the eastern limit of the coal bed along the Allegheny structural front in McDowell and Mercer Counties, W. Va. Methodology for rank determinations was based on the percentage of fixed carbon in the sample. When dry, mineral-matter-free (dmmf) fixed carbon was $>69$ weight percent, rank was determined on dmmf fixed carbon; when dmmf fixed carbon was $<69$ weight percent, rank was determined from moist, mineral-matter-free gross calorific values (American Society for Testing and Materials, 1996). 


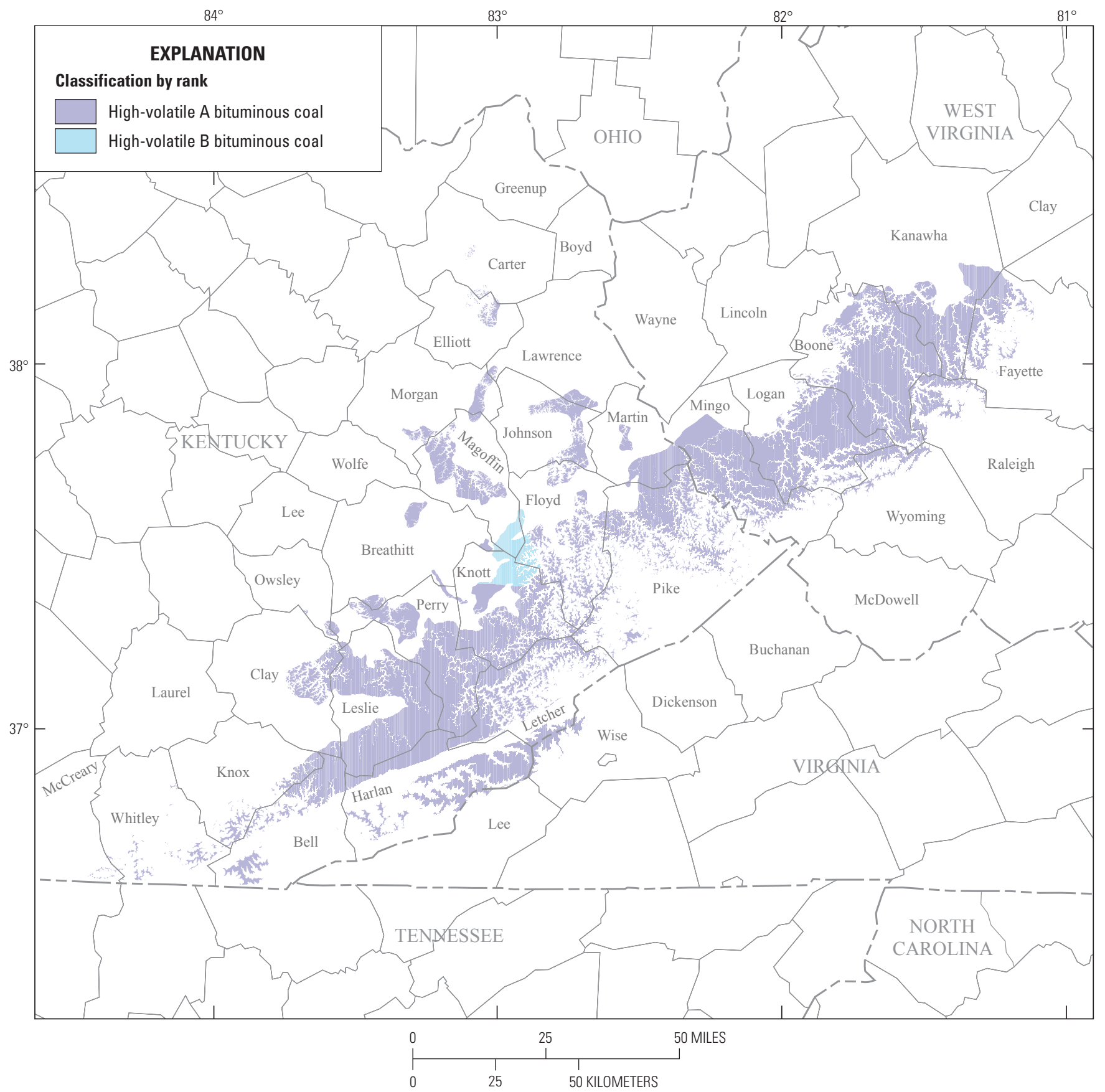

Figure 23. Map showing the extent and apparent rank of the Fire Clay coal zone in Kentucky, Virginia, and West Virginia based on 55 analyses. Figure modified slightly from Tewalt, Ruppert, Bragg, Weisenfluh, and others (2001, fig. 24). The coal is almost entirely high-volatile A bituminous. Only gross calorific values were used to determine the rank of the Fire Clay coal zone. The one area shown as high-volatile $B$ bituminous rank reflects a decreasing trend in moist, mineral-matter-free (mmmf) gross calorific values, but it is based on only one analysis and may be invalid. 
for mine safety (degasification) purposes were converted to gob wells, only that one bed may produce gas. As cited in the section above, the Central Appalachian Shelf AU contains sufficient coal within the eastern Kentucky syncline to permit as much as $30 \mathrm{ft}$ of coal to be completed in a single CBM test well (Drahovzal and others, 2002).

\section{Seals}

\section{Depth of Burial}

There is sufficient shale within the Pennsylvanian section in the Pocahontas basin to serve as local seals (fig. 15). In many places, water within coal beds serves as an effective seal to gas migration, and gas may be produced from relatively shallow coal beds once the water is removed. Because of the relatively small amounts of water associated with CBM production in southwestern Virginia, however, the coal beds in which wells are completed for gas production generally are at depths that approach 1,000 ft (Nolde and Spears, 1998), and shallow coals in the upper part of the section may contain insufficient gas for development. In the Pocahontas basin, CBM is effectively produced from coal beds buried $500 \mathrm{ft}$ or more beneath the surface.

\section{Water Production}

Water production per well is relatively low in the Pocahontas basin. In general, in 2001, a sample of 1,718 wells produced an average of about 533 barrels of water per well per year. Average water production was somewhat greater in 1990, when a sample of 54 wells produced about 633 barrels of water (J.E. Nolde, unpub. Wellsum database, 2002-2007).

\section{Cumulative Production and Estimated Ultimate Recovery Data}

Deep production of coal-bed gas associated with the degasification and mining of the Pocahontas No. 3 coal bed provided the initial impetus for much of the CBM development in Virginia. Through 2006, the Pocahontas basin had produced about $754 \mathrm{BCF}$ of CBM (exclusive of pre-mine and mine drainage). About two-thirds of the CBM produced in the Pocahontas Basin AU was from Buchanan County, Va., which had produced about 510 BCF by 2006. Much of the remainder came from Dickenson County, Va. (121 BCF), Wyoming County, W. Va. (39.4 BCF), and Russell County, Va. (35.2 BCF) (table 1).

Production data are available for 14 years from the first nine wells drilled in the Pocahontas basin in Dickenson County, Va. (J.E. Nolde, unpub. Wellsum database). Second-year production averaged 34.1 MMCF; production declined sharply during years three and four $(1991,1992)$ to a little more than $25 \mathrm{MMCF}$ for economic reasons and then rebounded in the fifth year to 38.4 MMCF. By the 14th year, average yearly production for the wells had declined to 20.3 MMCF. Cumulative production ranged from 135.3 MMCF to 591.1 MMCF and averaged 376.5 MMCF per well for the nine wells over a 14-year production history.

\section{Assessment Results}

The area that is considered most likely to be developed during the next 30 years is coincident with that of the minimum petroleum system within the Pocahontas Basin AU, which includes the producing area in Virginia and West Virginia (fig. 16). In 2002, the USGS assessed this area (at the statistical mean) as containing about $3.58 \mathrm{TCF}$ of technically recoverable undiscovered methane (table 3) (Milici and others, 2003). This value is a little larger than the amount assessed by Rice and Finn (1996), who reported a mean undiscovered resource of about 3.07 TCF for the Central Appalachian Basin Play. Rice and Finn (1996), however, had little drilling and production information at the time of their assessment and used an analog assessment methodology.

\section{Appalachian Anthracite and Semi-Anthracite Assessment Unit: Pennsylvania Anthracite}

\section{Introduction}

The Pennsylvania Anthracite region is within the folded and faulted Appalachians in the Valley and Ridge and Appalachian Plateaus physiographic provinces (Fenneman, 1938). The four main fields in this mining district are the Southern, Western Middle, Eastern Middle, and Northern fields (fig. 24) (Wood and others, 1962, 1969, 1986). In general, the anthracite fields consist of Pennsylvanian strata that are complexly folded, faulted, and preserved in structural synclines within older Paleozoic strata.

Most of the historical anthracite production in Pennsylvania has been from the Northern and Western Middle fields (Eggleston and Edmunds, 1981). As of 2000, approximately 5.5 billion short tons (bst) had been produced from the Pennsylvania Anthracite region. Total remaining resources in synclines that may be as much as 5,000 ft deep are estimated to be about $19.6 \mathrm{bst}$, and the potential recoverable resource, down to depths of about $1,000 \mathrm{ft}$, is estimated to be about 7.3 bst. About 68 percent of the remaining resources are in the Southern field, 14 percent in the Northern field, 17 percent in the Western Middle field, and the remainder in the Eastern Middle field (Eggleston and Edmunds, 1981; Eggleston and others, 1999). 


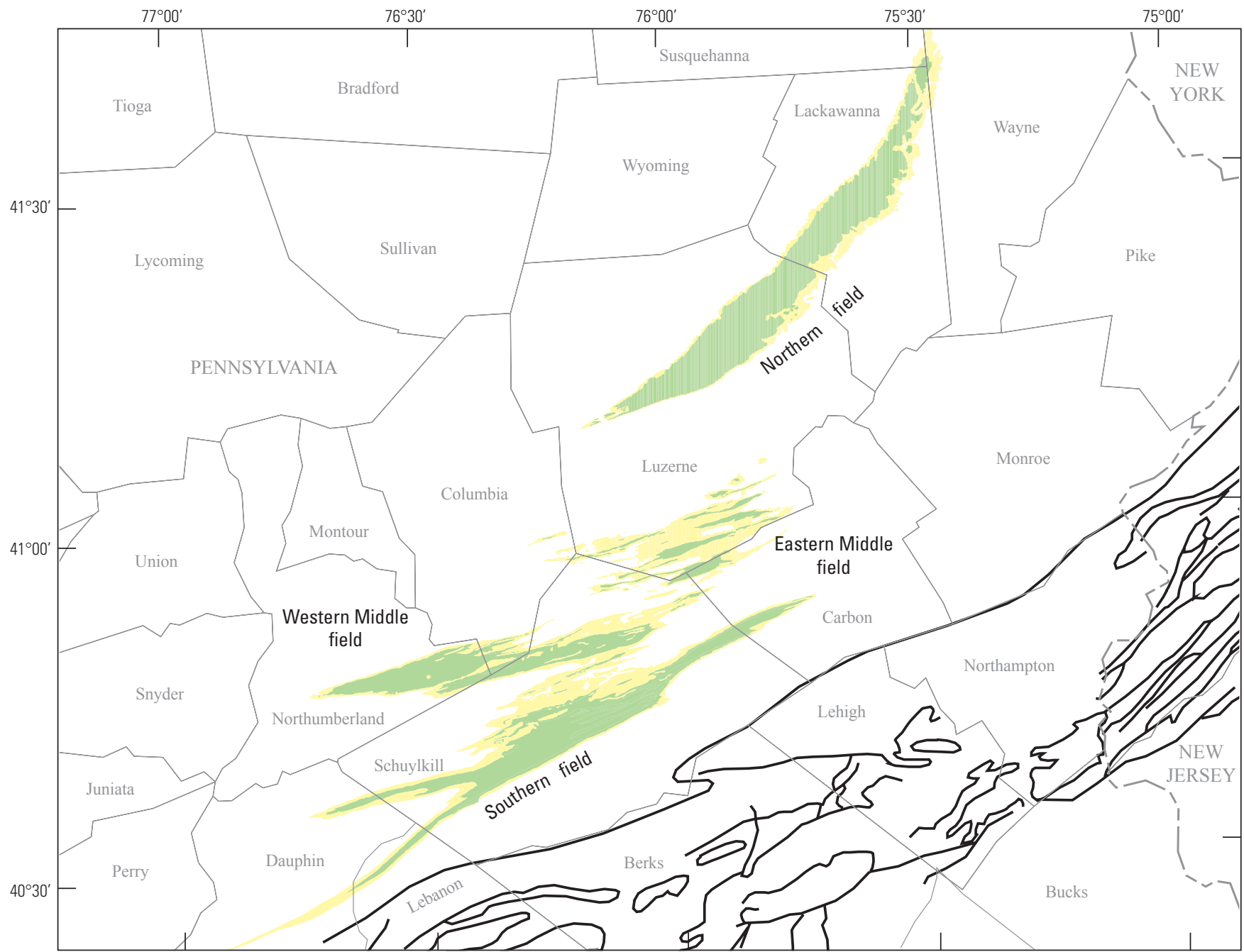

EXPLANATION

Anthracite coal field (Llewellyn Formation)

Anthracite coal field (Pottsville Formation)

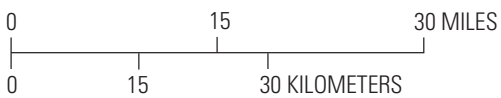

Appalachian thrust fault

Figure 24. Map showing location and generalized geology of the Pennsylvania Anthracite region (colored areas), which is within the Appalachian Anthracite and Semi-Anthracite Assessment Unit; see figure 1. Appalachian thrust faults from Berg and others (1980) and Schruben and others (1994).

The Appalachian Anthracite and Semi-Anthracite Assessment Unit is shown in figure 1. Although the assessment unit was defined in the 2002 USGS National Oil and Gas Assessment, its CBM resources have not been quantitatively assessed.

\section{Stratigraphy}

The Pennsylvanian stratigraphic section includes three formations in the Pennsylvania Anthracite region: the upper part of the Mauch Chunk Formation (Early Pennsylvanian), the Pottsville Formation (Early and Middle Pennsylvanian), and the Llewellyn Formation (Middle and Late Pennsylvanian) (fig. 25).

\section{Mauch Chunk Formation}

The Mauch Chunk Formation ranges from about 3,000 to $4,000 \mathrm{ft}$ in thickness in the Southern field and generally thins to the north and west across the Pennsylvania coal fields. In general, the formation contains mudstone, siltstone, sandstone, and conglomerate of various hues of red and brown, which 


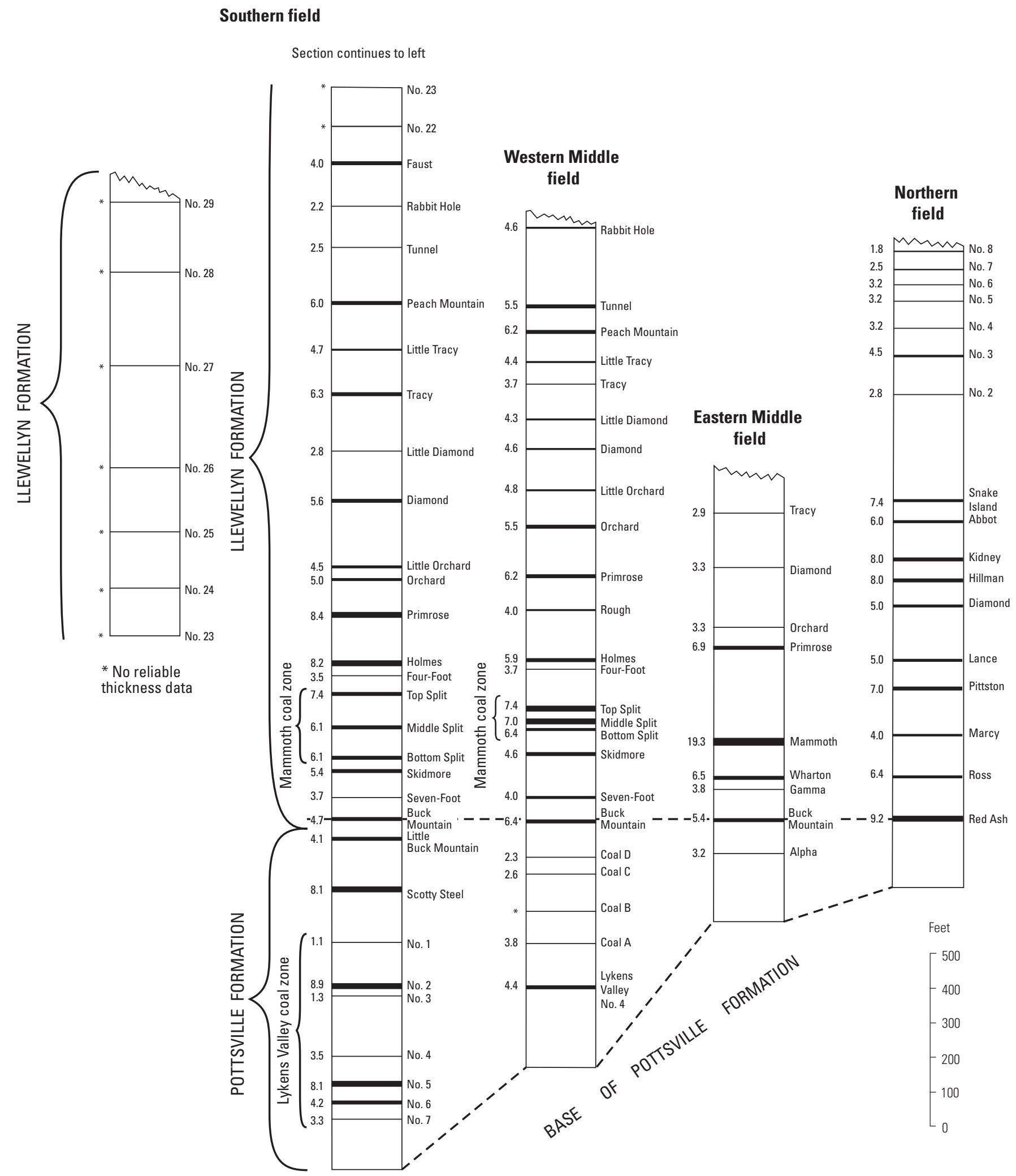

Figure 25. Generalized columnar sections showing the names of coal beds, the average thickness of each coal in feet, and the intervals between coal beds in the Southern, Western Middle, Eastern Middle, and Northern fields within the Pennsylvania Anthracite region. From Arndt and others (1968, fig. 45, p. 130). 
are interbedded with similar lithologies having gray and green colors. The Mauch Chunk apparently accumulated as floodplain deposits on a broad coastal plain. The upper part of the Mauch Chunk, which is about $650 \mathrm{ft}$ thick in the Southern field, is interbedded with the Pottsville and is classified with the Pottsville as Pennsylvanian in age (Wood and others, 1962, 1969; Edmunds and others, 1999).

\section{Pottsville Formation}

The thickness of the Pottsville Formation ranges from about 1,600 ft in the Southern field, where it contains about 14 coal beds, to less than $100 \mathrm{ft}$ in the Northern field, where it contains little or no coal (Edmunds and others, 1999; Eggleston and others, 1999). In the Pennsylvania anthracite region, the Pottsville Formation extends from the top of the red beds of the Mauch Chunk Formation (Mississippian) to the base of the clay bed or shale beneath the Buck Mountain (No. 5) coal bed (White, 1900). The Pottsville consists mostly of conglomerate, conglomeratic sandstone, and sandstone. Some of the conglomerates in the Pottsville and underlying Mauch Chunk Formation contain clasts of igneous and metamorphic rocks and minerals, which indicate that crystalline rocks were exposed in the source area (Wood and others, 1969). Only about 25 to 40 percent of the formation is siltstone, shale, and coal (Edmunds and others, 1999).

The Pottsville is entirely nonmarine in this area and is divided into three units: the Tumbling Run, Schuylkill, and Sharp Mountain Members. Each of these members consists generally of multiple fining-upward alluvial cycles, which contain conglomerates and conglomeratic sandstones at the base and shales and coal beds at the top (Wood and others, 1956, 1969).

\section{Llewellyn Formation}

The Llewellyn Formation overlies the Pottsville Formation. In general, the Llewellyn Formation extends from the base of the Buck Mountain (No. 5) coal bed to the present erosion surface. The formation consists predominantly of subgraywacke conglomerate and conglomeratic sandstone, sandstone, siltstone, shale, and coal, with local deposits of marine limestone. The maximum thickness of the Llewellyn Formation, about 3,500 ft, occurs in the central part of the Southern field. The formation is thinnest in the Eastern Middle field, where about $1,000 \mathrm{ft}$ are preserved.

There are about 40 coal beds in the formation that have been identified by both name and number (Wood and Trexler, 1968; Wood and others, 1968, 1969). Although the lateral distribution and thicknesses of rock units in the Llewellyn vary greatly from place to place, intervals between the major coal beds tend to be more consistent. In general, the thicker, more widespread coal beds occur in the lower $1,500 \mathrm{ft}$ of the Llewellyn (Wood and others, 1986).

\section{Geologic Structure}

The Pennsylvania Anthracite region consists of four major synclinoria that extend from within a tightly compressed, greatly folded and faulted part of the Appalachian Valley and Ridge province northwestward into the Appalachian Plateaus. In general, structural deformation, which is greatest in the Southern field, decreases to the northeast, so that the Northern field, which is in the Lackawanna basin, is the least deformed of the four (Wood and Bergin, 1970).

These superficial structures of the folded and faulted Appalachians are underlain by a basal décollement within the lower part of the Paleozoic section, from which major southeastward-dipping tectonic ramps splay upward, generally as blind thrusts, to where they "tip-out" in the overlying Paleozoic section. The anthracite region lies in structural lows adjacent to or between the major first-order ramp anticlines that were formed by movement along the splay thrusts (Faill, 1998). The Northern (Lackawanna) field, which is the least deformed of the four, is nestled between two first-order anticlines (Faill, 1998). Although there are no first-order anticlines in the Southern, Western Middle, and Eastern Middle fields, this area is one of the most severely deformed, relatively large regions of the Valley and Ridge.

Several stages of deformation have been recognized by different writers (Arndt and Wood, 1960; Nickelsen, 1979; see Wood and others, 1969, for a detailed discussion of anthracite structure in the Southern field, and see Faill, 1998, for a general summary). In general, the early stages of Alleghanian deformation resulted in the formation of ubiquitous coal cleats followed by layer-parallel shortening of strata above the basal décollement. Later stages of deformation apparently resulted in the development of multiple levels of décollement from which numerous imbricates splayed upward into overlying strata.

Arndt and Wood (1960) described five structural stages that ranged from broad folding and faulting to the development of recumbent folds and nappes. Nickelsen (1979) recognized seven stages of deformation in the Western Middle field. Wood and others (1969) placed a hypothetical décollement (Pottchunk fault) at or near the base of the upper member of the Mauch Chunk Formation and, among others, Arndt (1971), Wood and Arndt (1973), and Faill and Nickelsen (1999) interpreted faults exposed at the surface in the Southern field as splays (or tectonic ramps) from the underlying hypothetical Pottchunk fault. Wood and others (1986) noted that coal in the anthracite region was, in some places, structurally overthickened by flowage into the cores of synclines and, in other places, duplicated by faults. Furthermore, geologic structure locally affects the rank of the coal so that fixed-carbon content generally increases toward the core of tightly folded synclines and greatly deformed thrust faults (Wood and others, 1969).

Nevertheless, in spite of the complex geologic structures, there are relatively large areas where subhorizontal to 
moderately inclined coal beds can be accessed by the drill in the Southern field. For example, the detailed maps of Wood (1972) illustrated several areas in Schuylkill County, Pa., that may be suitable for CBM exploration.

\section{Coal as a Source Rock for Coalbed Methane}

\section{Gas-in-Place Data}

U.S. Bureau of Mines (USBM) gas-in-place data for the Pennsylvania Anthracite region (Diamond and others, 1986; Trevits and others, 1988) ranged from $6.4 \mathrm{CF} /$ ton in the Orchard coal bed to $691.2 \mathrm{CF} /$ ton in the Peach Mountain coal bed in the Southern field, which was the largest in-place value in the USBM database, nationwide (table 4). Of the 19 cores tested for gas-in-place values in the Northern field, the largest value obtained was $70.4 \mathrm{CF} /$ ton, for the Upper New County (No. 7) coal bed. Adsorption data (Langmuir isotherms) for Pennsylvania anthracite published by Lyons and others (2003) ranged from about $290 \mathrm{CF} /$ ton in the Buck Mountain coal bed to $900 \mathrm{CF} /$ ton in the Mammoth and Seven-foot beds.

\section{Thermal Maturity}

Thermal maturity (coal rank) of the coals in the Pennsylvania Anthracite region ranges from low-volatile bituminous coal to meta-anthracite (Hower and Gayer, 2002; Ruppert and others, this volume, chap. F.2). In general, vitrinite reflectance $\left(R_{\mathrm{o}}\right)$ values increase from 2 percent or less in the southwesternmost part of the anthracite fields to 6 percent or more in the northeastern part of the Southern field. $\mathrm{R}_{\mathrm{o}}$ values in the Northern field range from a little less to a little more than 4 percent (Hower and Gayer, 2002).

\section{Generation and Migration}

Thermal maturation commenced toward the end of the Paleozoic as the paleopeat deposits that became the anthracite coal fields were buried by sediments. Thermal maturity probably was reached during the latest Paleozoic, when the area was under the greatest sedimentary cover and, perhaps, beneath now-eroded Appalachian thrust sheets. In the Southern, Western Middle, and Eastern Middle fields, a possible temperature inversion is indicated where the older (lower) coal beds are of a lower rank than the younger (upper) coal beds (Edmunds and others, 1979; Levine, 1986; Levine and Davis, 1989). Explanations ranged from differential warming of the younger coal beds by means of hydrothermal fluids (Ruppert and others, this volume, chap. F.2) to the effects of a relatively warm, newly emplaced overthrust sheet (now eroded) (see Faill, 1998, for a summary). Wood and others (1969), however, noted that rank was closely related to local structural deformation, thus explaining the apparent temperature inversions more simply. Furthermore, Edmunds and others (1979)
Table 4. Gas-in-place data for the Northern and Southern fields of the Pennsylvania Anthracite region.

[Gas contents from Diamond and others (1986); measurements from two coal samples are followed by (2). Most coal beds are shown in figure $25 . \mathrm{CF} /$ ton, cubic feet per short ton]

\begin{tabular}{|c|c|}
\hline Coal bed & $\begin{array}{l}\text { Total gas } \\
\text { (CF/ton) }\end{array}$ \\
\hline \multicolumn{2}{|l|}{ Northern field } \\
\hline \multirow[t]{2}{*}{ 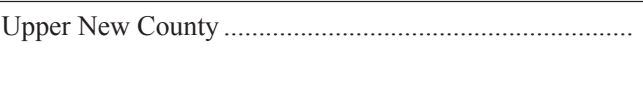 } & 70.4 \\
\hline & 54.4 \\
\hline \multirow[t]{6}{*}{ 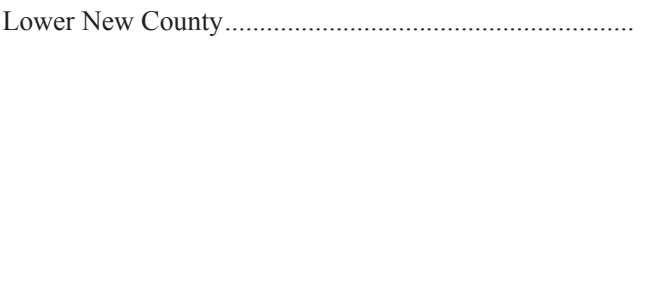 } & 48 \\
\hline & 41.6 \\
\hline & 32 \\
\hline & 28.8 \\
\hline & 25.6 \\
\hline & 16 \\
\hline \multirow[t]{5}{*}{ Big Bed (Pittston) . } & 64 \\
\hline & 54.4 \\
\hline & 44.8 \\
\hline & 32 \\
\hline & $28.8(2)$ \\
\hline \multirow[t]{3}{*}{ Clark (Ross) } & 16 (2) \\
\hline & 12.8 \\
\hline & $9.6(2)$ \\
\hline \multicolumn{2}{|l|}{ Southern field } \\
\hline \multirow[t]{3}{*}{ 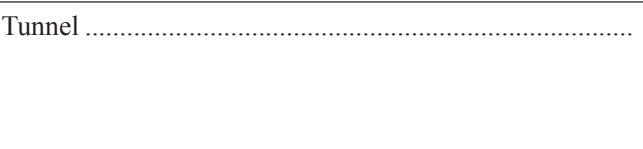 } & 585.6 \\
\hline & 448 \\
\hline & 403.2 \\
\hline \multirow[t]{2}{*}{ 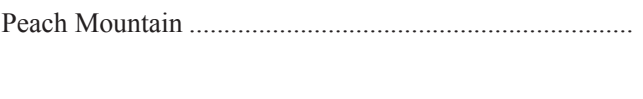 } & 691.2 \\
\hline & 601.6 \\
\hline \multirow[t]{2}{*}{ Orchard } & 28.8 \\
\hline & 6.4 \\
\hline Primrose ….............................. & 12.8 \\
\hline Seven Foot Leader & $396.8(2)$ \\
\hline
\end{tabular}

showed that the fixed-carbon content of Pennsylvanian coals increases from west to east across Pennsylvania and is, in general, greatest within the center of the anthracite fields, where the depth of burial would have been the greatest.

As with the coals in the other assessment units, methane generation probably began microbially during the first formation of peat and continued thermogenically as the paleopeat deposits were progressively buried during the Pennsylvanian (fig. 15). Progressive metamorphism thus has transformed the original paleopeat deposits from a complex mixture of organic chemicals to relatively pure carbon (anthracite) and methane. 


\section{Coal as a Reservoir for Coalbed Methane}

\author{
Porosity and Permeability
}

Fracture porosity is commonly well developed in anthracite and semianthracite coal beds. Anthracite in Pennsylvania commonly breaks with a conchoidal fracture. In some places, however, fractures may be prismatic and rectangular. In contrast, semianthracite commonly breaks with closely spaced rectangular and prismatic fractures and is rarely conchoidal (Wood and others, 1969).

\section{Coal-Bed Distribution}

Although anthracite is widely distributed throughout the synclinal coal fields in Pennsylvania, structural deformation may be so intense locally that it would inhibit the orderly development of CBM drilling units. Areas potentially most suitable for CBM development are in the relatively broad anticlinal and synclinal folds and perhaps in regions of gently to moderately inclined beds.

\section{Cumulative Coal Thickness}

The principal coal beds mined in the Southern, Eastern Middle, and Western Middle fields of Pennsylvania are the Lykens Valley coal zone (up to 11 coal beds) in the Pottsville Formation and the Buck Mountain, Seven-foot, Skidmore, Mammoth, Holmes, Primrose, and Orchard coal beds in the Llewellyn Formation (fig. 25) (Eggleston and Edmunds, 1981). Where these beds occur together, they are in a stratigraphic section that ranges from about 700 to $1,000 \mathrm{ft}$ in thickness, and their average cumulative thickness may total $75 \mathrm{ft}$ or more. The thickest coal bed is the Mammoth, which averages about $30 \mathrm{ft}$ in thickness (maximum about $65 \mathrm{ft}$ ). The others commonly range from 4 to $6 \mathrm{ft}$ in thickness. Where younger beds are present, including the Peach Mountain (No. 18) and Tunnel (No. 19), cumulative coal thickness may approach $100 \mathrm{ft}$ in a stratigraphic section that is 1,500 to $1,700 \mathrm{ft}$ thick (Wood and others, 1969; Eggleston and Edmunds, 1981).

\section{Seals}

In relatively unfaulted areas of the anthracite fields in Pennsylvania, seals consist of shales interbedded with the coals.

\section{Depth of Burial}

In Pennsylvania, the depth of burial of anthracite beds in geologic structures potentially suitable for CBM production ranges from several hundred feet to $2,000 \mathrm{ft}$ or more. In some places, the synclines may extend to depths of 5,000 ft or more (Eggleston and Edmunds, 1981).

\section{Water Production}

In Pennsylvania, the amount of interstitial water in the anthracite beds is unknown.

\section{Assessment Results}

Although the Pennsylvania Anthracite part of the Appalachian Anthracite and Semi-Anthracite Assessment Unit was defined in the 2002 USGS National Oil and Gas Assessment, its CBM resources have not been quantitatively assessed.

\section{Appalachian Anthracite and Semi-Anthracite Assessment Unit: Virginia Semi-Anthracite District}

\section{Introduction}

The coal-bearing strata of the Valley coal fields of Virginia and West Virginia are of Mississippian age and extend discontinuously within the folded and faulted strata of the Appalachian Valley and Ridge Province from Morgan and Berkeley Counties, W. Va., on the north through Rockingham and Augusta Counties, Va., to Wythe, Bland, Smyth, and Washington Counties, Va., on the south. Campbell and others (1925) divided these Valley coal fields into several groups based on their relative importance: (1) the fields of Montgomery and Pulaski Counties, Va.; (2) the fields of Wythe County, Va.; (3) the fields of Morgan and Berkeley Counties, W. Va.; (4) the fields of Bland and Smyth Counties, Va.; (5) the fields of Roanoke and Botetourt Counties, Va.; (6) the fields of Augusta and Rockingham Counties, Va.; and (7) scattered fields of little or no economic importance. Historical prospecting and mining of coal beds have occurred to some extent in many of these areas (Campbell and others, 1925). Only the fields of Montgomery and Pulaski Counties, Va., are considered herein (fig. 26). These fields make up the Virginia semianthracite district, which is a small part of the Valley coal fields.

The Virginia semianthracite district part of the Appalachian Anthracite and Semi-Anthracite Assessment Unit is shown in figure 26 . The assessment unit was defined in the 2002 USGS National Oil and Gas Assessment, but its CBM resources were not quantitatively assessed in that study.

In 1983, the Virginia Division of Mineral Resources evaluated the CBM potential of the coal fields in Montgomery County, Va. (fig. 27) (Stanley and Schultz, 1983). In this area, Mississippian coal beds are exposed within a structural window (fenster) through the Pulaski thrust sheet and along the western margin of the thrust sheet (fig. 26). Of the three coreholes drilled, two penetrated coal, which was desorbed using the method described by Diamond and Levine (1981). 


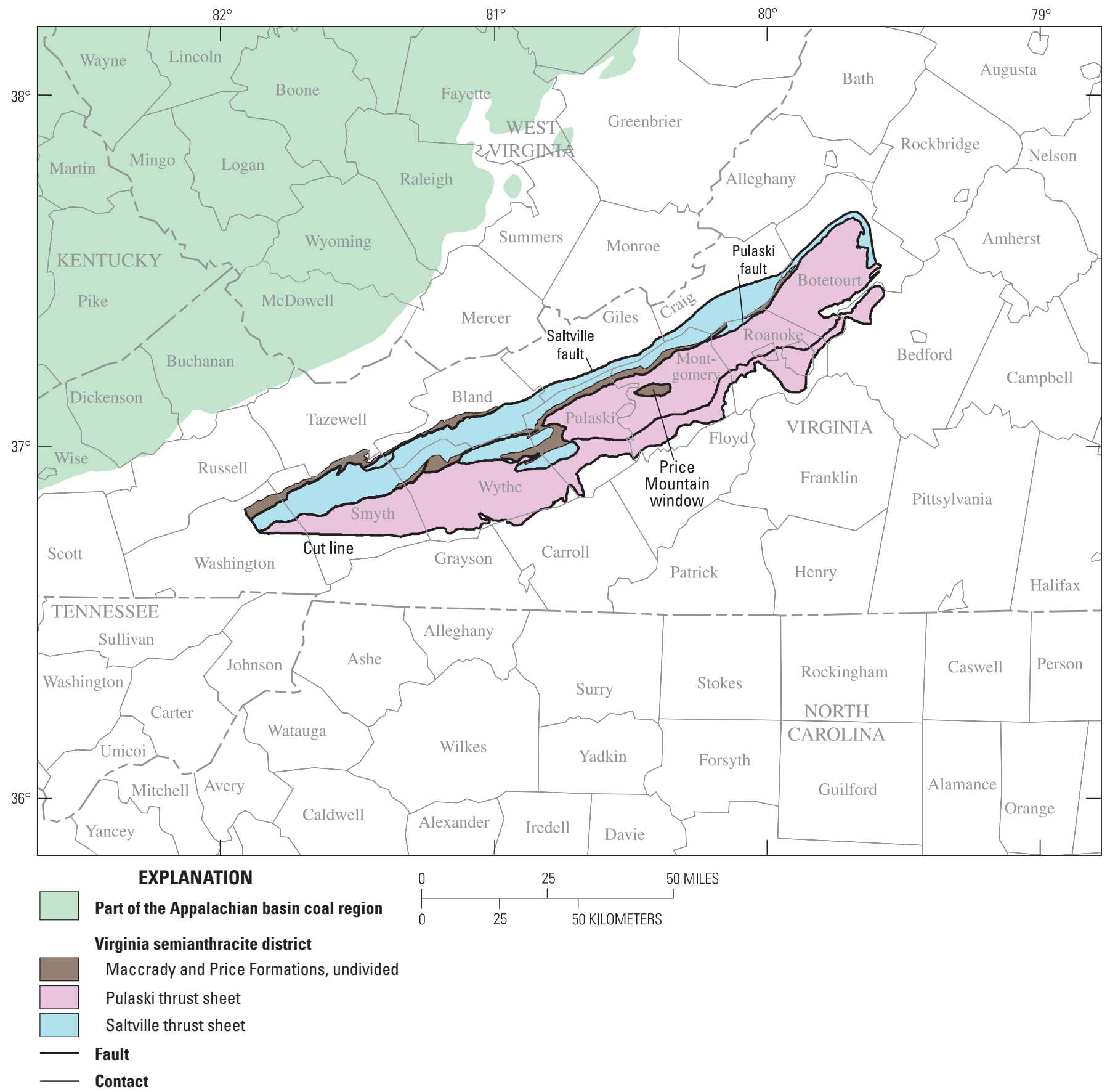

Figure 26. Map showing location and generalized geology of the Virginia semianthracite district, which is within the Appalachian Anthracite and Semi-Anthracite Assessment Unit; see figure 1. Coal beds of Mississippian age are exposed along the footwalls and in fensters (windows) through major Appalachian thrust sheets. Extent of thrust sheets from Virginia Division of Mineral Resources (1993).

\section{Stratigraphy}

\section{Cambrian Formations of the Pulaski Thrust Sheet}

In the coal-bearing area of Montgomery and Pulaski Counties, Va., the stratigraphic units may be divided into two general groupings: the older rocks of the Pulaski thrust sheet and the younger rocks of the footwall in the Saltville thrust sheet (table 5) (Bartholomew and Lowry, 1979). Rocks of the Pulaski thrust sheet include calcareous and phyllitic mudstones and argillaceous dolomites and limestones of the Rome Formation (Early Cambrian) and the Elbrook Formation (Middle Cambrian). The combined thickness of these units, now greatly deformed on the thrust sheet, may range from $2,300 \mathrm{ft}$ to nearly $3,000 \mathrm{ft}$. An unusually thick tectonic breccia 
(tens to hundreds of feet thick), the Max Meadows breccia (Schultz, 1986), is widely exposed on the Pulaski thrust sheet. The breccia occurs primarily in the upper part of the Rome Formation and the lower part of the Elbrook Formation. It consists generally of dolomite and mudstone clasts that are in a matrix of crushed dolomite or sheared phyllite (Stanley and Schultz, 1983; Schultz, 1986).

\section{Mississippian Formations of the Footwall}

Footwall strata range in age from Cambrian to Mississippian (table 5) and are exposed on the Saltville thrust sheet along the western edge of the Pulaski thrust sheet and in several anticlinal windows (fensters) that have been eroded through the Pulaski thrust sheet. Strata of Mississippian age, which include the Price and Maccrady Formations, are exposed within the Price Mountain window and in the footwall along the trace of the Pulaski fault, which bounds the Pulaski thrust sheet (fig. 27).

The Maccrady Formation is at the top of the section in the Virginia semianthracite district and consists of two members. The upper member is $180 \mathrm{ft}$ thick and consists of interbedded mudstones, siltstones, conglomeratic sandstones, and quartz-pebble conglomerates. The lower member is about $1,150 \mathrm{ft}$ thick and consists of grayish-red and greenish-gray mudstones, a few gray to black mudstones, and massive to crossbedded sandstones. The contact of the Maccrady with the underlying Price Formation is gradational and is placed where the grayish-red siltstones of the Maccrady give way to the gray siltstones and sandstones of the Price (Stanley and Schultz, 1983).

In general, the Price Formation (Early Mississippian) represents a westward-prograding delta and shoreline complex related to the Acadian orogeny (Kreisa and Bambach, 1973). The Price Formation consists of two parts: an upper coal-bearing part and a lower part that includes the basal Cloyd Conglomerate Member (Stanley and Schultz, 1983). The contact between the two parts is placed at the top of the first sandstone below coal-bearing mudstones.

The coal-bearing upper part is about $900 \mathrm{ft}$ thick. It consists of grayish-red to greenish-gray mudstones, gray to black mudstones, quartzose sandstones, and coal. The mined coal beds, the Merrimac and Langhorne, occur in the lower part of the upper member and range in thickness from 5 to $12 \mathrm{ft}$ and from 1 to $3 \mathrm{ft}$, respectively (Campbell and others, 1925; Stanley and Schultz, 1983). Kreisa and Bambach (1973) recognized three lithofacies within the upper part: (1) distributary channel sandstones, (2) delta-plain sandstone and shale, and (3) coal and carbonaceous shales that were deposited in mires. In places, the channel sandstones contain plant fossils and some burrows; plant fossils are commonly associated with both the delta-plain deposits and carbonaceous shale and coal.

The marine lower part is about $1,500 \mathrm{ft}$ thick. It consists of shale, siltstone, sandstone, and quartz-pebble conglomerate, with some bioturbated, fossiliferous beds of sandy shale.
Kreisa and Bambach (1973) recognized five lithofacies within the lower part: (1) fossiliferous marine shales, (2) interbedded prodelta-slope sandstones with sole markings, (3) massively bedded bar and barrier deposits of quartz arenites and quartzpebble conglomerates (Cloyd Conglomerate Member), (4) barred bay deposits of fossiliferous sandstones and mudstones, and (5) washover deposits of sandy conglomerates.

The Cloyd Conglomerate Member, which is in the basal bed in the lower part, is a conspicuous marker bed that consists of white sandstone and quartz-pebble conglomerate and that may contain marine fossils and comminuted plant debris. In places, the Cloyd is as thick as $20 \mathrm{ft}$ (Campbell and others, 1925).

\section{Geologic Structure}

The principal geologic structure of the Virginia semianthracite district is the Pulaski thrust sheet, which consists of complexly folded and faulted rocks of the Rome and Elbrook Formations. This fault carries deformed and brecciated Cambrian formations westward to where they overlie Mississippian-age strata within the underlying Saltville thrust sheet. In places, the Pulaski thrust sheet, which ranges up to about 5,000 ft in thickness, contains several structural windows that expose strata that range in age from Cambrian to Mississippian. The windows are of two general types: (1) those that contain horses of severely deformed Cambrian to Devonian strata (Schultz, 1988) and (2) the Price Mountain window, which exposes the relatively undeformed strata of the Mississippian footwall as well as a complexly deformed horse of older rocks. Schultz (1988) hypothesized that 12 horses of greatly deformed Cambrian to Devonian strata exposed along the trace of the Pulaski fault and in the windows eroded through the eastern part of the Pulaski thrust sheet were rootless and overlay Mississippian-age strata at depth. If Schultz (1988, fig. 3) is correct, Mississippian strata and their contained coal beds may extend buried in the footwall of the Pulaski thrust sheet eastward beneath the leading edge of the Blue Ridge thrust sheet.

\section{Coal as a Source Rock for Coalbed Methane}

\section{Gas-in-Place Data}

Three State coreholes and six commercial CBM tests were drilled in and near the Pulaski thrust sheet (fig. 27, tables 6, 7, 8, and 9). The three State coreholes were drilled in Montgomery County by the Virginia Division of Mineral Resources (VDMR) in 1982 (Stanley and Schultz, 1983). The six commercial tests were drilled in Pulaski County by Mr. John Goldsmith of Radford, Va., for a joint venture among the Toms Creek Energy Co., New River Gas Co., Valley Basin Gas Associates, and Amoco (J.L. Coleman, USGS, written commun., 2004). 


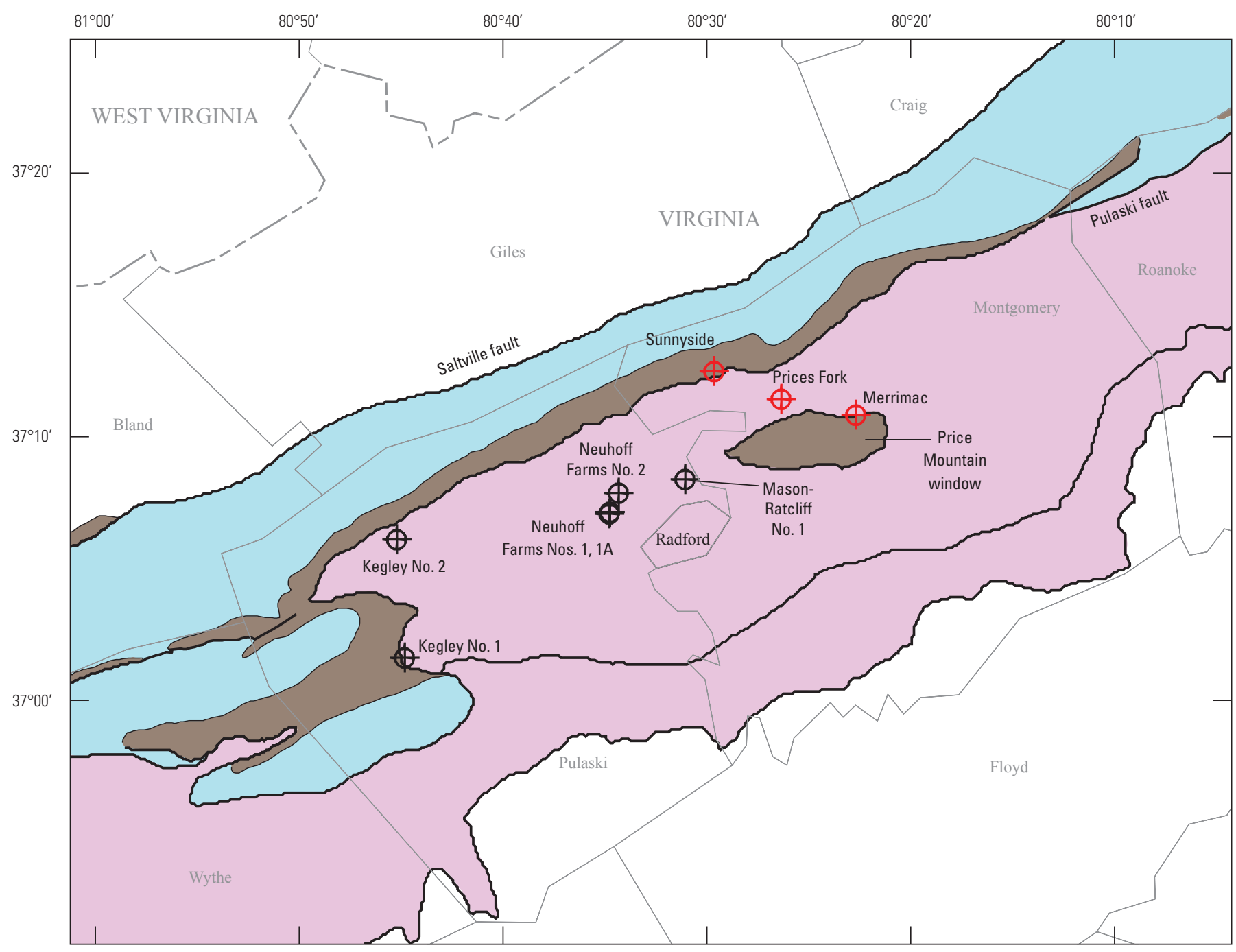

\section{EXPLANATION}

Virginia semianthracite district

Maccrady and Price Formations, undivided

Pulaski thrust sheet

Saltville thrust sheet

\section{- Fault \\ Contact \\ Đ Commercial CBM test corehole \\ Ф VDMR corehole}

Figure 27. Map of the central part of the Virginia semianthracite district, showing locations of Virginia Division of Mineral Resources (VDMR) coreholes and commercial coalbed-methane (CBM) test coreholes near Radford, Va. Map enlarged from figure 26. Coordinates and other data for coreholes and tests are in tables $6,7,8$, and 9. 
Table 5. Stratigraphic nomenclature of the Price Mountain area in the Virginia semianthracite district.

[Nomenclature adapted from Stanley and Schultz (1983). The Virginia semianthracite district is shown in figure 26]

\begin{tabular}{|c|c|c|c|}
\hline \multirow[b]{2}{*}{ System } & \multirow[b]{2}{*}{ Formation } & \multicolumn{2}{|c|}{ Thickness (feet) } \\
\hline & & $\begin{array}{c}\text { Saltville } \\
\text { thrust } \\
\text { sheet }\end{array}$ & $\begin{array}{c}\text { Pulaski } \\
\text { thrust } \\
\text { sheet }\end{array}$ \\
\hline \multirow[t]{5}{*}{ Mississippian } & Maccrady Formation & 1,605 & -- \\
\hline & Price Formation & 975 & -- \\
\hline & Merrimac coal & -- & -- \\
\hline & Langhorne coal & -- & -- \\
\hline & $\begin{array}{l}\text { Cloyd Conglomerate } \\
\text { Member }\end{array}$ & -- & -- \\
\hline \multirow[t]{6}{*}{ Devonian } & Chemung Formation & 698 & -- \\
\hline & Brallier Formation & 2,699 & -- \\
\hline & Millboro Shale & 850 & -- \\
\hline & Needmore Shale & 30 & -- \\
\hline & Huntersville Chert & 30 & -- \\
\hline & Rocky Gap Sandstone & 40 & -- \\
\hline \multirow[t]{3}{*}{ Silurian } & Keefer Sandstone & 140 & -- \\
\hline & Rose Hill Formation & 127 & -- \\
\hline & Tuscarora Sandstone & 100 & -- \\
\hline \multirow[t]{4}{*}{ Ordovician } & Juniata Formation & 165 & -- \\
\hline & Martinsburg Formation & 980 & -- \\
\hline & Moccasin Formation & 55 & -- \\
\hline & $\begin{array}{l}\text { Middle Ordovician rocks } \\
\quad \text { (undivided) }\end{array}$ & 529 & -- \\
\hline \multirow{2}{*}{$\begin{array}{l}\text { Ordovician and } \\
\text { Cambrian }\end{array}$} & Knox Group & 2,563 & -- \\
\hline & Conococheague Limestone & -- & 1,800 \\
\hline \multirow[t]{4}{*}{ Cambrian } & Nolichucky Shale & 56 & -- \\
\hline & Honaker Dolomite & 826 & -- \\
\hline & Elbrook Formation $\left(\right.$ breccia $\left.^{1}\right)$ & -- & 1,800 \\
\hline & Rome Formation & -- & $600+$ \\
\hline
\end{tabular}

${ }^{1}$ The Max Meadows breccia (Schultz, 1986) is widely exposed on the Pulaski thrust sheet. The breccia occurs primarily in the upper part of the Rome Formation and the lower part of the Elbrook Formation.
Merrimac coals from $1,110.05$ to $1,120.8 \mathrm{ft}$ and the Langhorne coals from $1,134.22$ to $1,139.18 \mathrm{ft}$ and $1,194.9$ to $1,198.6$ ft. A third corehole (VDMR well W-6535, Merrimac test) was drilled near the northwestern side of the Price Mountain window; it went through the Pulaski thrust sheet at about 104 $\mathrm{ft}$ and penetrated the Merrimac coal in three thin beds between 1,403.5 and 1,411.9 ft. Seven thin coals of the Langhorne interval were penetrated between 1,420 and 1,481 ft (Stanley and Schultz, 1983).

Table 7 summarizes the desorption data from the Merrimac and Langhorne coals in the Sunnyside (W-6534) and Merrimac (W-6535) wells, which yield a weighted average of 202.2 CF/ton and 230.6 CF/ton, respectively. An economic analysis conducted by Gruy Petroleum Technology Incorporated (Stanley and Schultz, 1983) assumed the original gas-in-place to be 3,220 MCF/acre, which was consistent with these desorption values. They concluded, however, that the coal thicknesses measured in the two cores were not great enough to supply an economic amount of gas relative to the costs of exploration and development and suggested that twice that amount of coal may be needed for the successful development of a CBM field. Although Campbell and others (1925) reported coal thicknesses as great as $22 \mathrm{ft}$ in Pulaski County coal fields, thicknesses this great appear to be exceptional and not widespread across the region of Pulaski and Montgomery Counties.

Of the six commercial wells drilled for CBM in the mid1980s (tables 8 and 9), four penetrated coal of considerable thickness and gas content; coals in two of these wells were hydraulically fractured and tested. Although the gas content of coals in two of the wells ranged from 508 to $664 \mathrm{CF} /$ ton (table 9), the wells yielded non-economic flows of gas, most likely because of very low permeability (J.L. Coleman, USGS, written commun., 2004).

\section{Thermal Maturity}

Thermal maturity of Mississippian-age coal from surface locations in the Valley and Ridge Province is indicated by vitrinite reflectance $\left(\mathrm{R}_{\mathrm{o}}\right)$ values that range from $1.41 \% \mathrm{R}_{\mathrm{o}}$ (medium-volatile bituminous) in Wythe County, Va., to $2 \% \mathrm{R}_{\mathrm{o}}$ (semianthracite) in Montgomery County, Va. (unpub. data courtesy of Leslie Ruppert, USGS, 2002). In Pulaski County, the vitrinite reflectance values for coals in the New River Gas, Neuhoff Farms No. 1 well were a little greater and ranged from 2.5 to $2.7 \% \mathrm{R}_{\mathrm{o}}$ (table 9) (J.L. Coleman, USGS, written commun., 2004).

\section{Generation and Migration}

Methane was generated by microbial activity when the Mississippian peat deposits first formed. Although much of this swamp gas was lost to the atmosphere, microbial generation of methane continued at depth until the ambient temperatures became too great. When the coal beds were buried 
Table 6. Locations of three coreholes drilled in the Virginia semianthracite district in Montgomery County by the Virginia Division of Mineral Resources in 1982 in a search for coalbed methane.

[Data from Stanley and Schultz (1983). Corehole locations are plotted in figure 27. Desorption data for two coreholes are in table 7; no desorption data were available for the Prices Fork corehole, which failed to penetrate coal. ft, feet]

\begin{tabular}{|c|c|c|c|c|c|c|}
\hline Number & Name & Quadrangle & Longitude & Latitude & $\begin{array}{l}\text { Elevation } \\
\text { (ft) }\end{array}$ & $\begin{array}{l}\text { Total depth } \\
\text { (ft) }\end{array}$ \\
\hline $\mathrm{W}-6533 \ldots \ldots \ldots \ldots \ldots$ & Prices Fork ................ & 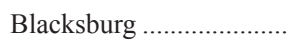 & -80.48861111 & 37.21222222 & $2,037.0$ & $1,773.5$ \\
\hline $\mathrm{W}-6534 \ldots \ldots \ldots \ldots \ldots$ & Sunnyside................. & Radford North ..................... & -80.54166667 & 37.23000000 & $2,015.0$ & $1,672.0$ \\
\hline W-6535 .................. & Merrimac ................ & Blacksburg .................... & -80.42972222 & 37.20222222 & $2,090.0$ & $1,674.0$ \\
\hline
\end{tabular}

Table 7. Desorption data from the Merrimac and Langhorne coals in two coreholes drilled in the Virginia semianthracite district in Montgomery County.

[Desorption data are from Stanley and Schultz (1983). Coreholes were drilled by the Virginia Division of Mineral Resources (VDMR). Corehole locations are in table 6 and figure 27. Abbreviations: $\mathrm{CF} / \mathrm{ton}$, cubic feet per short ton; $\mathrm{cm}^{3}$, cubic centimeters; $\mathrm{cm}^{3} / \mathrm{g}$, cubic centimeters per gram; ft, feet; g, grams]

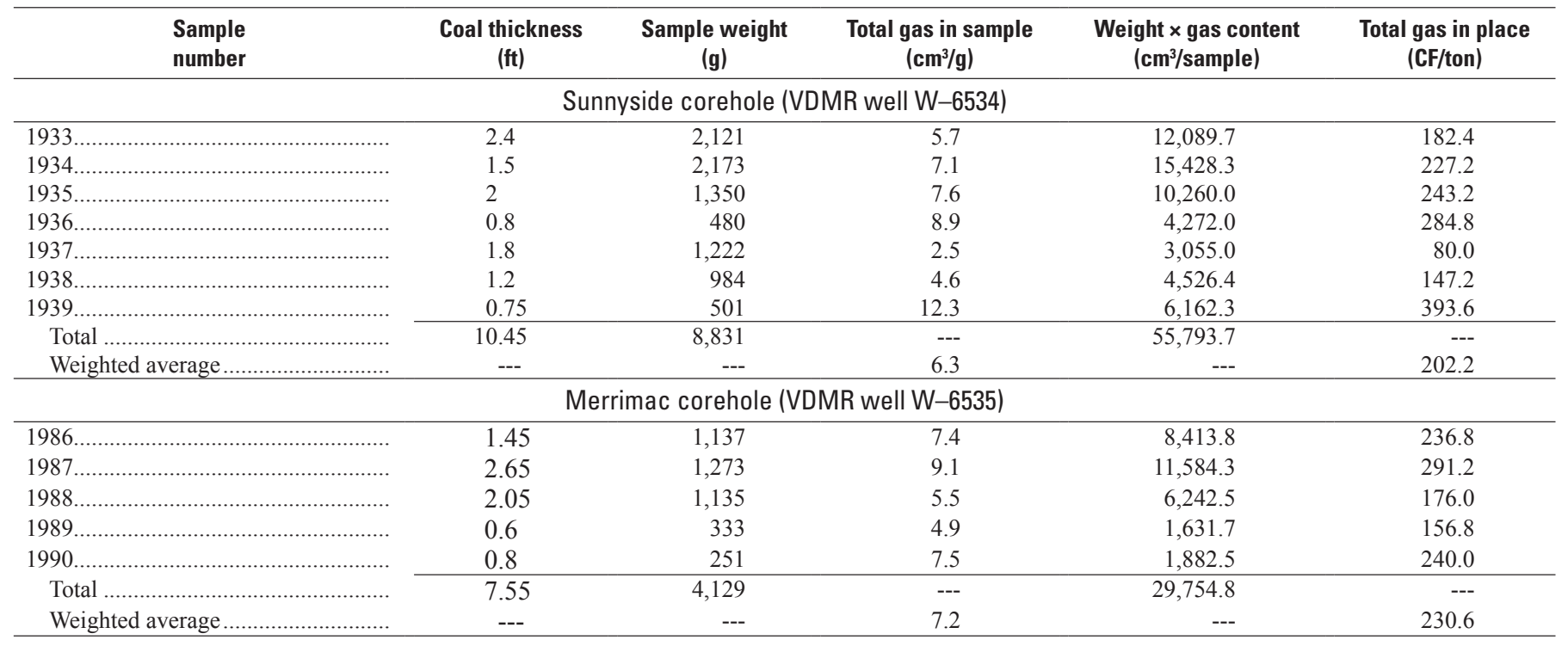

sufficiently deeply by overlying sediments, temperatures became high enough to support the formation of thermogenic gas, probably sometime in the Late Mississippian and Early Pennsylvanian (fig. 15). Alleghanian folding and faulting deformed the coal beds and their enclosing strata. Methane may well have been lost from the coal beds in areas of intense deformation. Where deformation is moderate, so that seals have not been broken, increased fracture porosity may result in more rapid desorption of the gas into the fracture network and thence into the wellbore once the coal beds are drilled.

\section{Coal as a Reservoir for Coalbed Methane}

\section{Porosity and Permeability}

In general, porosity and permeability are enhanced in areas of moderate deformation and fracturing. Where deformation is intense, however, seals may be broken and CBM lost. Following commercial exploration in Pulaski County, Va., in the mid-1980s, Amoco discontinued exploration in the area. Company scientists concluded that the relatively high thermal maturity of the coal, combined with bedding-parallel faulting in the coal beds, resulted in the very low permeability observed (J.L. Coleman, USGS, written commun., 2004).

\section{Coal-Bed Distribution}

In Pulaski and Montgomery Counties, Va., the coalbearing strata of the Price Formation are exposed along the trace of the Pulaski fault and in the Price Mountain window. The coal-bearing zone may extend at depth from its exposure eastward beneath the Pulaski thrust sheet to the leading edge of the Blue Ridge thrust sheet (Schultz, 1988). 

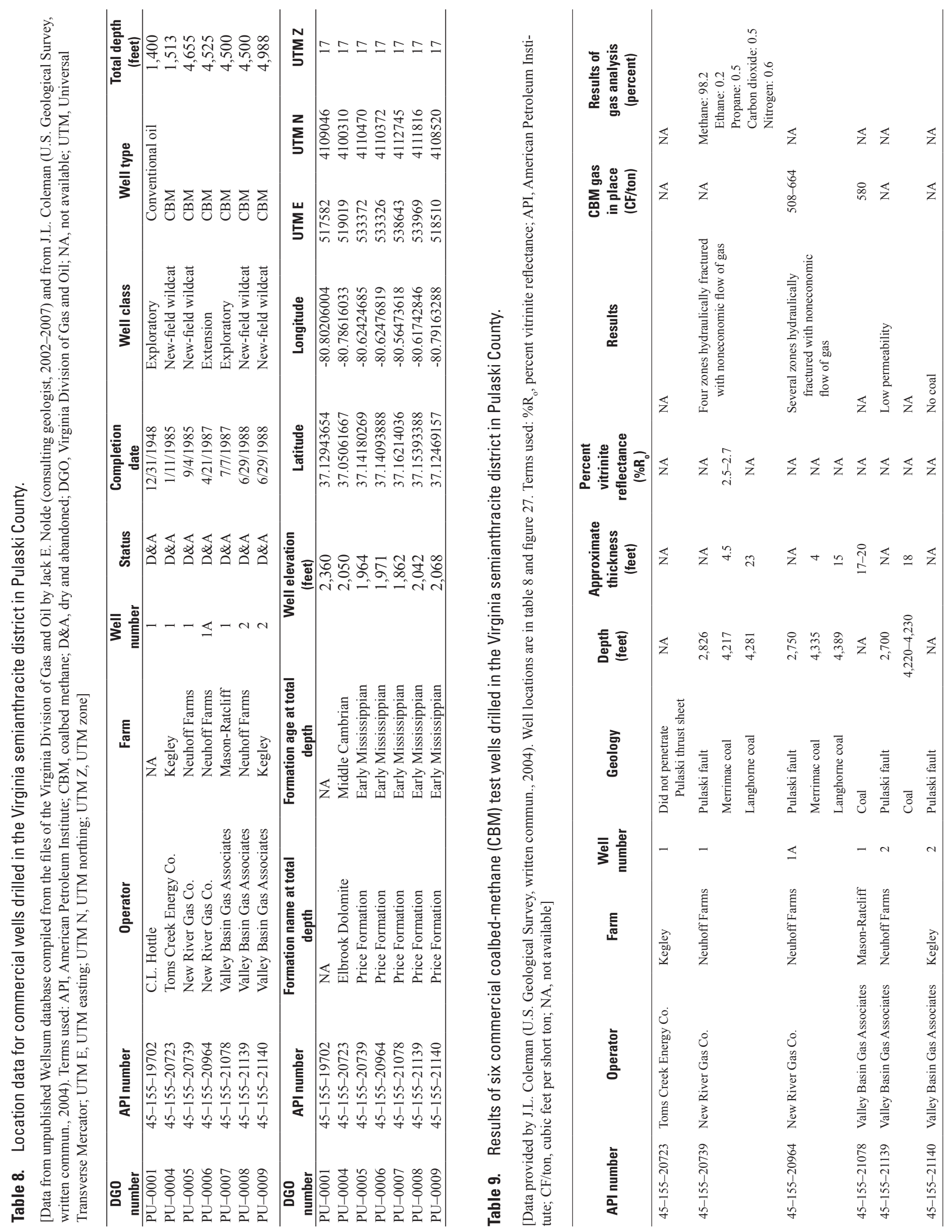


\section{Cumulative Coal Thickness}

Cumulative coal thickness may range from about 6 or $7 \mathrm{ft}$ to $22 \mathrm{ft}$ or more in the Virginia semianthracite district (Campbell and others, 1925).

\section{Seals}

The coal beds in Pulaski and Montgomery Counties occur within black, carbonaceous mudstones, which are interbedded with subordinate amounts of sandstone and siltstone. The finegrained rocks may serve as effective seals for CBM (Stanley and Schultz, 1983).

\section{Depth of Burial}

Coal beds of the Price Formation may extend eastward from their cropline in the footwall of the Pulaski fault (fig. 26), beneath the Pulaski thrust sheet to depths of 5,000 ft or more.

\section{Water Production}

The amount of interstitial water in the semianthracite beds in Pulaski and Montgomery Counties, Va., is unknown.

\section{Assessment Results}

Although the Virginia semianthracite district in the Appalachian Anthracite and Semi-Anthracite Assessment Unit was defined in the 2002 USGS National Oil and Gas Assessment, its CBM resources have not been quantitatively assessed. The Appalachian Anthracite and Semi-Anthracite AU should be regarded as hypothetical until there is a successful demonstration of a commercially active petroleum system.

\section{References Cited}

Alabama State Oil and Gas Board, 2002, Coalbed methane resources of Alabama: Tuscaloosa, Ala., Alabama State Oil and Gas Board Web site at http://www.ogb.state.al.us/. (Accessed in 2002; production data are updated monthly at the new Web site, which was accessed Aug. 23, 2007, at http://www.ogb.state.al.us/ogb/month_prod_sum.html.)

Alabama State Oil and Gas Board, 2004, Coalbed methane resources of Alabama: Tuscaloosa, Ala., Alabama State Oil and Gas Board Web site at http://www.ogb.state.al.us/. (Accessed in 2004; see citation above.)

American Society for Testing and Materials (ASTM), 1996, D3180-89, Standard practice for calculating coal and coke analyses from as-determined to different bases: Annual
Book of ASTM Standards, v. 05.06, Gaseous fuels; Coal and coke, p. 314-316.

Arkle, Thomas, Jr., Beissell, D.R., Larese, R.E., Nuhfer, E.B., Patchen, D.G., Smosna, R.A., Gillepsie, W.H., Lund, Richard, Norton, C.W., and Pfefferkorn, H.W., 1979, The Mississippian and Pennsylvanian (Carboniferous) Systems in the United States-West Virginia and Maryland: U.S. Geological Survey Professional Paper 1110-D, p. D1-D35.

Arndt, H.H., 1971, Geologic map of the Ashland quadrangle, Columbia and Schuylkill Counties, Pennsylvania: U.S. Geological Survey Geologic Quadrangle Map GQ-918, scale $1: 24,000$.

Arndt, H.H., Averitt, Paul, Dowd, James, Frendzel, D.J., and Gallo, P.A., 1968, Coal, in U.S. Geological Survey and U.S. Bureau of Mines, Mineral resources of the Appalachian region: U.S. Geological Survey Professional Paper 580, p. $102-133$.

Arndt, H.H., and Wood, G.H., Jr., 1960, Late Paleozoic orogeny in eastern Pennsylvania consists of five progressive stages, in Short papers in the geological sciences, chap. B of Geological Survey research 1960: U.S. Geological Survey Professional Paper 400, p. B182-B184.

Attanasi, E.D., 1998, Relative importance of physical and economic factors in Appalachian coalbed gas assessment: International Journal of Coal Geology, v. 38, no. 1-2, p. 47-59.

Avary, K.L., 2004, Coal-bed methane wells reported to WVGES: Morgantown, W. Va., West Virginia Geological and Economic Survey table available online at http:/ims. wvgs.wvnet.edu/datastat/cbm/dtcm 90 s1.htm. (No longer available; data available by querying database at http:// www.wvgs.wvnet.edu/www/datastat/cbm/cbm_results.asp, accessed June 30, 2014.)

Bartholomew, M.J., and Lowry, W.D., 1979, Geology of the Blacksburg quadrangle, Virginia: Virginia Division of Mineral Resources Publication 14, scale 1:24,000.

Berg, T.M., Edmunds, W.E., Geyer, A.R., Glover, A.D., Hoskins, D.M., MacLachlan, D.B., Root, S.I., Sevon, W.D., and Socolow, A.A., comps., 1980, Geologic map of Pennsylvania: Harrisburg, Pa., Pennsylvania Bureau of Topographic and Geologic Survey, 3 sheets, scale 1:250,000.

Blake, B.M., Jr., Keiser, A.F., and Rice, C.L., 1994, Revised stratigraphy and nomenclature for the Middle Pennsylvanian Kanawha Formation in southwestern West Virginia, in Rice, C.L., ed., Elements of Pennsylvanian stratigraphy, central Appalachian basin: Geological Society of America Special Paper 294, p. 41-53.

Bruner, K.R., Oldham, A.V., Repine, T.E., Markowski, A.K., and Harper, J.A., 1995, Geological aspects of coalbed methane in the northern Appalachian coal basin, southwestern 
Pennsylvania and north-central West Virginia: Gas Research Institute Topical Report GRI-95/0221, 72 p.

Bruner, K.R., Oldham, A.V., Repine, T.E., Markowski, A.K., and Harper, J.A., 1998, Geological aspects of coalbed methane in the northern Appalachian coal basin, southwestern Pennsylvania and north-central West Virginia: Pennsylvania Geological Survey Open-File Report 98-13, 72 p. (Reprinted from Bruner and others, 1995, Gas Research Institute (Chicago) Topical Report GRI-95/0221.)

Campbell, M.R., and others, 1925, The Valley coal fields of Virginia: Virginia Geological Survey Bulletin 25, 322 p., 27 pls., 1 map in pocket.

Cardwell, D.H., Erwin, R.B., and Woodward, H.P., comps., 1968, Geologic map of West Virginia: Morgantown, W. Va., West Virginia Geological and Economic Survey, 2 sheets, scale 1:250,000.

Chesnut, D.R., Jr., 1992, Stratigraphic and structural framework of Carboniferous rocks in the central Appalachian basin in Kentucky: Kentucky Geological Survey, ser. 11, Bulletin 3, 42 p., 8 maps in pocket.

Collins, H.R., 1979, The Mississippian and Pennsylvanian (Carboniferous) Systems in the United States-Ohio: U.S. Geological Survey Professional Paper 1110-E, p. E1-E26.

Diamond, W.P., and Levine, J.R., 1981, Direct method determination of the gas content of coal; Procedures and results: U.S. Bureau of Mines Report of Investigations 8515, 36 p. (Also available online at http://www.cdc.gov/niosh/mining/ UserFiles/works/pdfs/ri8515.pdf.)

Diamond, W.P., LaScola, J.C., and Hyman, D.M., 1986, Results of direct-method determination of the gas content of U.S. coalbeds: U.S. Bureau of Mines Information Circular 9067, 95 p. (Also available online at http:/www.cdc.gov/ niosh/mining/UserFiles/works/pdfs/ic9067.pdf.) (Accessed April 18, 2007.)

Dolton, G.L., Varnes, K.L., Gautier, D.L., and Barnett, D.L., 1995, Oil and gas resources assessment areas, 1995, lower 48 States: U.S. Geological Survey Open-File Report 95-75-I, 1 sheet, scale 1:5,000,000.

Drahovzal, J.A., Eble, C.F., and Nuttall, B.C., 2002, Coalbed methane potential of eastern Kentucky: Oklahoma City, Okla., Interstate Oil \& Gas Compact Commission Web site at http://www.iogcc.state.ok.us/ISSUES/CSNG/csng.htm. (Accessed in 2004; Web site not available in 2007 per J.A. Drahovzal.)

Edmunds, W.E., 1999, Bituminous coal, chap. 37 of Shultz, C.H., ed., The geology of Pennsylvania: Pennsylvania Geological Survey Special Publication 1, p. 471-481.
Edmunds, W.E., Berg, T.M., Sevon, W.D., Piotrowski, R.C., Heyman, Louis, and Rickard, L.V., 1979, The Mississippian and Pennsylvanian (Carboniferous) Systems in the United States-Pennsylvania and New York: U.S. Geological Survey Professional Paper 1110-B, p. B1-B33.

Edmunds, W.E., Skema, V.W., and Flint, N.K. 1999, Pennsylvanian, chap. 10 of Shultz, C.H., ed., The geology of Pennsylvania: Pennsylvania Geological Survey Special Publication 1, p. 148-169.

Eggleston, J.R., and Edmunds, W.E., 1981, Field guide to the anthracite coal basins of eastern Pennsylvania: Atlantic Margin Energy Symposium (1981, Atlantic City, N.J.) Field Guide, 90 p.

Eggleston, J.R., Kehn, T.M., and Wood, G.H., Jr., 1999, Anthracite, chap. 36 of Shultz, C.H., ed., The geology of Pennsylvania: Pennsylvania Geological Survey Special Publication 1, p. 459-469.

Englund, K.J., 1979, The Mississippian and Pennsylvanian (Carboniferous) Systems in the United States-Virginia: U.S. Geological Survey Professional Paper 1110-C, p. C1-C21.

Englund, K.J., and Thomas, R.E., 1990, Late Paleozoic depositional trends in the central Appalachian basin, chap. F of Evolution of sedimentary basins - Appalachian basin: U.S. Geological Survey Bulletin 1839, p. F1-F19, 1 oversize section in pocket.

Englund, K.J., Windolph, J.F., Jr., and Thomas, R.E., 1986, Origin of thick, low-sulphur coal in the Lower Pennsylvanian Pocahontas Formation, Virginia and West Virginia, in Lyons, P.C., and Rice, C.L., eds., Paleoenvironmental and tectonic controls in coal-forming basins of the United States: Geological Society of America Special Paper 210, p. $49-61$.

Faill, R.T., 1998, A geologic history of the north-central Appalachians; Part 3, The Alleghany orogeny: American Journal of Science, v. 298, no. 2, p. 131-179.

Faill, R.T., and Nickelsen, R.P., 1999, Appalachian Mountain section of the Ridge and Valley province, chap. 19 of Shultz, C.H., ed., The geology of Pennsylvania: Pennsylvania Geological Survey Special Publication 1, p. 269-285.

Fenneman, N.M., 1938, Physiography of the Eastern United States: New York, McGraw-Hill Book Company, Inc., 714 p., 7 pls.

Ferm, J.C., 1974, Carboniferous environmental models in Eastern United States and their significance, in Briggs, Garrett, ed., Carboniferous of the Southeastern United States: Geological Society of America Special Paper 148, p. 79-95. 
Flint, N.K., 1965, Geology and mineral resources of southern Somerset County, Pennsylvania: Pennsylvania Geological Survey, 4th ser., County Report C56A, 267 p., 12 pls. in a box.

Frey, M.G., 1973, Influence of Salina salt on structure in New York-Pennsylvania part of Appalachian Plateau: American Association of Petroleum Geologists Bulletin, v. 57, no. 6, p. $1027-1037$.

Glover, A.D., and Bragonier, W.A., 1978, Geology and mineral resources of the Hazen, Falls Creek, Reynoldsville, and DuBois quadrangles, Clearfield and Jefferson Counties, Pennsylvania: Pennsylvania Bureau of Topographic and Geologic Survey, Topographic and Geologic Atlas of Pennsylvania, no. 64, $131 \mathrm{p}$.

Greb, S.F., and Chesnut, D.R., Jr., 1996, Lower and lower Middle Pennsylvanian fluvial to estuarine deposition, central Appalachian basin; Effects of eustacy, tectonics, and climate: Geological Society of America Bulletin, v. 108, no. 3, p. 303-317.

Hardeman, W.D., Miller, R.A., and Swingle, G.D., 1966, Geologic map of Tennessee: Nashville, Tennessee Division of Geology, 4 sheets, scale 1:250,000.

Harris, L.D., and Milici, R.C., 1977, Characteristics of thinskinned style of deformation in the southern Appalachians and potential hydrocarbon traps: U.S. Geological Survey Professional Paper 1018, 40 p.

Henika, W.S., 1994, Internal structure of the coal-bearing portion of the Cumberland overthrust block in southwestern Virginia and adjoining areas, in Geology and mineral resources of the southwest Virginia coalfield: Virginia Division of Mineral Resources Publication 131, p. 100-120.

Hower, J.C., and Gayer, R.A., 2002, Mechanisms of coal metamorphism; Case studies from Paleozoic coalfields: International Journal of Coal Geology, v. 50, p. 215-245.

Iannacchione, A.T., and Puglio, D.G., 1979, Geology of the Lower Kittanning coalbed and related mining and methane emission problems in Cambria County, Pa.: U.S. Bureau of Mines Report of Investigations 8354, 31 p. (Also available online at http://www.cdc.gov/niosh/mining/UserFiles/ works/pdfs/ri8354.pdf.)

Jillson, W.R., 1919, The Kendrick Shale-A new calcareous fossil horizon in the coal measures of eastern Kentucky: Kentucky Department of Geology and Forestry, ser. 5 [of Kentucky Geological Survey], Mineral and Forest Resources of Kentucky, v. 1, no. 2, p. 96-104.

Kentucky Division of Oil and Gas Conservation, 2004, Oil and gas production records: Frankfort, Ky., Kentucky Division of Oil and Gas Conservation Web site at http://dmm. ppr.ky.gov/OilandGas.htm. (Accessed in 2004, but no lon- ger available; data may be available by querying database at http://oilandgas.ky.gov/Pages/ProductionReports.aspx, accessed June 30, 2014.)

Kentucky Geological Survey, 2006, Maps and GIS; Various geologic coverages of the state [Kentucky]: Lexington, Ky., Kentucky Geological Survey Web site at http://www.uky. edu/KGS/gis/geology.htm.

Kreisa, R.D., and Bambach, R.K., 1973, Environments of deposition of the Price Formation (Lower Mississippian) in its type area, southwestern Virginia: American Journal of Science Cooper Volume, v. 273-A, p. 326-343.

Laughrey, C.D., and Baldassare, F.J., 1998, Geochemistry and origin of some natural gases in the Plateau province, central Appalachian basin, Pennsylvania and Ohio: American Association of Petroleum Geologists Bulletin, v. 82, no. 2, p. 317-335.

Levine, J.R., 1986, Deep burial of coal-bearing strata, anthracite region, Pennsylvania; Sedimentation or tectonics?: Geology, v. 14, no. 7, p. 577-580.

Levine, J.R., and Davis, Alan, 1989, The relationship of coal optical fabrics to Alleghanian tectonic deformation in the central Appalachian fold-and-thrust belt, Pennsylvania: Geological Society of America Bulletin, v. 101, no. 10, p. 1333-1347.

Lewis, R.T., 1999, Coalbed methane production of the Buck Knob anticline field, Wise County, Virginia [abs.]: American Association of Petroleum Geologists Bulletin, v. 83, no. 8, p. 1370.

Lyons, P.C., 1998, The central and northern Appalachian basin-A frontier region for coalbed methane development: International Journal of Coal Geology, v. 38, no. 1-2, p. $61-87$.

Lyons, P.C., Bustin, R.M., and Markowski, A.K., 2003, Coalbed methane potential (CBM-P) in main bituminous field (SW. PA) and the anthracite fields (E. PA), and CBM-P in MD, VA, MA, RI (U.S.A.) [abs.]: Program and abstracts for the twentieth annual meeting of The Society for Organic Petrology, 2003, ISSN 1060-7250, Washington, D.C., area, p. 72-74. (Abstract is also available online in U.S. Geological Survey Open-File Report 2004-1283 at http://pubs.usgs. gov/of/2004/1283/.)

Magoon, L.B., 1988, The petroleum system-A classification scheme for research, exploration, and resource assessment, in Magoon, L.B., ed., Petroleum systems of the United States: U.S. Geological Survey Bulletin 1870, p. 2-15.

Markowski, A.K., 1998, Coalbed methane resource potential and current prospects in Pennsylvania: International Journal of Coal Geology, v. 38, no. 1-2, p. 137-159. 
Markowski, A.K., 2000, Pennsylvania coalbed methane wells spreadsheet: Pennsylvania Geological Survey, 4th ser., Open-File Report 00-01, 1 diskette (3.5 inches), 580 p. (legal size). (Also available online at http://www.denr.state. pa.us/topogeo/publications/pgspub/openfile/index.htm; scroll down to OF 00-01 to access zipped file; accessed May 21, 2014.)

Markowski, A.K., 2001, Reconnaissance of the coal-bed methane resources in Pennsylvania: Pennsylvania Bureau of Topographic and Geologic Survey Mineral Resource Report 95, $134 \mathrm{p}$.

Martino, R.L., 1994, Facies analysis of Middle Pennsylvanian marine units, southern West Virginia, in Rice, C.L., ed., Elements of Pennsylvanian stratigraphy, central Appalachian basin: Geological Society of America Special Paper 294, p. 69-86.

McColloch, G.H., Jr., 1995, West Virginia, in Keystone Coal Industry Manual: Chicago, Ill., p. G178-G188.

Milici, R.C., 2004, Assessment of Appalachian basin oil and gas resources; Carboniferous Coal-Bed Gas Total Petroleum System: U.S. Geological Survey Open-File Report 20041272,98 p., available only online at http://pubs.usgs.gov/ of/2004/1272/. (Superseded by USGS Professional Paper $1708-$ G.1, which is this report.)

Milici, R.C., Briggs, Garrett, Knox, L.M., Sitterly, P.D., and Statler, A.T., 1979, The Mississippian and Pennsylvanian (Carboniferous) Systems in the United States-Tennessee: U.S. Geological Survey Professional Paper 1110-G, p. G1-G38.

Milici, R.C., Freeman, P.A., and Bragg, L.J., 2001, Chapter $\mathrm{H}-\mathrm{A}$ digital resource model of the Lower Pennsylvanian Pocahontas No. 3 coal bed, Pottsville Group, central Appalachian basin coal region, in Northern and Central Appalachian Basin Coal Regions Assessment Team, 2000 resource assessment of selected coal beds and zones in the northern and central Appalachian basin coal regions: U.S. Geological Survey Professional Paper 1625-C, version 1.0, p. H1-H57, on CD-ROM. (Also available online at $\mathrm{http}: / /$ pubs.usgs.gov/ $\mathrm{pp} / \mathrm{p} 1625 \mathrm{c} / \mathrm{CHAPTER}$ H/CHAPTER_H.pdf.)

Milici, R.C., Freeman, P.A., Carlton, R.W., Bragg, L.J., Butler, D.T., and Tewalt, S.J., 2001, Chapter E-Geology and geochemistry of the Middle Pennsylvanian Lower Kittanning coal bed, Allegheny Group, northern Appalachian basin coal region, in Northern and Central Appalachian Basin Coal Regions Assessment Team, 2000 resource assessment of selected coal beds and zones in the northern and central Appalachian basin coal regions: U.S. Geological Survey Professional Paper 1625-C, version 1.0, p. E1-E67, on CD-ROM. (Also available online at http://pubs.usgs.gov/pp/ p1625c/CHAPTER_E/CHAPTER_E.pdf.)
Milici, R.C., and Gathright, T.M., II, 1985, Geologic features related to coal mine roof falls-A guide for miner training: Virginia Division of Mineral Resources Publication 55, $13 \mathrm{p}$.

Milici, R.C., Gathright, T.M., II, Miller, B.W., Gwin, M.R., and Stanley, C.B., 1982, Geologic factors related to coal mine roof falls in Wise County, Virginia: report prepared by the Virginia Division of Mineral Resources for the Appalachian Regional Commission under contract CO-7232-80-I-302-0206, 103 p.

Milici, R.C., Gathright, T.M., II, Miller, B.W., Gwin, M.R., and Stanley, C.B., 1986, Subtle bedding plane faults-A major factor contributing to coal mine roof falls in southwestern Virginia, in McDowell, R.C., and Glover, Lynn, III, eds., The Lowry volume-Studies in Appalachian geology: Virginia Polytechnic Institute and State University Department of Geological Sciences Memoir 3, p. 83-95.

Milici, R.C., and Hatch, J.R., 2004, Assessment of undiscovered Carboniferous coal-bed gas resources of the Appalachian Basin and Black Warrior Basin Provinces, 2002: U.S. Geological Survey Fact Sheet 2004-3092, 2 p. (Also available online at http://pubs.usgs.gov/fs/2004/3092/.)

Milici, R.C., Ryder, R.T., Swezey, C.S., Charpentier, R.R., Cook, T.A., Crovelli, R.A., Klett, T.R., Pollastro, R.M., and Schenk, C.J. (all of the U.S. Geological Survey, Appalachian Basin Province Assessment Team), 2003, Assessment of undiscovered oil and gas resources of the Appalachian Basin Province, 2002: U.S. Geological Survey Fact Sheet FS-009-03, 2 p. (Also available online at http://pubs.usgs. gov/fs/fs-009-03/.)

Miller, R.L., 1969, Pennsylvanian formations of southwest Virginia: U.S. Geological Survey Bulletin 1280, 62 p.

Morse, W.C., 1931, The Pennsylvanian invertebrate fauna [of Kentucky], in The paleontology of Kentucky: Kentucky Geological Survey, ser. 6, [Geologic Report,] v. 36, p. 293-348, pls. $45-54$.

Nickelsen, R.P., 1979, Sequence of structural stages of the Alleghany orogeny, at the Bear Valley strip mine, Shamokin, Pennsylvania: American Journal of Science, v. 279, no. 3, p. 225-271.

Nolde, J.E., 1994a, Devonian to Pennsylvanian stratigraphy and coal beds of the Appalachian Plateaus province, in Geology and mineral resources of the southwest Virginia coalfield: Virginia Division of Mineral Resources Publication 131, p. 1-85.

Nolde, J.E., 1994b, Coal beds, coal zones, and key stratigraphic names in the Pennsylvanian units of southwestern Virginia: Virginia Division of Mineral Resources Publication 136,1 sheet. 
Nolde, J.E., 1995, Coalbed methane in Virginia: Virginia Minerals, v. 41 , no. 1, p. $1-7$.

Nolde, J.E., and Spears, David, 1998, A preliminary assessment of in place coalbed methane resources in the Virginia portion of the central Appalachian basin: International Journal of Coal Geology, v. 38, no. 1-2, p. 115-136.

Northern and Central Appalachian Basin Coal Regions Assessment Team, 2001, 2000 resource assessment of selected coal beds and zones in the northern and central Appalachian basin coal regions: U.S. Geological Survey Professional Paper 1625-C, version 1.0, on 2 CD-ROMs. (Contains 10 chapters lettered $\mathrm{A}-\mathrm{J}$, some of which are cited herein by author.) (Version 1.01 is available online at http://pubs.usgs. gov/pp/p1625c/.)

Pashin, J.C., and Groshong, R.H., Jr., 1998, Structural control of coalbed methane production in Alabama: International Journal of Coal Geology, v. 38, no. 1-2, p. 89-113.

Pashin, J.C., and Hinkle, Frank, 1997, Coalbed methane in Alabama: Geological Survey of Alabama Circular 192, $71 \mathrm{p}$.

Patchen, D.G., Schwietering, J.F., Avary, K.L., and Repine, T.E., 1991, Coalbed gas production, Big Run and Pine Grove fields, Wetzel County, West Virginia: West Virginia Geological and Economic Survey Publication C-44, 33 p.

Pennsylvania Bureau of Topographic and Geologic Survey, 2014, Pennsylvania coalbed methane wells database: Pennsylvania Bureau of Topographic and Geologic Survey database accessed on May 14, 2014, at http:/www.dcnr. state.pa.us/topogeo/econresource/cbm/cbm_stats/index.htm.

Puglio, D.G., and Iannacchione, A.T., 1979, Geology, mining, and methane content of the Freeport and Kittanning coalbeds in Indiana and surrounding counties, Pa.: U.S. Bureau of Mines Report of Investigations 8406, 35 p. (Also available online at http://www.cdc.gov/niosh/mining/UserFiles/ works/pdfs/ri8406.pdf.)

Rice, C.L., 1986, Pennsylvanian System, in McDowell, R.C., ed., The geology of Kentucky - A text to accompany the Geologic Map of Kentucky: U.S. Geological Survey Professional Paper 1151-H, p. H31-H44.

Rice, C.L., Sable, E.G., Dever, G.R., Jr., and Kehn, T.M., 1979, The Mississippian and Pennsylvanian (Carboniferous) Systems in the United States-Kentucky: U.S. Geological Survey Professional Paper 1110-F, p. F1-F32.

Rice, D.D., and Finn, T.M., 1996, Coalbed gas plays, in Appalachian Basin Province (067), in Coal-bed gas play summary, in Gautier, D.L., Dolton, G.L., Takahashi, K.I., and Varnes, K.L., eds., 1995 national assessment of United States oil and gas resources_-Results, methodology, and supporting data: U.S. Geological Survey Digital Data Series
DDS-30, release 2, 1 CD-ROM. (Also available online at http://certmapper.cr.usgs.gov/data/noga95/prov67/text/ prov67.pdf; scroll down to page 64. Accessed May 21, 2014.)

Rodgers, John, 1949, Evolution of thought on structure of middle and southern Appalachians: American Association of Petroleum Geologists Bulletin, v. 33, no. 10, p. 1643-1654.

Rodgers, John, 1970, The tectonics of the Appalachians: New York, Wiley-Interscience, 271 p.

Roen, J.B., and Walker, B.J., eds., 1996, The atlas of major Appalachian gas plays: West Virginia Geological and Economic Survey Publication Volume V-25, 201 p.

Ruppert, L.F., Tewalt, S.J., Wallack, R.N., Bragg, L.J., Brezinski, D.K., Carlton, R.W., Butler, D.T., and Calef, F.J., III, 2001, Chapter D-A digital resource model of the Middle Pennsylvanian Upper Freeport coal bed, Allegheny Group, northern Appalachian basin coal region, in Northern and Central Appalachian Basin Coal Regions Assessment Team, 2000 resource assessment of selected coal beds and zones in the northern and central Appalachian basin coal regions: U.S. Geological Survey Professional Paper 1625-C, version 1.0, p. D1-D97, on CD-ROM. (Also available online at http://pubs.usgs.gov/pp/p1625c/CHAPTER_D/ CHAPTER_D.pdf.)

Schruben, P.G., Arndt, R.E., and Bawiec, W.J., 1994, Geology of the conterminous United States at 1:2,500,000 scale-A digital representation of the 1974 P.B. King and H.M. Beikman map, with display software by R.A. Ambroziak: U.S. Geological Survey Digital Data Series DDS-11 [release 1], one CD-ROM. (Release 1 was superseded in 1998 by release 2, which is available online at http://pubs.usgs.gov/ dds/dds11/.)

Schultz, A.P., 1986, Broken formations of the Pulaski thrust sheet near Pulaski, Virginia, in McDowell, R.C., and Glover, Lynn, III, eds., The Lowry volume-Studies in Appalachian geology: Virginia Polytechnic Institute and State University Department of Geological Sciences Memoir 3, p. 13-26.

Schultz, A.P., 1988, Horses in fensters of the Pulaski thrust sheet, southwestern Virginia; Structure, kinematics, and implications for hydrocarbon potential of the eastern overthrust belt, chap. A of Evolution of sedimentary basinsAppalachian basin: U.S. Geological Survey Bulletin 1839, p. A1-A13.

Slucher, E.R., and McDonald, James, 2004, Coalbed methane development in Ohio [abs.]: AAPG Eastern Section meeting, October 3-5, 2004, Columbus, Ohio, Program with Abstracts, p. 124-125. (Also available online at http:// www.searchanddiscovery.com/abstracts/html/2004/eastern/ slucher.htm.) 
Stanley, C.B., and Schultz, A.P., 1983, Coal-bed methane resource evaluation, Montgomery County, Virginia: Virginia Division of Mineral Resources Publication 46, 59 p.

Swartz, C.K., Baker, W.A., Jr., Watts, A.S., Schurecht, H.G., and Mathews, E.B., 1922, Part I, Second report on the coals of Maryland; Part 2, The fire clays of Maryland: Maryland Geological Survey [Reports], v. XI, 549 p., 11 pls.

Tewalt, S.J., Ruppert, L.F., Bragg, L.J., Carlton, R.W., Brezinski, D.K., Wallack, R.N., and Butler, D.T., 2001, Chapter C-A digital resource model of the Upper Pennsylvanian Pittsburgh coal bed, Monongahela Group, northern Appalachian basin coal region, in Northern and Central Appalachian Basin Coal Regions Assessment Team, 2000 resource assessment of selected coal beds and zones in the northern and central Appalachian basin coal regions: U.S. Geological Survey Professional Paper 1625-C, version 1.0, p. C1-C102, on CD-ROM. (Also available online at http:// pubs.usgs.gov/pp/p1625c/CHAPTER_C/CHAPTER_C. pdf.)

Tewalt, S.J., Ruppert, L.F., Bragg, L.J., Weisenfluh, G.A., Thacker, E.E., Sites, R.S., Blake, B.M., Jr., Freeman, P.A., Bryant, L.C., and Butler, D.T., 2001, Chapter F-A digital resource model of the Middle Pennsylvanian Fire Clay coal zone, Pottsville Group, central Appalachian basin coal region, in Northern and Central Appalachian Basin Coal Regions Assessment Team, 2000 resource assessment of selected coal beds and zones in the northern and central Appalachian basin coal regions: U.S. Geological Survey Professional Paper 1625-C, version 1.0, p. F1-F72, on CD-ROM. (Also available online at http://pubs.usgs.gov/pp/ p1625c/CHAPTER_F/CHAPTER_F.pdf.)

Trevits, M.A., Lambert, S.W., Steidl, P.F., and Elder, C.H., 1988, Methane drainage through small diameter vertical boreholes, chap. 9 of Deul, Maurice, and Kim, A.G., eds., Methane control research; Summary of results, 1964-80: U.S. Bureau of Mines Bulletin 687, p. 106-127.

U.S. Geological Survey Geologic Names Committee, 2007, Divisions of geologic time-Major chronostratigraphic and geochronologic units: U.S. Geological Survey Fact Sheet 2007-3015, 2 p. (Also available online at http://pubs.usgs. gov/fs/2007/3015/.)

Virginia Center for Coal and Energy Research, 2004, Virginia energy patterns and trends - Coal bed methane production by county: Blacksburg, Va., Virginia Center for Coal and Energy Research Web site at http://www.energy.vt.edu/vept/ naturalgas/gas_county.asp. (Accessed in 2004.)

Virginia Division of Gas and Oil [2007], Gas and oil production statistics [for 1999-2006 by county or operator]: Virginia Division of Gas and Oil Web site at http://www. dmme.virginia.gov/DGO/Production/gasoilproductionstats. shtml. (Accessed June 11, 2008. Production statistics are now available at http://www.dmme.virginia.gov/dgoinquiry/ frmmain.aspx, accessed May 21, 2014.)

Virginia Division of Mineral Resources, 1993, Geologic map of Virginia and expanded explanation: [Charlottesville, Va.,] Virginia Division of Mineral Resources, 1 map, scale, 1:500,000, and 80-p. booklet.

Wandrey, C.J., 2004, Bombay Geologic Province Eocene to Miocene Composite Total Petroleum System, India, chap. F of Wandrey, C.J., ed., Petroleum systems and related geologic studies in Region 8, South Asia: U.S. Geological Survey Bulletin 2208, 20 p., available only online at http:// pubs.usgs.gov/bul/2208/F/.

West Virginia Geological and Economic Survey, 2006, Coalbed methane wells reported to WVGES: Morgantown, W. Va., West Virginia Geological and Economic Survey table available online at http://www.wvgs.wvnet.edu/www/datastat/ $\mathrm{cbm} / \mathrm{dtcmdn} 90 . \mathrm{htm}$

White, David, 1900, The stratigraphic succession of the fossil floras of the Pottsville formation in the southern anthracite coal field, Pa.: U.S. Geological Survey Annual Report 20 (1898-99), pt. 2, p. 749-930.

Wilson, C.W., Jr., 1949, Pre-Chattanooga stratigraphy in central Tennessee: Tennessee Division of Geology Bulletin 56, $407 \mathrm{p}$.

Wolfe, M.E., 1997, Coalbed methane-An untapped energy resource in Ohio: Ohio Geology, Summer 1977, p. 4. Also available at http://geosurvey.ohiodnr.gov/portals/geosurvey/ PDFs/Newsletter/Summer97.pdf, accessed June 18, 2014.)

Wood, G.H., Jr., 1972, Geologic map of anthracite-bearing rocks in the Pottsville quadrangle, Schuylkill County, Pennsylvania: U.S. Geological Survey Miscellaneous Geologic Investigations Map I-681, 2 sheets, scale 1:12,000.

Wood, G.H., Jr., and Arndt, H.H., 1973, Geologic map of the Delano quadrangle, Schuylkill County, Pennsylvania: U.S. Geological Survey Geologic Quadrangle Map GQ-1054, scale 1:24,000.

Wood, G.H., Jr., Arndt, H.H., Soren, Julian, Trexler, J.P., and Yelenosky, Andrew, 1956, Subdivision of the Pottsville Formation in southern anthracite field, Pennsylvania: American Association of Petroleum Geologists Bulletin, v. 40, no. 11, p. 2669-2688.

Wood, G.H., Jr., and Bergin, M.J., 1970, The Valley and Ridge and Appalachian Plateau; Structure and tectonics; Structural controls of the anthracite region, Pennsylvania, in Fisher, G.W., Pettijohn, F.J., Reed, J.C., Jr., and Weaver, K.N., eds., Studies of Appalachian geology - Central and southern: New York, Wiley Interscience, p. 147-160.

Wood, G.H., Jr., Kehn, T.M., Carter, M.D., and Culbertson, W.C., 1983, Coal resource classification system of the U.S. 
Geological Survey: U.S. Geological Survey Circular 891, 65 p. (Also available online at http://pubs.usgs.gov/circ/ c891/.)

Wood, G.H., Jr., Kehn, T.M., and Eggleston, J.R., 1986, Depositional and structural history of the Pennsylvania anthracite region, in Lyons, P.C., and Rice, C.L, eds., Paleoenvironmental and tectonic controls in coal-forming basins of the United States: Geological Society of America Special Paper 210, p. 31-47.

Wood, G.H., Jr., and Trexler, J.P., 1968, Geologic maps of anthracite-bearing rocks in the west-central part of the southern anthracite field, Pennsylvania, western area: U.S. Geological Survey Miscellaneous Geologic Investigations Map I-529, 4 sheets, scale 1:12,000.

Wood, G.H., Jr., Trexler, J.P., and Arndt, H.H., 1962, Pennsylvanian rocks of the southern part of the anthracite region of eastern Pennsylvania, in Short papers in geology and hydrology, articles 60-119, chap. C of Geological Survey research 1962: U.S. Geological Survey Professional Paper 450, p. C39-C42.

Wood, G.H., Jr., Trexler, J.P., and Kehn, T.M., 1968, Geological maps of anthracite-bearing rocks in the west-central part of the southern anthracite field, Pennsylvania, eastern area: U.S. Geological Survey Miscellaneous Geologic Investigations Map I-528, 6 sheets (4 map sheets and 2 sheets of structure sections), scale 1:12,000.

Wood, G.H., Jr., Trexler, J.P., and Kehn, T.M., 1969, Geology of the west-central part of the southern anthracite field and adjoining areas, Pennsylvania: U.S. Geological Survey Professional Paper 602, 150 p.

Young, D.M., 1957, Deep drilling through Cumberland overthrust block in southwestern Virginia: American Association of Petroleum Geologists Bulletin, v. 41, no. 11, p. 2567-2573. 


\section{Glossary}

[Many coal-related definitions below are derived from U.S. Geological Survey (USGS) Circular 891 (Wood and others, 1983); see http://pubs.usgs.gov/circ/c891/glossary.htm]

anthracite A rank class of nonagglomerating coals defined by the American Society for Testing and Materials as having more than 86 percent fixed carbon and less than 14 percent volatile matter on a dry, mineral-matter-free basis. This class of coal is divisible into the semianthracite, anthracite, and meta-anthracite groups on the basis of increasing fixed carbon and decreasing volatile matter.

ash The inorganic residue remaining after complete incineration of coal. The ash yielded by incineration generally has been changed in weight and composition from the inorganic matter in the coal.

ash-free basis A theoretical analysis calculated from basic analytical data about a coal sample and expressed as if the total ash had been removed.

assessment unit (AU) A term used by the USGS in petroleum resource assessments for a subdivision of a total petroleum system. Assessment units are defined to be more closely associated with the generation and migration of petroleum than are plays. According to Wandrey (2004, p. iii):

An assessment unit is a mappable part of a total petroleum system in which discovered and undiscovered fields constitute a single, relatively homogenous population such that the chosen methodology of resource assessment based on estimation of the number and sizes of undiscovered fields is applicable.

See total petroleum system.

bench A subdivision and (or) layer of a coal bed separated from other layers by partings of noncoal rock.

bituminous coal A rank class of coals as defined by the American Society for Testing and Materials that is high in carbonaceous matter, has less than 86 percent fixed carbon, has more than 14 percent volatile matter on a dry, mineral-matter-free basis, and has a calorific value of more than 10,500 Btu per pound on a moist, mineral-matter-free basis. This class may be either agglomerating or nonagglomerating and is divisible into the high-volatile C, B, A; medium-volatile; and low-volatile bituminous coal groups on the basis of increasing calorific value and fixedcarbon content and decreasing volatile matter.

British thermal unit (Btu) The quantity of heat required to raise the temperature of 1 pound of water 1 degree Fahrenheit $\left(1^{\circ} \mathrm{F}\right)$ at, or near, its point of maximum density at $39.1^{\circ} \mathrm{F}$ (equivalent to 251.995 gram calories; 1,054.35 joules; 1.05435 kilojoules; 0.25199 kilocalorie).

calorie (cal) The quantity of heat required to raise the temperature of 1 gram of water from 15 degrees to 16 degrees Celsius $\left(15^{\circ} \mathrm{C}\right.$ to $16^{\circ} \mathrm{C}$ ). A calorie is also termed gram calorie or small calorie (equivalent to 0.00396832 Btu; 4.184 joules; 0.001 kilogram calorie).

calorific value The amount of heat obtainable by combustion of coal under set conditions. Can be expressed in British thermal units per pound, kilojoules per kilogram, or calories per gram. Also called "heating value."

coal A readily combustible rock containing more than 50 percent by weight and more than 70 percent by volume of carbonaceous material, including inherent moisture. It is formed from plant remains that have been compacted, indurated, chemically altered, and metamorphosed by heat and pressure during geologic time.

coal bed All the coal and partings lying between a roof and floor. The terms "seam" and "vein" should not be used in USGS reports. In this report, the term "coal bed" consists of two words except in the term "coalbed methane."

coalbed methane (CBM) Methane gas commonly generated from and contained in coal beds. 
coal field A discrete area underlain by strata containing one or more coal beds.

coal-mine methane (CMM) The part of the coalbed methane released from coal beds before, during, and after mining. Some CMM is recovered and used as a resource, and some is emitted to the atmosphere and is a greenhouse gas.

coal region An area containing one or more coal fields.

coal zone A series of laterally extensive and (or) lenticular coal beds and associated strata that arbitrarily can be viewed as a unit. Generally, the coal beds in a coal zone are assigned to the same geologic member or formation.

continuous accumulation An unconventional hydrocarbon accumulation that is not trapped in the conventional sense because the accumulation lacks a downdip water-hydrocarbon contact. These accumulations occupy large areas and are termed continuous because the reservoir rock is charged with oil or gas throughout.

dry, mineral-matter-free basis A type of calculated analytical value of a coal sample expressed as if the total moisture and mineral matter had been removed. "Mineral-matterfree basis" is not the same as "ash-free basis."

fixed carbon The solid residue, other than ash, obtained by destructive distillation of a coal, determined by definite prescribed methods.

floor Stratigraphically, the rock immediately underlying a coal bed. Where the bed is overturned, the stratigraphic floor is the mining roof.

gob Coal-mining waste or geologic material that has settled into former coal mines.

gob gas Gas recovered from gob.

heating value See calorific value.

high-volatile bituminous coal Three related rank groups of bituminous coal as defined by the American Society for Testing and Materials, which collectively contain less than 69 percent fixed carbon on a dry, mineral-matterfree basis; more than 31 percent volatile matter on a dry, mineral-matter-free basis; and a calorific value of more than 10,500 Btu per pound on a moist, mineral-matter-free basis.

lignite A class of brownish-black, low-rank coal defined by the American Society for Testing and Materials as having less than 8,300
Btu per pound on a moist, mineral-matter-free basis. In the United States, lignite is separated into two groups: lignite A $(6,300$ to 8,300 Btu per pound) and lignite B $(<6,300$ Btu per pound).

low-volatile bituminous coal A rank group of bituminous coal as defined by the American Society for Testing and Materials, which contains more than 78 percent and less than 86 percent fixed carbon, and more than 14 percent and less than 22 percent volatile matter on a dry, mineral-matter-free basis.

Ma (mega-annum) Age in millions of years before present (before A.D. 1950).

medium-volatile bituminous coal A rank group of bituminous coal as defined by the American Society for Testing and Materials, which contains more than 69 percent and less than 78 percent fixed carbon and more than 22 percent and less than 31 percent volatile matter on a dry, mineral-matter-free basis.

mineral matter The solid inorganic material in coal.

mineral-matter-free basis A theoretical analysis calculated from basic analytical data and expressed as if the total mineral matter had been removed. Used in determining the rank of a coal.

minimum petroleum system (MPS) A term used by the USGS in petroleum resource assessments. According to Wandrey (2004, p. iii):

The minimum petroleum system is that part of a total petroleum system encompassing discovered shows and accumulations along with the geologic space in which the various essential elements have been proved by these discoveries.

See total petroleum system.

mining All methods of obtaining coal or its byproducts from the Earth's crust, including underground, surface, and in situ mining.

moist, mineral-matter-free basis A theoretical analysis calculated from basic analytical data and expressed as if the mineral matter had been removed and the natural moisture retained. Used in determining the rank of coal.

moisture content The percentage of moisture (water) in coal. Two types of moisture are found in coal, namely, free or surface mois- 
ture removed by exposure to air, and inherent moisture entrapped in the coal and removed by heating to $220^{\circ} \mathrm{F}$.

parting A layer or stratum of noncoal material in a coal bed that does not exceed the thickness of coal in either of the directly underlying or overlying benches.

rank The classification of coals according to their degree of metamorphism, progressive alteration, or coalification (maturation) in the natural series from lignite to anthracite. Classification is made on the basis of analysis of coal. The rank of coal can be used to infer the approximate dry, mineral-matter-free calorific value, fixed carbon, and volatile matter in a coal, because the amounts of the constituents vary little within each coal rank. The ranks are listed below (from Wood and others, 1983, table 1):

\section{Anthracite \\ Meta-anthracite \\ Anthracite \\ Semianthracite \\ Bituminous coal}

Low-volatile bituminous coal

Medium-volatile bituminous coal

High-volatile A bituminous coal

High-volatile $\mathrm{B}$ bituminous coal

High-volatile $\mathrm{C}$ bituminous coal

Subbituminous coal

Subbituminous A coal

Subbituminous B coal

Subbituminous C coal

\section{Lignite}

Lignite A

Lignite B

roof Stratigraphically, in underground mining, the rock immediately overlying a coal bed. Where a bed is overturned, the stratigraphic roof is the mining floor. total petroleum system (TPS) A term used by the USGS (Magoon, 1988) in petroleum resource assessments. A geologic province may contain more than one TPS. A TPS may contain assessment units. According to Wandrey (2004, p. iii):

The total petroleum system includes all genetically related petroleum that occurs in shows and accumulations (discovered and undiscovered) that (1) has been generated by a pod or by closely related pods of mature source rock, and (2) exists within a limited mappable geologic space, along with the other essential mappable geologic elements (reservoir, seal, and overburden rocks) that control the fundamental processes of generation, expulsion, migration, entrapment, and preservation of petroleum.

See minimum petroleum system.

vitrinite An organic component of coal that looks shiny like glass (vitreous). Vitrinite formed by the thermal alteration of lignin and cellulose in the cell walls of land plants.

vitrinite reflectance An indicator of temperatures that have affected organic material in coal and rocks and, thus, an indicator of (1) coal rank or (2) thermal maturity and the possibility of petroleum generation. Vitrinite reflectance $\left(R_{o}\right)$ is a measurement of the percentage of light reflected from a vitrinite grain at high magnification; values are expressed as percent vitrinite reflectance, or $\% \mathrm{R}_{0}$.

volatile matter In coal, those products, exclusive of moisture, given off as gas and vapor and determined by definite methods prescribed by the American Society for Testing and Materials. 